\title{
FORLSTRY FOR WOODMEN
}

\section{HANSON}

OKRORD

AT TRE COARENDON PRESS 


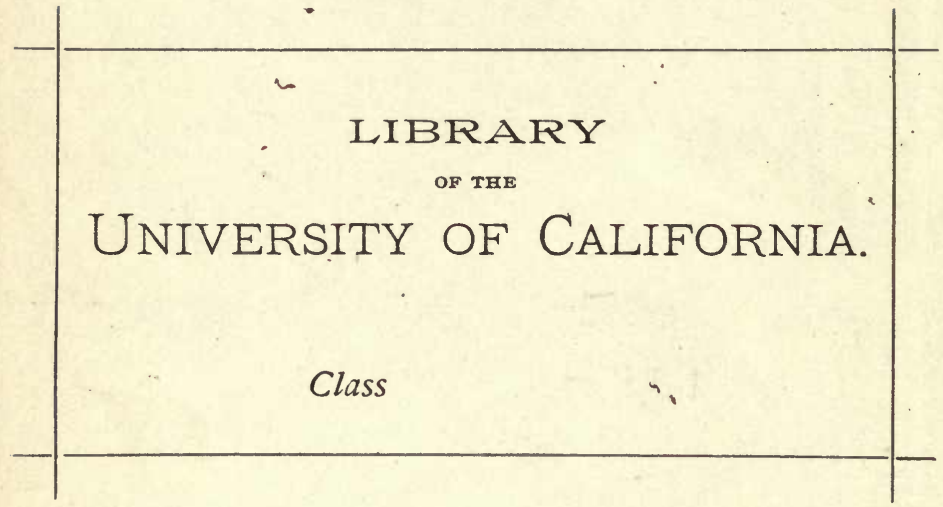






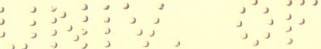

$\because:$ 


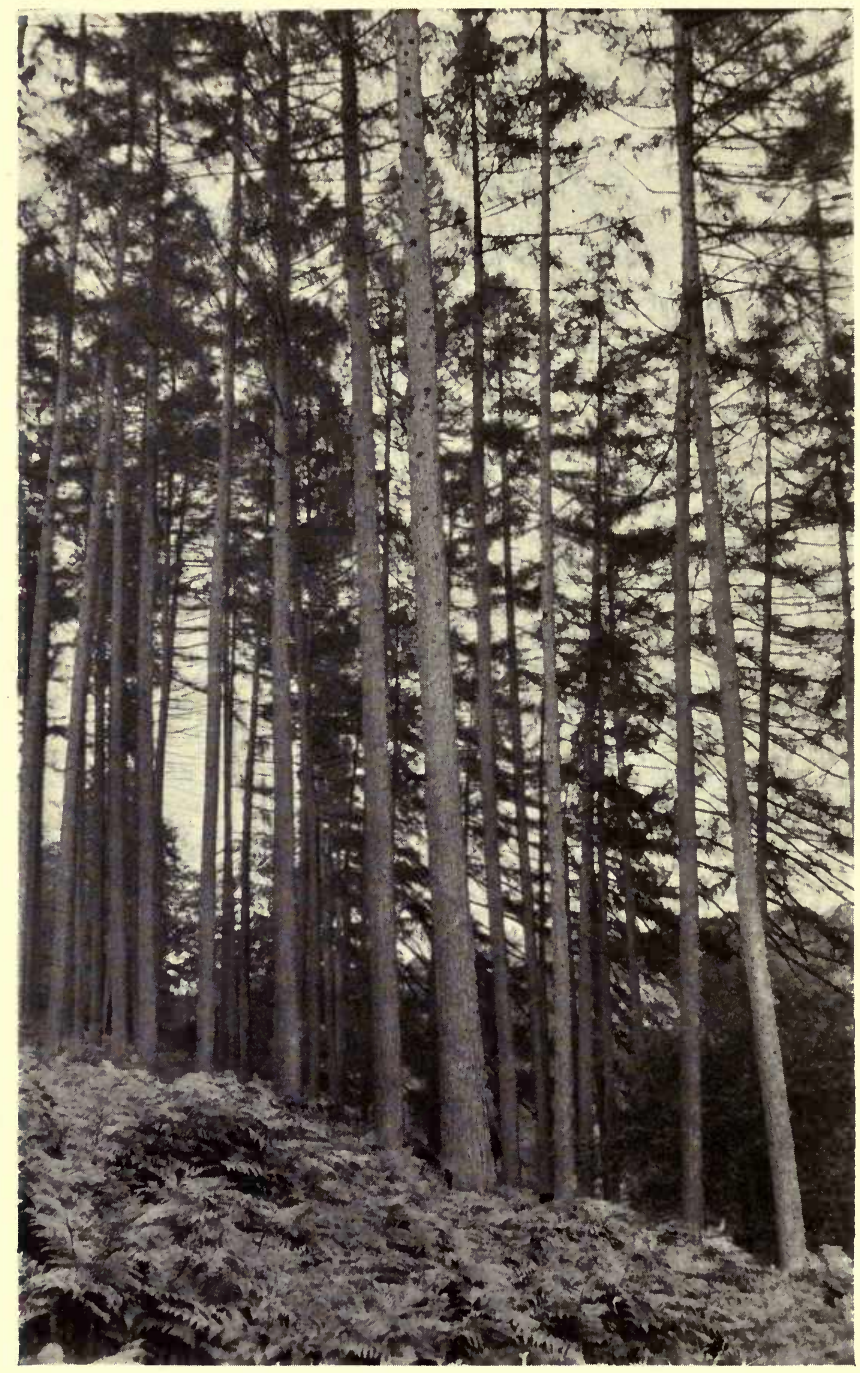

Larch at Walcot. Aged 124 years. Height of tallest tree I45 feet. Average volume 77 cubic feet. Photograph by M. C. Duchesne. From the Quarterly' Journal of Forestry. 


\section{FORESTRY FOR}

\section{WOODMEN}

BY

\section{O. HANSON}

FORMERLY DEPUTY CONSERVATOR OF FORESTS, INDIAN FOREST DEPARTMENT NOW INSTRUCTOR, THE CROWN SCHOOL OF FORESTRY FOR WOODMEN, ROYAL FOREST OF DEAN

\section{OXFORD}

AT THE CLARENDON PRESS 


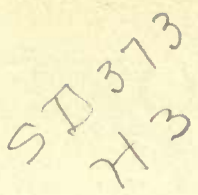

HENRY FROWDE

PUBLISHER TO THE UNIVERSITY OF OXFORD

LONDON, EDINBURGH, NEW YORK TORONTO AND MELBOURNE

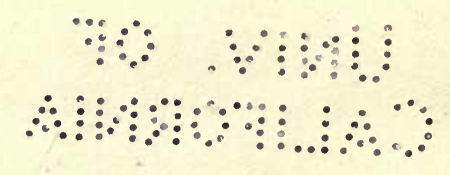




\section{PREFACE}

THIs book is, by permission, based on Schlich's Manual of Forestry. It has been written to supply a cheap book on scientific forestry for foresters and woodmen, few of whom can afford the more expensive works, and was at first drawn up for the use of the School of Forestry for Working Men in the Forest of Dean. I am greatly indebted to Sir William Schlich, K.C.I.E., F.R.S., Professor of Forestry in the University of Oxford, and to the late Mr. W. R. Fisher, under whom I studied the subject while at Cooper's Hill College, for giving me permission to make use of the Manual of Forestry and to reproduce some of the illustrations from that work. I have also referred in Chapter I to Gifford Pinchot's A Primer of Forestry, and to Bridges's and Dicks's Plant Study; I have occasionally referred to Nisbet's The Forester, Forbes's English Estate Forestry, Simpson's The New Forestry and The Estate Nursery. The part on hedges is indebted to Malden's Hedges and Hedgemaking. Most of the photographs were taken by myself; some are by Mr. R. C. Milward or Mr. M. C. Duchesne, who have kindly allowed me to reproduce them. The other illustrations are from Schlich's Manual. My 
thanks are due to $\mathrm{Mr}$ E.P. Popert, Consulting Forester to the Commissioners of Woods and Forests, and to Mr. A. G. Hobart-Hampden, Agent to the Earl of Buckinghamshire, both retired Conservators of the Indian Forest Department, for reading through the manuscript and for much valuable advice and help in its preparation, and to Professor J. Bretland Farmer for revising the botanical part of the book.

\section{O. Hanson.}

Latimer Lodge, Cinderford. 


\section{CONTENTS}

CHAP.

PAGE

I. The life History of a Tree . • . . • . 7

II. Tree Growth in relation to Climate and Soll . i 8

III. Pure and Mixed Woods . . . . . . 36

IV. Nursery Management . . . . . . . 47

V. Sowing and Planting in the Forest . • . 60

VI. Tending of Woods . . . . . . . . • 73

VII. Methods of Treatment (including natural regenera-

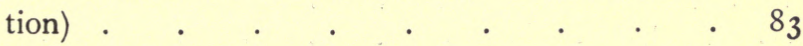

VIII. Protection of Woods against Destructive Animals, Birds, and Insects . . . . . 108

IX. Protection of Woods against Weeds and Fungi . 125

X. Protection of Woods against Frost, Drought, Storms, AND Fires

XI. Sylvicultural Notes on Broad-leaved Trees . ${ }^{4} 8$

XII. Sylvicultural Notes on Conifers . . . $\quad$ i 64

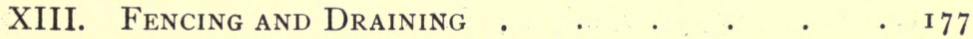

XiV. Felling and Measurement of Timber . . . 187

XV. Working Plans . . . . . . . . . 204

XVI. The Uses of British Timber . . . . . 216 


\section{LIST OF ILLUSTRATIONS}

FIG.

PAGE

I. The cockchafer . . . . . . . . . . II5

2. The pine weevil . . . . . . . . . . . . . . 116

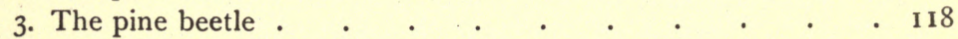

4. The oak-leaf roller moth . . . . . . . . . . 119

5. The larch miner moth . . . . . . . . 120

6. Pine sawfly caterpillars . . . . . . . . . . I2I

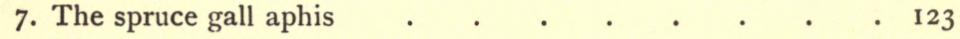

8. The larch aphis . . . . . . . . . . . . . . . $\quad . \quad 123$

9. The honey fungus . . . . . . . . . . 129

Io. The red-rot root-fungus $. \quad . \quad . \quad . \quad . \quad . \quad . \quad$. 13 I

II. Pine blister . . . . . . . . . . . I32

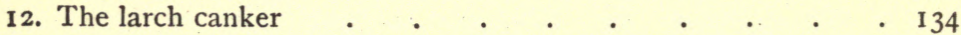

13. Canker caused by Nectria ditissima . . . . . . 136

14. Weise's hypsometer . . . . . . . . . 195

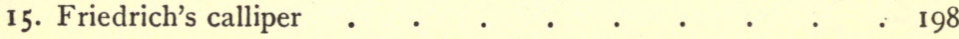

Plate.

I. Larch at Walcot . . . . . . . Frontispiece

II. Oak and beech planted $189 \mathrm{I}$ in alternate lines facing $p . \quad 40$

III. Oak aged 37 years, with natural beech underwood ", 42

IV. Oak aged 50 years, height 43 feet . . . . " 46

V. Oak aged 95 years, height 40 feet . . . . . , 80

VI. Natural regeneration of oak aged about 8 years . , , $\quad 92$

VII. Beech planted I89I at $4 \mathrm{ft}$. by $4 \mathrm{ft}$. . . . , , I 50

VIII. Hornbeam planted I89I at $4 \mathrm{ft}$. by $4 \mathrm{ft}$. . . " , I 54

IX. Oak and larch with coppiced beech . . . " , 156

X. Douglas fir planted $\mathrm{I} 893$ at $4 \mathrm{ft}$ by $4 \mathrm{ft}$. . . „ , $\quad$ I66

XI. Larch planted $\mathrm{I} 89 \mathrm{I}$ at $4 \mathrm{ft}$. by $4 \mathrm{ft}$. . . . , , 168

XII. Mature spruce at Walcot . . . . . , , 174 


\section{CHAPTER I}

\section{THE LIFE HISTORY OF A TREE}

SYLVICULTURE means the cultivation of trees in masses such as are found in woods or forests, and is not the same as arboriculture, which means the cultivation of single trees as they occur in parks and gardens. The object of arboriculture is usually to produce a beautiful tree which will be an ornament to the place where it grows. The object of forestry or sylviculture is usually to produce the largest amount of the best quality of timber which it is possible to grow on a given area of land.

Before commencing the study of forestry it is necessary to know something about the life history of the trees which make up the forest. A tree is a woody plant growing up from the ground usually with a single stem. It consists of three parts. First, the Root, which grows downwards into the earth to a depth of three or four feet, and binds the tree to the soil; it takes in water and certain mineral matters which are dissolved in it, and which are needed by the tree in its growth. Second, the Stem, Trunk, or Bole, which supports the crown, and through which the water and its dissolved matters go up from the roots to the leaves. Third, the Crown, consisting of branches, twigs, buds, leaves, and flowers. In the leaves all the food material is worked up and, as it were, digested.

The bole is the most important part to the woodman, as almost the whole value lies in this part of the tree; nevertheless to get the bole into a proper shape the woodman devotes most of his attention to the crown, because its size and shape 
are more easily regulated and, as will be seen later, by manipulating the crown the woodman can cause the bole to grow into the shape he desires.

In a forest the crowns of the trees form a cover over the ground, and this cover is called the leaf-canopy.

The food of a tree. The youngest roots are covered with fine root hairs which take in water, and minerals (including compounds containing nitrogen) dissolved in it, from the soil. The water passes up the stem into the leaves, and these take in from the air carbon dioxide gas, which dissolves in the water contained in the leaves of the plant. The leaves, and often other parts of the tree, contain a green coloured matter called chlorophyll, which has the remarkable power of being able to cause the elements provided by water and carbon dioxide to become united into complex carbon compounds which form a large part of the actual food of the tree. The principal substances thus formed are known as carbohydrates, and of them sugar is the most important. There are several different kinds of sugar, but sugar of some sort is the chief body to arise in consequence of the activity of chlorophyll. Sunlight, a suitable temperature, and the presence of a trace of iron salt are all essential for the process ; indeed, chlorophyll itself is not formed unless at least these three conditions are complied with. It does not, however, need so bright a light for its own production as is demanded for the synthesis (or formation) of the sugars. The latter process, being dependent on light, is generally spoken of as Photosynthesis, and it is one of the most important of the activities of green plants.

When sugar is produced in a leaf faster than it can be removed to other parts of the plant, of course its concentration in the cell sap rises. If this were allowed to go on, its further production would soon be arrested. But this stoppage is prevented by the fact that when the concentration reaches a certain point, new activities of the protoplasm of the living cell are awakened, and the formation of insoluble starch at 
the expense of the sugar begins. As the starch is insoluble the action of photosynthesis can continue unchecked, seeing that the concentration of the sugar will not rise beyond the critical point. Sugars, as they arise, are also continually passing away from the leaf to other parts of the tree, there to be used up, along with other materials, in the formation of new living substance, wood and other materials, as well as to supply the chemical energy needed for vital processes. The sugar thus translocated may also accumulate in other parts of the tree, and, by stimulating the production of starch in those regions, e.g. in the medullary rays or silver grain of the wood, provide reserve stores of carbohydrate to be drawn on as occasion may arise. When the photosynthetic activity of the leaf ceases, e.g. at night time, the starch formerly produced in the leaves is reconverted, by special ferments, into sugar, which thus continues to replace that which is being still withdrawn from the leaves till all the starch may be finally removed from them. This explains why it is that towards the end of a summer's day the leaves may be full of starch, but next morning may contain little or none.

It must be clearly understood that starch, as such, is of no direct use as a food-it must first be changed into a soluble sugar before it can be employed in the life processes of the plant. The sugar is the utilizable floating capital, the starch the bank reserve, of the plant.

The water from the roots passes upwards to the leaves in the outer layers of the wood, and the sugary sap travels from the leaves to the parts where it is required in the inner layers of the bark. Hence if a tree is 'girdled' by having a ring cut out of it all round the stem, through the bark and outer layers of the wood, it will be killed, as no water can then pass upwards. As a rule, European species are killed by merely cutting through the bark, as the sugary sap cannot then pass downwards to nourish the parts below the ring.

The carbon dioxide gas taken in by the leaves is made up 
of two elements, carbon and oxygen. The leaves keep the carbon and return most of the oxygen to the air, and, as oxygen is the gas we require when we breathe, this process purifies the air from our point of view.

How the tree breathes. All plants, like animals, breathe in air, keeping the oxygen and exhaling the carbon dioxide gas. This process, which is called respiration, is the exact opposite to that of photosynthesis. The difference between the two processes is as follows:-

\section{Photosynthesis.}

I. Is a feeding process.

2. Carbon dioxide gas is retained.

3. Oxygen is returned to the air.

4. Purifies the air.

5. Only takes place in green parts.

6. Only takes place in sunlight.

\section{Respiration.}

I. Is a breathing process.

2. Oxygen is retained.

3. Carbon dioxide gas is returned to the air.

4. Fouls the air.

5. Takes place in all parts.

6. Goes on day and night.

Curious as it may seem, these two processes go on together, but whereas respiration goes on always in all the living parts of the tree, photosynthesis only takes place in green parts and in the day time. During the day photosynthesis is the more active process, and more oxygen is returned to the air than is retained. At night respiration alone is going on. Plants therefore, on the balance, purify the air in the day, and foul it at night, but on the whole the purifying action is much greater than the other.

Under a microscope little openings can be seen through the skin of a leaf, especially on the under surface. These are called stomata, and it is through them that the leaves take in and give out gases. On the bark of the hazel and cherry long slit-like openings are seen; these are also used for breathing purposes, and are called lenticels. They exist on all trees, but are not easily seen on rough barked ones.

Transpiration. Very small quantities of mineral matters are contained in the water coming up from the roots, and 
a large volume of water must therefore pass through the tree in order that it may obtain a sufficient supply of mineral matters. The excess water is evaporated into the air through the stomata, leaving the mineral matters behind. This evaporation from the leaf surface is called transpiration. On a hot day transpiration is rapid, and if at the same time the soil is dry and the roots do not get enough water, the leaves fade. A great deal of power must be required to force the water from the roots up to the top of a tall tree: what this power is cannot be explained exactly, but it is known that there is a considerable pumping action by the roots and also a sucking action due to transpiration from the leaves, and these two forces, especially the latter, may be perhaps the main factors in producing the flow of water up the stem.

The growth of a tree. The tree forms sugar in the way described, and from it, together with the mineral matters, makes new wood and other material. The wood consists of cells which formerly contained protoplasm, the living substance of which plants and animals are essentially composed. Concentric layers of these cells are laid on in the form of a thin coat over the whole tree between the older wood and the bark. The new twigs grow in length by a kind of stretching out from the buds; this stretching only goes on in the first year of the life of the twigs and then ceases, buds being formed from which the next year's twigs shoot out. The older twigs, the branches, and the stem grow in thickness only, and do not increase in length; they grow thicker because new wood is laid on over them each year. Between the wood and the bark there is a very thin layer of living cells called the cambium; this, obtaining nourishment from the sugary sap, increases and grows in thickness, its inner layers giving rise to wood, and its outer layers to bark, while between these two there yet always remains a thin layer of cambium. The multiplication of cells inwards which turn 
into wood is greater than that outwards which turn into bark, and thus the layer of wood formed is much thicker than the layer of bark. In this way each year a new layer of wood is added to the outside of the older wood, and a new layer of bark to the inner side of the old bark. The result of this is that the outer bark gets stretched until it can stretch no more; and then it cracks or peels. Before this stage is reached, however, another layer of cells in the bark is formed, called cork cambium, and this continuously forms cork on the outer side. The whole tree is thus encased in cork, which prevents water getting into the tree when the outer bark cracks. After a time this layer of cork in its turn gets stretched and cracks, and the process is repeated, a new cork cambium is formed behind the old one and makes another layer of cork.

The structure of bark is thus very complicated. What is ordinarily called bark consists of two parts. All that is outside of the latest formed cork is dead matter, because no water or food supply can get to it from the interior of the tree. This is the true bark which serves to protect the tree from outside dangers. It may remain for a long period or it may strip off in patches or rings. All between the cambium and the cork cambium is the inner bark, or bast. This remains alive, and through it the food material passes from the leaves to any part of the tree.

The structure of wood. All wood is made up of very small tubes and cells. In the latest formed wood the tubes act as pipes through which the water flows up the tree. In this part the wood is usually soft and light in colour, and it is known as the sap-wood.

In the centre of the tree the pipes are blocked up and are no longer used for the transit of water. They are, in fact, dead, and they usually become hard and tough. This is the heartwood, which serves to give strength to the stem. The heartwood is not necessary for any vital action, and the tree can 
live without it, as is shown by the fact that hollow trees can live to a great age.

These pipes and cells are of many shapes, and are arranged in many different ways in the several species.

On cutting across the stem of a tree we see the anmual rings. These are formed in the following way: In the spring when the leaves sprout there is a great demand for water, and the pipes and cells which are then formed have thin walls and large openings. Later on in summer there is not so much want of water, and smaller openings will do; at the same time the bark begins to press on the wood, so that the cell walls must be capable of resisting this pressure; therefore, in summer the pipes have thick walls and small openings. In winter growth stops, and it begins again next spring with the pipes with large openings. These being formed next to the thick-walled ones give the appearance of a ring on a cross section.

These rings are well defined and easily seen in the timber of conifers. In that of broad-leaved trees, though the general manner of formation of the rings is the same, there are slight differences in detail which result in the rings being rather less sharply marked.

Usually one ring is formed each year, so that the age of the tree is known by counting the rings on a section cut at the bottom of a stem. Under certain circumstances, however, such as when the leaves are destroyed by caterpillars in early summer, followed by a second flush, two rings may be formed in a year.

Flowering plants are divided into three great classes: dicotyledons, which have two seed leaves; monocotyledons, which have one seed leaf; and gymnosperms, which differ in many important respects from the other two, though for timber purposes they may be compared with dicotyledons inasmuch as their wood is also characterized by annual rings. The structure of the stem of a monocotyledon 
is entirely different, but need not be noticed here, as no monocotyledon is of importance in British forestry.

Running across the annual rings, on a section of oak, from the centre of the tree to the bark, are seen some thin lines. These are the medullary rays which cause the silver grain when cut in a certain direction. They vary in breadth in the different species, being difficult to see in coniferous timber. Seasoning cracks usually follow these rays.

The rays consist chiefly of soft cells, which keep up a connexion through the harder timber from the pith (the central part of the tree) to the bark, and they are used by the tree, in addition to other parts, as store-houses for any excess of starch, and are possibly concerned in the series of changes whereby sap-wood is ultimately converted into heartwood.

Reproduction. There is a natural provision for a future generation by the means of seeds. All species have male and female organs, though not necessarily on the same tree, the seeds being produced by the females after fertilization by the males. These reproductive organs are called flowers, whether conspicuous or not. To understand the structure of a flower it is as well to examine a simple one like that of a buttercup. On the under-side of a buttercup we find five greenish-yellow floral leaves; these are the sepals, whose duty it is to protect the inner parts of the flower while in the bud stage. The five sepals together are called the calyx. Inside these we find five bright yellow petals, and, if one is examined carefully, a small honey gland or nectary will be found at the base of the upper surface. These petals, which are together called the corolla, serve to attract insects. Within these petals we find a large number of stalked stamens, each of which has a yellow swollen head. This head, which is called the anther, contains a very large number of yellow grains called pollen grains, each of which contains the male fertilizing substance. The stamens are therefore sometimes called the 
male organs of the plant. In the very centre of the flower we find a large number of small bottle-shaped carpels, which together form the pistil. As the carpels of the buttercup are very small it is best to examine a young pea-pod which is a single carpel of the pea-plant in a rather later stage ; it will be seen that the carpel is a hollow body containing ovules which after fertilization grow and become seeds. The carpel is therefore, on the analogy of the stamen, the female organ. The hollow part of the carpel is called the ovary. At the outer end of the carpel we find a thin projection with its end feathery. This feathery portion is called the stigma, and the stalk-like projection from the ovary is called the style. The carpel thus consists of the ovary which bears ovules; the stigma which is feathery or sticky and which catches and holds the pollen grains; and the style which holds the stigma in position, connects the ovary with it, and provides for the passage of pollen tubes to the ovules. In some plants several carpels are joined together to form a single ovary; in this case there are often as many separate stigmas as there are carpels in the united ovary.

The pollen from a ripe stamen is carried by insects from flower to flower and in course of time it touches a ripe stigma, to which it sticks. The pollen grain then throws out a tube which grows down the style into the ovary and finally reaches an ovule into which the contents of the pollen tube are emptied. Fertilization is thus completed and the ovule now grows into a seed and the ovary into a fruit.

The flowers of trees vary in many details from that of a buttercup, but the general process of fertilization is similar. In some cases the pollen is blown about by the wind, and is not carried by an insect. In this case the flower often has no petals, and is frequently inconspicuous. Some trees (e.g. lime) have both stamens and pistils in one flower. Others (e.g. hazel and oak) have them in different flowers on the same tree; in the hazel the familiar catkins are a collection of male flowers 
containing stamens only; the females are small, bud-like, and inconspicuous till fertilization takes place, when they grow into nuts. Species which have separate male and female flowers on the same tree are called monoecious species. In willows, poplars, and juniper, the male and female flowers are on different trees, some trees having male flowers only and others having females only; these species are said to be dioecious.

The seeds of many trees are aided in their dispersal by means of wings (e.g. Scotch pine and other conifers), or by hairs (e.g. poplars and willows). In sycamore, Norway maple, ash, elm, and birch, the fruit is winged. Seeds aided in this way are able to travel further than those with no such provision, with the result that we find young plants of such species coming up at a great distance from the mother tree, whereas young oaks or other plants whose seeds are heavy will not be found naturally reproduced at any distance from the mature tree, unless carried and dropped by squirrels or birds. The seeds of alder and willows are often conveyed by running water.

Besides reproduction by seeds, most of the broad-leaved trees are able to spring up again by means of stool shoots after the tree has been cut down, or by suckers from the roots. This power varies in the different species, and on it depends the production of coppice woods. Some conifers, especially Sequoia sempervirens, have the power of sending up coppice shoots, but the power is so weak with most conifers that it may be neglected for all practical purposes.

The terms 'broad-leaved tree' and 'conifer' or 'coniferous tree' will often be used to distinguish between two classes of our forest trees. For our purposes a broad-leaved tree may be defined as a species whose leaves are more or less broad and flat, and whose foliage is usually deciduous, the leaves falling off in autumn, leaving the tree leafless in winter. Quercus Ilex affords a good example of an evergreen broad- 


\section{THE LIFE HISTORY OF A TREE}

leaved tree, and several broad-leaved shrubs such as holly and privet are also evergreen. A conifer may be defined as a species whose leaves are needle-shaped, or a good deal longer than they are broad, and which, with the exception of yew, juniper, and a few other species, bear cones. British grown conifers are all evergreen, with the exception of larch and Taxodium distichum, the swamp cypress. 


\section{CHAPTER II}

\section{TREE GROWTH IN RELATION TO CLIMATE AND SOIL}

IT is very important to decide correctly what species should be planted on any given spot, as if a wrong one is chosen, no matter how carefully the wood is afterwards treated, the final result will be disappointing. Most species will do fairly well while young on soils and situations where they will never grow into large timber, and it is often only after twenty or thirty years that they become unhealthy and fall off in growth, There is then nothing to do but to fell the wood long before the trees reach a paying size and to start again with another species. If only poles are required the choice is not so difficult, but when large timber is wanted it is essential to choose those species which will be satisfied with the local conditions of climate and soil. The various requirements of the different species are discussed in this chapter, and by a careful attention to all the points referred to, a woodman should be able to decide what is best to plant.

The species to be considered are those ordinarily grown as forest trees in the United Kingdom. The more recently introduced exotic species should usually only be planted on an experimental scale, as it would be risky to plant up large areas with species about which doubt exists as to whether they will succeed in our climate, and whose timber may not be acceptable to timber merchants. The following list includes the chief species to be considered, though some others are mentioned here and there. 
Natural order.

Aceraceae

Oleaceae

Ulmaceae

Betulaceae

Cupuliferae

,

9

,9

Salicaceae

,

,9

,

,9

Papilionaceae

Coniferae

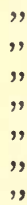

,

,9

,9

,

,9

9

,
Name.

Norway maple

Sycamore

Ash

Common elm

Wych-elm

Birch

Common alder

English or pedunculate oak

Sessile or Durmast oak

Beech

Hornbeam

Sweet or Spanish chestnut

White or Huntingdon willow

Crack willow

Osier

Aspen

Black poplar

Black Italian poplar

False acacia or locust

Norway or common spruce

Larch

Silver fir

Douglas fir

Scotch pine

Austrian pine

Corsican pine

Weymouth pine
Scientific name.

Acer platanoides

Acer pseudo-platanus

Fraxinus excelsior

Ulmus campestris

Ulmus montana

Betula alba

Alnus glutinosa

Quercus pedunculata

Quercus sessiliflora

Fagus sylvatica

Carpinus Betulus

Castanea vesca

Salix alba

Salix fragilis

Salix viminalis

Populus tremula

Populus nigra

Populus canadensis

Robinia Pseudacacia

Picea excelsa

Larix europaea

Abies pectinata

Pseudotsuga Douglasii.

Pinus sylvestris

Pinus austriaca

Pinus Laricio

Pinus Strobus

Notes on a few other species will be found in Chapters $\mathrm{XI}$ and XII.

In determining which of these species should be grown in any given spot the following points require consideration :-

I. The objects of the owner.

2. The species which have done well on the spot or near by.

3. The latitude, elevation above the sea, and aspect.

4. The danger of, or freedom from, frost.

5. The exposure to winds.

6. The light available.

7. The soil.

I. The objects of the ozener. In many cases the wood will be grown with a special object in view, and this will often narrow the choice considerably if the soil and climate suit the 
species desired. If the wood is near a factory requiring a particular species it would probably pay to grow it ; for instance, near a chair factory beech may be desirable; near a woodpulp factory for the manufacture of paper, spruce, poplar, or some other quick growing soft wooded tree would probably be chosen, as the market for the future timber is assured. Near mines, where pit props have a ready sale, larch, Douglas fir, Scotch pine, Corsican pine, or spruce, would be the best species to plant. If there is no such special object in view the woodman's aim should be to grow the greatest volume of the best quality of the most valuable timber. At present, the most paying trees to plant are probably larch, ash, Douglas fir, Scotch or Corsican pines, oak, elm, and black poplar.

2. Species which have done well on the spot or near by. In deciding what species are likely to do well the examination of neighbouring woods is of the first importance. If a species has already succeeded near by, it may be accepted as fairly certain that the various factors of soil and situation suit that species, and that it will be safe to grow it. But in judging from existing woods it is important to remember that mature woods alone are a sufficient guide. A flourishing young wood will only show that the soil and climate suit that species up to its present age or a little beyond, and does not prove that it will continue to flourish up to maturity; a flourishing mature wood, however, may be accepted as proof positive that a new crop of the same species will succeed if properly managed. If, however, the existing woods are in poor condition it must not be at once concluded that the species is unsuitable. The past management must be taken into consideration, as the poor growth may be due to bad treatment and not to unsuitability of soil or climate. As an example the Forest of Dean may be mentioned. Over large areas the present crop of oak is poor, the trees are short in bole and much branched, and at first sight it might be assumed that the soil and climate are not suitable for oak. Nevertheless, 
this is not so; the previous crop consisted of fine tall oak, which produced much-prized timber. The poor condition of the present crop is due to different treatment, the woods having been thinned heavily in order to produce knees and crooks for the use of the Navy, in the days when the ships were built of oak. This sort of timber is now valueless.

3. Latitude, elevation, and aspect. These three factors of the situation must be considered together, as upon them depends the temperature of the local climate. Some trees require warm situations, whilst others will flourish in cold, breezy places; and in deciding what species to plant these three factors are perhaps more important than any others. However good the soil may be, no species will grow to timber size if the climate is unsuited to it, while if the climate is good a somewhat poor soil will often grow good timber.

By latitude is meant the geographical position of the area to be planted. Generally, we may say that the nearer one is to the south of England, the warmer is the climate, while as one proceeds towards the north of Scotland it gradually becomes colder. As, however, the local climate, due to its latitude, is modified very considerably by its elevation and aspect, no general rule can be laid down regarding the species to plant in any county, but roughly we may say that oak, chestnut, common elm, ash, beech, sycamore, Weymouth pine, Austrian pine, Corsican pine, and silver fir succeed best in the south of England; while larch, spruce, Scotch pine, wychelm and birch are more suited to the climate of Scotland. At the same time there are many situations in Scotland where the former trees will do well, and many in England where the latter succeed.

Regarding elevation, the higher up a mountain we go the colder it gets, so that we should only plant hardy species on high elevations. Below $\mathrm{I}, 000$ feet above sea level all our forest trees will do well if not too much exposed to high winds, if the other factors of the climate and the soil are suitable. It is 
only when we wish to plant land above I,000 feet that we must take elevation into consideration. It is generally considered that forests will not pay above $I, 000$ feet, but if properly treated, and grown densely, it is likely that several species would produce paying timber at a greater elevation (provided that they are near a possible market), especially in the ravines and glens where they are sheltered by higher land.

When planting above $\mathrm{I}, 000$ feet it is best to use only Scotch pine, Austrian pine, larch, spruce, sycamore, and birch, which are more likely to succeed than other species.

Turning now to aspect, south and west aspects are warm, and they are exposed to strong winds and heavy rain, but as the sun shines strongly on them the soil dries rapidly. North and east aspects are cool and the winds are less strong but are drier and colder than those from south or west; the soil remains moist for a good time after rain; vegetation is later in awakening in spring, and owing to this plants escape to a great extent from severe damage by late frosts. Moreover, thaws are more rapid on warm aspects than on north and east ones, and rapid thaws do more harm to plants than slow ones.

It is obvious that these differences in the climate of the various aspects must have their effect on the growth of trees, and we find in practice that, other conditions being equal, some species do better on certain aspects than on others.

The aspect most suited to a species may vary in different parts of the country, because much depends on the latitude and elevation. Thus a tree which does best on a north aspect in the south of England will possibly prefer a south aspect in the north of Scotland, and one which does well on a north aspect at a low elevation may do best on a south aspect at a high elevation.

As a general rule the following aspects are best for the various species, more especially in the Midlands and south of England :- 
North and east aspects are the best for ash, beech, larch, Douglas fir, hornbeam, silver fir, and spruce.

South and west aspects are best for oak, chestnut, elm, maple, sycamore, false acacia, Austrian pine, and Corsican pine.

The following species will do well on any aspect: Alder, aspen, birch, hazel, willows, Scotch pine, and Weymouth pine.

When the land to be planted varies in its aspect it will be well as far as possible to plant each species on the aspect which suits it best, provided that the soil is suitable. This is especially important with the larch, which is apt to get much diseased; it should only be grown on cold north and east aspects, where its bursting into bud will be rather delayed, and where the climate more nearly approaches that of its natural home in the Alps.

4. The danger of, or freedom from, frosts. Frosts which occur in winter seldom do great damage to our indigenous trees, though they may kill exotic plants. Early frosts, or those occurring in early autumn, do a certain amount of harm by killing the young unripened shoots, but they seldom kill young trees outright. It is the late spring frost which does the greatest damage and which must be guarded against. Frosts occurring in May are especially dangerous, while those coming in April are bad but do not do so much harm, as vegetation is not so far advanced.

The effects of frost may be recognized by the frozen plants, or parts of plants, becoming soft and flexible; they usually turn brown, hang downwards, and wilt.

Species which burst into leaf late in spring do not suffer so much as those which do so earlier, as there is then less chance of a bad frost; at the same time the young plants of almost all species will suffer considerably if a frost occurs just as the buds are bursting.

The date when a species bursts into leaf depends on the elevation and aspect, and it is therefore impossible to say that a species is hardy or tender in every circumstance. On a 
north aspect at a high elevation a species may break out into leaf so much later than under opposite conditions that it may escape from a frost which does great damage to the same species growing on a south aspect at a lower elevation.

Taking all things into consideration we may group the species as follows:-

Very frost-tender: Ash, false acacia, sweet chestnut, beech, silver fir.

Moderately hardy: Oak, Douglas fir, maple, sycamore, spruce, alder.

Hardy: Lime, elm, aspen, willows, birch, hornbeam, larch, Corsican pine, Austrian pine, Weymouth pine, Scotch pine.

Of the two varieties of the Douglas fir, the green or Pacific variety appears to suffer most from early frost, and the Colorado or blue variety from late frosts.

This list may be taken as fairly accurate in most cases, and a little careful observation will easily enable a woodman to modify it according to the local conditions of his own woods.

Of other species, black walnut, hickories, Turkey oak, and Jeffrey's pine are all frost-tender; while American ash, Sitka spruce, Japanese larch, white spruce, Lawson's cypress, Wellingtonia, Nordmann's fir, and red cedar are hardy.

Danger is greatest while the plants are young. A single night of frost while seeds are sprouting may kill a whole bed of seedlings, and danger continues during the first four or five years of life, and is then gradually reduced as the plants grow taller; it is not at an end till they have grown above the local frost zone, the height of which varies according to the shape of the ground. In damp, deep, narrow valleys forming what are called 'frost holes', quite tall trees may have their foliage destroyed by a bad frost. Woods on hill sides and high land suffer least. Frosts are worse on north-east, east, south-east, and south aspects, than on north or west ones, and are worse on wet clayey soils than on lighter ones. 
In all places where frosts are known to be bad, care should be taken to plant frost-hardy species, of which perhaps the pines, spruce, and hornbeam are the best, the latter especially being able to resist severe frosts. Larch, though hardy, is very liable to suffer from diseases in such places, and should not be planted except as a temporary shelter for other trees. The choice of species is greatly enlarged if there is an existing wood on the spot, as the new crop can be planted under the shelter of the old wood, which will considerably reduce the danger. In this case the effect of the shade thrown by the older crop must be carefully considered, as pointed out a few pages further on, and the overhead cover must be reduced to the degree which will suit the species to be planted. It is not only directly under the shade of the older trees that the frost is reduced; in fact, a very thin overwood of scattered trees will very materially reduce the damage done to young trees planted under and between them.

If no older crop exists, and it is desired to plant a tender species, it will be necessary to start operations by planting a thin wood of birch or larch, and to introduce the new crop when these are tall enough to give some shelter. The birch or larch should be cut out when the young crop is well established and out of danger.

Put shortly, the following measures may be taken to protect plants from frost :-

(a) In a forest mursery.

I. Form nurseries on north and north-west aspects.

2. Do not sow seed before the first of May, and cover it well.

3. Cover the seed beds with dead leaves in autumn, or with branches of trees in spring, or place mats over the seed beds, on short supports, when a bad frost is expected.

(b) In the forest.

I. Drain wet places before planting.

2. Plant tender species under a light shelter wood. 
3. Use large plants two to three feet high.

4. When about to plant in a frosty place lift the plants from the nursery early and heel them in, as this delays their sprouting.

5. Exposure to winds. In places exposed to cold or dry winds it is necessary to plant a shelter belt of evergreen trees which will protect the young woods behind them. This should be completed some years in advance of the main crop and should be 40 to 50 feet wide, the trees being planted rather far apart on the outside edge, so as to encourage them to branch right down to the ground. The outer rows may be planted at least 6 feet apart, and should be kept in an open condition, the inner rows being 4 feet apart. Spruce, Austrian pine, Cembran pine, and Cupressus macrocarpa, make good belts, and one of these species may be chosen according to the soil. Spruce, although a shallow rooted tree, is fairly wind-firm if grown from the commencement in a thoroughly open position, as it throws out long roots to a considerable distance, and gets a good hold on the ground.

Where the woods are exposed to strong westerly or southwesterly gales a belt of existing weather-beaten trees should be left standing, or, if no wood already exists, a shelter belt should be formed consisting chiefly of broad-leaved trees, as these are less liable to be blown down than conifers. Both sycamore and beech are good for this purpose, and conifers may be mixed with them in the back rows to thicken the belt.

Along the sea coast, where the winds carry salt spray, sycamore, Norway maple, beech, white poplar, birch, cluster pine, and Austrian pine are the best species, and a broad belt of these will, when once formed, efficiently protect young woods planted behind their shelter.

6. The light available. In order that the chlorophyll in the leaves may be able to make food material, it is essential that they should have sunlight, and it is a matter of first importance 
for a woodman to thoroughly understand the effect of light and shade on the growth of the different species. A tree which does not receive enough light languishes and eventually dies. Moreover, any individual branch which is too much shaded will die. This fact is taken advantage of by the woodman to make his trees grow into the desired form. If, for instance, an oak wood is planted closely, say at 2 feet apart, after a few years it will enter into the thicket stage, and become densely crowded. In this state a struggle for existence is set up in which each tree is striving to outgrow its neighbour in order to obtain light. This causes the trees to grow rapidly in height, while at the same time the branches are killed off by the heavy shade of the surrounding trees, and we thus get trees which are tall and clear of branches. If, on the other hand, we plant the oaks far apart there is no struggle for existence, as each tree has plenty of light, and it develops a large crown and large side branches.

The woodman, as explained in Chapter VI, regulates the amount of light given to any tree by making thinnings, and causes that tree to grow into the shape desired.

The actual amount of light which must be given to a tree depends on the species. Some must have their heads fully out to the light, and will not stand any overhead shade at all. Such species are called light-demanders. Others will bear a considerable amount of shade and are called shade-bearers. Others occupy an intermediate position, demanding light on poor soils and situations, but bearing a fair amount of shade under favourable conditions. These trees may be termed moderate shade-bearers.

The following list shows the species in the order in which they demand light :-

Light-demanders.

I. Larch, birch.

2. Scotch pine, poplars, willows, false acacia, Corsican pine.

3. Oak, ash, sweet chestnut, mountain pine. 
4. Elm, alder, Austrian pine.

Moderate shade-bearers.

5. Lime, Weymouth pine, Norway maple, sycamore, hazel, Douglas fir, spruce.

Shade-bearers.

6. Hornbeam.

7. Silver fir.

8. Beech.

In a general way it may be said that the light-demanders will bear no shade at all, and must be planted fully in the open, except that when coppiced the broad-leaved lightdemanders will usually bear a light shade thrown by an overwood of seedling light-demanders. The shade-bearers may usually be planted under a cover of light-demanders, which only shade the ground slightly, especially if the leaf-canopy is at some height above the ground.

The actual amount of shade which any species will stand must be learnt by experience-not a difficult matter if the woodman keeps his eyes open while walking through the woods. When planting under the cover of existing woods the foregoing list must be borne in mind. Under a cover at all dense silver fir, beech, or hornbeam must be chosen. In the openings where there is no direct overhead cover but some side shade, spruce, Douglas fir, Weymouth pine, and sycamore will probably succeed.

It must be understood that all the shade-bearers will grow much faster in the light, but they will remain alive and grow, more or less slowly, under cover, and when at any future time they obtain more light they will then shoot up and fill up any blanks in the leaf-canopy.

In early youth beech and silver fir might be termed shadedemanding, as they must have shelter, being frost-tender species. Ash and sycamore seedlings will also bear heavy shade for the first four or five years.

This question of light and shade has not been properly 
understood by British woodmen, and in a large number of cases unsuitable species have been planted under the shade of standing trees, with the result that the plantation has failed.

When considering whether any particular species, not mentioned in this list, is light-demanding or shade-bearing, a useful broad rule is that a tree with a light thin crown is usually a light-demander, while one with a dense crown is a shade-bearer.

7. The soil. The character of the soil is not so important as that of the climate, nevertheless trees make certain demands upon the soil which it must be capable of fulfilling; thus it must give space for the roots to grow so that the tree may obtain a good hold upon the ground, and it must give moisture and nourishing substances in sufficient quantities.

For practical purposes soils may be divided into clays which contain over 60 per cent. of pure clay; sands which contain over 75 per cent. of pure sand; loams formed of clay and sand in fairly equal quantities; limy or calcareous soils containing over Io per cent. of carbonate of lime; and peats which consist chiefly of vegetable matter with very little mineral earth. These soils merge one into another and thus we get such soils as loamy sands, sandy loams, loamy clays, loamy limes, \&c. Marls are limy soils with over 30 per cent. of clay, the lime being equally admixed throughout each particle of soil.

With regard to the mineral composition of a soil, the minerals most necessary for the growth of forest trees are potash, lime, magnesia, iron, sulphur, and phosphorus, and fortunately almost every soil contains these minerals in sufficient quantity to support tree growth, though possibly there may not be enough water to hold them in solution, in which condition alone can they be absorbed by the roots. A crop of trees, provided the humus or layer of leaf-mould formed by the decaying leaves is not removed, requires a far smaller quantity 
of minerals than a field crop. The fact that agricultural crops are annually removed totally, except in some cases the roots, means the relatively rapid exhaustion of the mineral matters in the soil. This does not apply in the case of a wood, where each year a considerable quantity is returned to the soil in the fallen leaves and only a very small proportion is retained in the timber, to be finally removed when the timber is felled. As a consequence a soil can support a continuous succession of forest crops without any necessity for manuring, and, as another consequence, we find that soils which are too poor for agricultural crops can, as a rule, be profitably employed for afforestation. Conifers require smaller quantities of mineral matters than broad-leaved trees, and should therefore be preferred for planting up minerally poor soils.

Turning now from the mineral character to the physical properties of the soil we find these are of far greater importance, and that a soil which has a sufficient depth, a suitable degree of porosity, and a proper amount of moisture, may be accepted as a good forest soil whatever the mineral composition.

With regard to depth we may say that four feet of soil, including the subsoil so far as it is well broken up, is sufficient for the good growth of all our forest trees. A deep soil is always more favourable than a shallow one, as in it the roots can obtain a good hold, and have a larger space in which to search out and obtain supplies of water and mineral matters. Moreover, a deep soil is less likely to become dry in dry weather or to become swampy after a heavy rainfall. A deep soil has a great effect upon the height growth of trees, so much so that a fair estimate of the depth of the soil may be made by looking upwards to see the height of the trees.

The different species are content with varying depths of soil according to the nature of their root system; the spruce, for instance, having roots which spread out laterally and remain close to the surface, will grow to a good size on 
shallow soil; while the oak, which has a deep burrowing root system, will not grow to fine proportions except on a deep soil.

The chief species may be arranged as follows with regard to the depth of soil they require. The depths given are necessary for the species to grow to large size, but they will produce good saleable poles of medium size on shallower soils.

Species which will growe on shallowe soils, about one foot to eighteen inches in depth: Spruce, mountain pine, birch, aspen, mountain ash.

Species which require moderate depth, from eighteen inches to two feet: Austrian pine, Corsican pine, Weymouth pine, beech, hornbeam, black poplar, willows, alder, horse-chestnut.

Species which require greater depth, from two to three feet: Scotch pine, elms, Norway maple, sycamore, white poplar, Douglas fir.

Species which require the greatest depth, over three feet: Silver fir, larch, ash, lime, sweet chestnut, and oaks.

Regarding the degree of porosity of a soil neither a very loose soil nor a very heavy one is favourable. In a loose soil the roots cannot obtain a good hold on the ground, and the trees are apt to be blown down; such soils do not retain moisture, and soon dry up. In a very heavy soil the roots cannot penetrate easily, air cannot get in, nor can water percolate, and the surface is apt to be swampy. The best soils are those of middling consistency, such as a good loam, or a limy soil with a good layer of humus. On such a soil most species will do well, while, as a rule, we should plant broad-leaved trees on soils which are decidedly heavy, and pines on very light soils.

The moisture contained in a soil is of first importance. If the ground is very wet and swampy air cannot get in and the roots decay, while if the soil is very dry the trees get insufficient moisture and there is not enough water to dissolve the mineral matters. The most favourable soil is one which 
is fresh all the year round, but more especially in the growing season. Such a soil will suit almost all species. The different species can be classified as follows with regard to the moisture they demand:-

Species which demand a wet soil. (In summer water runs off in drops from such a soil on the application of a little pressure) : Common alder, ash, most poplars, and willows.

Species which like a moist soil. (In summer such a soil does not become dry for more than one inch below the surface) : Hornbeam, elm, lime, mountain ash, pedunculate oak.

Species which like a fresh soil. (In summer such a soil does not become dry for more than six inches below the surface) : Silver fir, spruce, larch, beech, sessile oak, Norway maple, sycamore, Weymouth pine, sweet chestnut, Douglas fir. (Spruce will succeed sufficiently well on a wet soil.)

Species which will do well on a dry soil. (Such a soil becomes dry to a depth of twelve inches within a week after heavy rain): Corsican pine, Austrian pine, Scotch pine, birch, false acacia, aspen.

Stagnant water is unfavourable to all species.

A woodman can do much to regulate the amount of water in a soil by draining those which are too wet, and by keeping a good cover of trees over those which are too dry.

Taking all the different factors of the soil into consideration it is best to choose oak, beech, hornbeam, chestnut, or spruce for stiff clay soils; Scotch pine, Corsican pine, Austrian pine, Weymouth pine, false acacia, or birch, for $d r y$ sandy soils; while, if the soil is sandy, but moist, sycamore, chestnut, and spruce may be added to this list, and on almost pure sands on the sea coast in the south of England the cluster pine will succeed. Beech is decidedly the best species for chalky or limy soils, and with it may be mixed oak, sycamore, ash, elms, and larch to increase the revenue; if such a soil is too dry and shallow for beech, then Corsican and Austrian pines are the best species to grow; Douglas fir and chestnut should not 
be attempted on limy soils, as it is said that they do not grow to large size on such soils. On peats ash, alder, birch, beech, white poplar, willows, wych-elm, larch, spruce, Austrian pine, and Scotch pine will do well if the peat is first drained and if a little mineral soil is mixed into each hole at the time of planting. On loams and sandy loams most species will succeed and grow to a large size, and naturally the most valuable will be chosen.

Species which will accommodate themselves to various soils and which will do fairly well on poor soils are called accommodating trees; such are Austrian pine, Corsican pine, Scotch pine, Weymouth pine, birch, poplars, most willows, false acacia, mountain pine, and white alder.

Species which must have a good soil to produce large size timber are called exacting trees; such are silver fir, beech, chestnut, oak, sycamore, ash, and elm. Intermediate between the two classes are certain species which do not require the best class of soil, and yet which will not grow in the poorest soils. These may be called moderately exacting trees; this class includes spruce, larch, alder, lime, osiers, horse-chestnut, hazel, hornbeam, Norway maple, and Douglas fir. Whenever the soil to be planted does not appear exactly suitable to any particular species, it will be safest to plant one or more of the accommodating trees, as the risk of failure is then reduced to a minimum.

It must always be the first aim of a woodman to improve the physical properties of the soil and to maintain its fertility. Fortunately there is a simple way of doing this by encouraging a heavy fall of leaves to form humus, and by preserving this when formed. By keeping a dense cover overhead, a heavy fall of leaves will be obtained which will slowly decompose into an excellent leaf mould; on the other hand, if sun and air are let into the woods by overthinning the humus will decompose rapidly, and will disappear, with the result that the soil will gradually deteriorate. Humus improves the soil in 
many ways. It acts as a manure, returning to the soil much of the mineral matter taken out of it, and, in addition, provides a large amount of vegetable matter which on decomposing forms carbon dioxide gas, ammonia, and humic acid, and thus the fertility of the soil is improved. The acid is dissolved in rain-water, and acts on the minerals in the soil, making them soluble and therefore useful to the trees. Humus also acts like a sponge, retaining moisture, which gradually finds its way into the soil and is available for the roots of the trees. It also improves the degree of porosity, making a stiff soil looser and a loose soil heavier. It adds in the course of years a good deal to the depth. Finally it acts like a blanket and keeps the soil warmer in cold weather and cooler in hot weather than a bare soil.

The humus of all species, however, is not equally good. During youth, while in the thicket stage, all species form a good humus and improve the soil, but when the woods begin to open out, between the twentieth and thirtieth years, certain species have only a light cover and their leaves do not form sufficient humus. As a general rule shade-bearing species are soil improvers, while under a cover of light-demanding trees the soil gradually deteriorates, owing to the fact that the cover is broken and sun and air get into the ground and the humus disappears.

Beech is the greatest soil improver, because it has a dense cover and throws a heavy crop of leaves which decay slowly and form the best kind of humus. Hornbeam, silver fir, spruce, and Douglas fir are also good soil improvers; chestnut, sycamore, maple, and hazel are moderately good; while oak, ash, larch, birch, poplars, willows, and elm are all species under which, when grown pure, the soil will gradually deteriorate. Of the pines, Weymouth pine gives the best humus, whilst Scotch, Austrian, and Corsican pines improve the soil for some thirty or forty years; after that age they usually open out, and the soil begins to deteriorate. 
It is owing to the great soil improving qualities of the beech that the woodman will be often recommended to grow this tree together with the more valuable species. Although in many places beech timber is not of very great value, yet a place should be found for it in every wood, as other and more valuable species will grow better in mixture with beech than without it, as they get the advantage of the humus and improved soil, while, in addition, they grow cleaner timber owing to the heavy cover of the beech, which kills off the branches. This is easily observed in any oak and beech wood; where the oak has been grown densely surrounded with beech it will almost always be found to be taller, cleaner, and of better shape than when it has been grown pure; if a wood of pure oak has reached the age of about a hundred years the soil will almost always be found to have deteriorated under it, while humus is conspicuous by its absence; the oaks will also almost certainly be very branched.

A good rough method of determining the quality of the soil is to dig holes here and there throughout the area to a depth of four feet if rock is not found at a less depth. One side should be made vertical, and on this the thickness of humus and of the different layers can be measured. To determine the degree of porosity place a little soil in a test tube with three times its bulk of water. Shake well and allow it to settle. The rough grains of sand and gravel fall to the bottom, and then the fine grains of sand ; the clay comes down in a fine state of division and forms a layer above the sand, while humus or vegetable matter floats on the surface. From the proportion of sand and clay the degree of porosity can be determined sufficiently accurately for all practical purposes, the more sand there is the more porous being the soil. To decide whether much lime is present pour a few drops of dilute hydrochloric acid on to a little soil ; if there is a distinct effervescence lime is present. 


\section{CHAPTER III}

\section{PURE AND MIXED WOODS}

WHEN species suitable for the soil and situation have been chosen it is necessary to decide whether the plantation shall be pure or mixed. A pure wood is one where a single species is grown, while if there are two or more species the wood is a mixed one.

Opinions differ to a certain extent as to whether pure or mixed woods are the best, but, as a general rule, over a large area it is best to have mixed woods, for the following reasons :-

I. Over a large area the soil and climate probably vary, and if the whole is planted up with one species the growth will be unequal. If, on the other hand, a mixed wood is planted, each spot can be stocked with the species which appears likely to do best, and therefore every part of the forest will be utilized to the utmost extent, and the financial returns are likely to be better than if the whole area contained one species only.

2. Better timber of the valuable light-demanders like ash, larch, and oak can be produced if these species are grown mixed with shade-bearing trees, like beech, than if grown pure, because they obtain the benefits of the humus thrown by the shade-bearer, and because their branches are naturally pruned.

Moreover, a larger outturn per acre is usually obtained from such a mixture, as the light which filters through the crowns of the light-demanders is utilized by the shadebearers.

3. If a light-demander is grown pure, the soil will, after 
a time, deteriorate. This must be prevented by growing the light-demanders mixed with shade-bearing soil-improving trees. In certain circumstances it is, however, legitimate to plant the light-demanders pure, afterwards underplanting with a shade-bearer. Such a wood is a mixed one for the greater part of its life.

4. By mixing different species together the damage done by wind, fire, frost, insects, and fungi is usually reduced. Thus, by mixing a deep-rooted species like Douglas fir with a shallow-rooted one like spruce the danger from storms is minimised; an additional advantage of such a mixture is that each species draws its nourishment from different layers of the soil, which is, therefore, utilized to the fullest extent. Conifers are less exposed to danger from fire when mixed with broad-leaved trees. Frost-tender species like beech escape damage by frost when planted under, or between, hardy, light-foliaged species like oak or birch. Insects are less dangerous in mixed woods as they usually attack only one species, and the isolation of the stems and crowns by other species retards the progress of the insect pest. Fungi, like the larch disease, do less damage as the spores cannot spread so easily, each tree being more or less isolated from other trees of the same species.

5. Mistakes made in the selection of species can be more easily put right, as unsuitable species can be removed in the thinnings without leaving the ground bare.

6. The demands of the market may be better met from mixed than from pure woods. If there is only one species in a wood and the demand for that species, for some reason, is reduced, there is nothing to sell except at a sacrifice. Too much stress, however, should not be laid on this, as if one has a large quantity of well-grown timber of any species one can usually obtain a good price for it.

7. Mixed woods are usually more beautiful than pure ones, and are also better for sport. 
On the other hand, mixed woods are more difficult to manage than pure woods, and have the serious disadvantages that the various species often mature at different ages, and that the timber, when felled, is not all of one grade. Again, in a mixed wood the less valuable species is occupying land which might be occupied by the more valuable species. In these respects pure woods have the advantage.

On the whole the advantages of mixed woods on a large area outweigh the disadvantages, though on small areas pure woods may often be preferable.

The advantages of a mixed wood will only be realized if the following conditions are attended to :-

I. The soil and climate must be suitable for all the species chosen.

2. The mixture must be such that the fertility of the soil is preserved or improved.

This practically means that the soil-improving species must appear in every wood, and that light-demanders must be mixed with shade-bearers.

3. The mixture must be so arranged that one species does not outgrow and kill the others, thus establishing a pure wood.

In this connexion the rate of growth in height of the various species, more especially in youth, is of great importance. Assuming favourable conditions, the species may be arranged as follows, commencing with the fastest growing species :-

I. Douglas fir (Pacific variety), birch, larch, and Black Italian poplar.

2. Aspen, alder, Norway maple, sycamore, ash, lime, elm.

3. Weymouth pine.

4. Scotch pine, Corsican pine.

5. Austrian pine.

6. Sweet chestnut.

7. Beech, oak.

8. Hornbeam. 
9. Spruce, Douglas fir (Colorado variety).

I0. Silver fir.

Some species like larch, Douglas fir, Weymouth pine, Scotch pine, and birch continue their fast growth until they have completed their principal height growth; others, like hornbeam, remain slow growers through life; but after the first twenty years, spruce, silver fir, beech, and oak increase their rate of growth, and soon catch up and pass ash, Norway maple, and sycamore, which do not then grow so fast.

Trees usually grow in height all through their life, but a time comes when the rate of growth decidedly diminishes, and it is this period at which we say that the principal heightgrowth ceases. This occurs with Scotch pine at about the sixtieth year, with spruce at about the seventieth, and with oak and beech between the eightieth and ninetieth years. The crowns of broad-leaved trees become rounded off at this period.

The rate of height-growth must be well considered when planting a mixture of two or more species, as upon it depends the management of the mixture.

There are three usual forms of mixture: by single trees when each tree is surrounded by another species; by alternate lines where one line consists of one species, and the next line of another; and by groups where each species is planted pure in a small group surrounded by groups of other species.

A mixture by single trees is difficult to manage, and is only possible where all the species grow more or less at the same rate. This is, however, very seldom found to be the case in practice, as usually one species grows faster than the other and the wood tends to become a pure one as the slow growers are overshadowed by the fast growers. Whenever such a mixture has been formed the woodman must very carefully watch the growth of the various species and by the judicious use of the axe must prevent the extinction of one species by another. 
A modification of this system, when one species is planted singly at some distance apart into a plantation of another species, is, however, excellent in certain cases. For instance, where larch is to be grown in places where it is liable to disease, it is an excellent plan to plant it singly here and there at about 20 feet apart into a plantation of another species of which the best is beech. Each larch then grows completely isolated from other larches.

In the same way, ash, oak, elm, sycamore, poplars, and all fast growing, light-demanding, broad-leaved trees may be scattered singly in beech woods to increase the revenue, or in woods of evergreen conifers, care being taken in the thinnings to prevent the beech or evergreen conifer from topping the single tree. It is perfectly useless to plant spruce, Douglas fir, or any evergreen conifer singly into a wood of larch or of a light-demanding, broad-leaved tree, as its branches will not be naturally pruned and its timber will never be of good quality. Such trees may, however, be mixed singly into beech woods, as in this case the side branches will die off.

As the tree to be planted singly will usually be the most valuable species, as many should be planted in the acre as is possible. When it is one, like oak or ash, which is not very liable to disease, it can be put in, say, at I2 feet apart, but with larch 20 feet apart is safest.

Mixtures in alternate lines may be made when the species are of about the same height-growth or when the slow grower will bear the shade thrown by the fast grower. The future management of a wood arranged in this way is comparatively easy and the slow grower does not get easily suppressed as the light shines down the lines between the tops of the taller species; but, on the other hand, if the fast grower forms cover over the slow grower the advantages of isolation are lost. If this is likely to be the case, as it usually is with larch and beeç, it is better to plant, say, three or four lines of the slow 


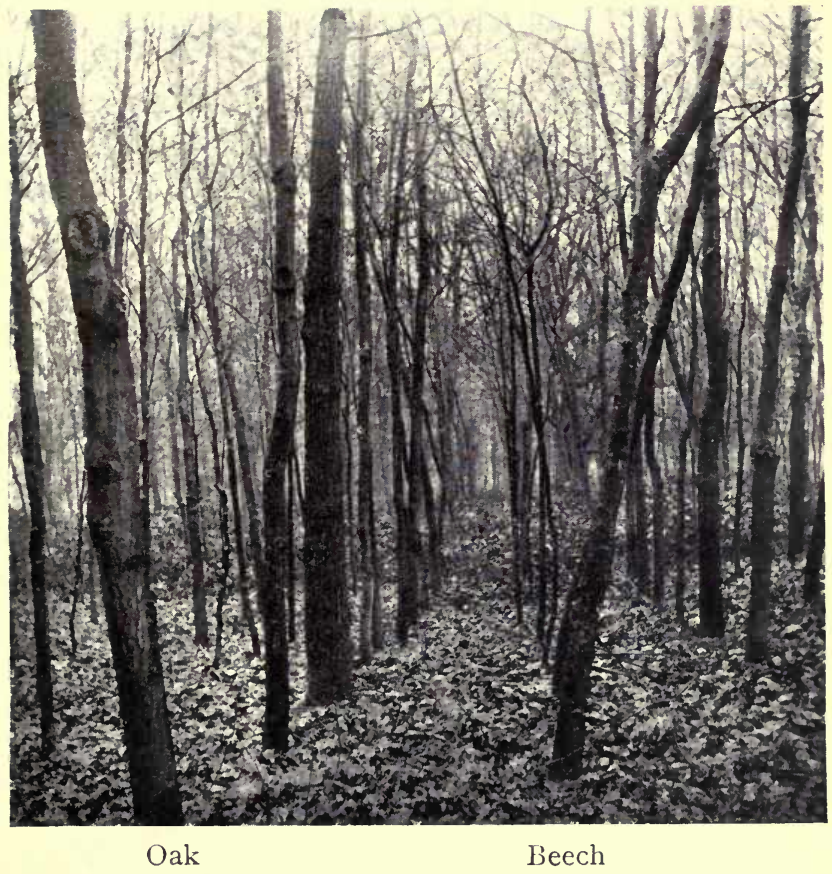

Oak and beech planted $\mathbf{1} 89 \mathrm{I}$ in alternate lines. Oak 28 feet high and up to $20 \frac{1}{2}$ inches girth. Beech have been topped as they outgrew the oak. In the background pure oak with brambles beneath. Coopers Hill. January, 1910. 
40 ont

and and 
grower and then one of the fast grower. As a general rule not more than two species should be intimately mixeò together on any one spot, as otherwise difficulties may arise later on owing to the different rates of height growth.

When the species to be grown vary considerably in heightgrowth it is best to separate them by planting in groups of one species only. The groups may vary in size from a few square yards up to an acre or so according to circumstances. No group consisting of a light-demander should be large enough to become practically a pure wood. The size and shape of the group may depend on the nature of the soil, but no hard and fast rule can be laid down about this. In natural woods the different species are usually found in irregular patches and groups, and it is this arrangement that the woodman should try to imitate, always trying to get as intimate a mixture as he can without risk of one species ousting the other. For instance, where it is decided to plant oak and beech, if it is known that, in the locality to be planted, the oak grows faster than the beech, the two species may be planted in alternate lines, because there will be no fear of the oak being suppressed and the beech will grow very well in the shade thrown by the oaks, and the intimate mixture obtained will be excellent. If, however, the beech is the faster grower, as it often is on certain soils, the two species should be put into separate groups, each group of oak being surrounded with beech. By doing this, only the outer oaks will be suppressed, while those in the centre of each group will grow into fine trees. If the groups of oak are fairly small to start with, the number of trees in each group being gradually reduced in the thinnings, a fairly intimate mixture of oak and beech will finally be obtained.

By planting in groups, any number of species may be grown in a wood, each in a separate group, and the wood as a whole will have the character and advantages of a mixed wood. In the author's opinion, the formation of mixed woods by 
groups is the best method, while to facilitate future sale of the timber, as far as possible the various groups in a block of forest should consist of species which mature at the same time. Thus groups of larch, spruce, Douglas fir, and Scotch pine could be grown in one block, the whole to be felled at say sixty or seventy years of age.

Mixtures may be of three types, according to whether they are mixtures of shade-bearers only, of light-demanders and shade-bearers, or of light-demanders only.

Of mixtures of two shade-bearers only, silver fir and spruce ; silver fir and beech; and spruce and beech are the best, but they are not species which are sufficiently valuable to plant on a large scale alone, though they can be used for filling in gaps in existing woods.

Mixtures of light-demanders with shade-bearers are of more interest to the woodman. These mixtures can be, in certain cases, formed at once by planting in alternate lines when it is certain that the light-demander is the quickest grower. Thus larch and beech (where there are three lines of beech to one of larch), ash and beech, poplars and spruce are all good, while oak and beech can be mixed thus in localities where oak is the faster grower. Neither larch and spruce, nor ash and spruce, are good in this form, nor is oak and spruce, as the spruce takes up so much moisture from the soil that the oak goes 'stagheaded' (or dies at the top). Larch and Douglas fir is a good mixture, but is best formed by groups, as in alternate lines the Douglas fir will probably outgrow the larch and will not get properly clear of branches. The pines can be mixed alternately with beech, spruce or silver fir with good results, provided the shade-bearers are given some help at first by planting three or four lines to one line of the pines.

Where the light-demander is likely to be outgrown, the mixture may be by groups, or, especially with oak, the lightdemander may first be planted pure, the shade-bearer being 


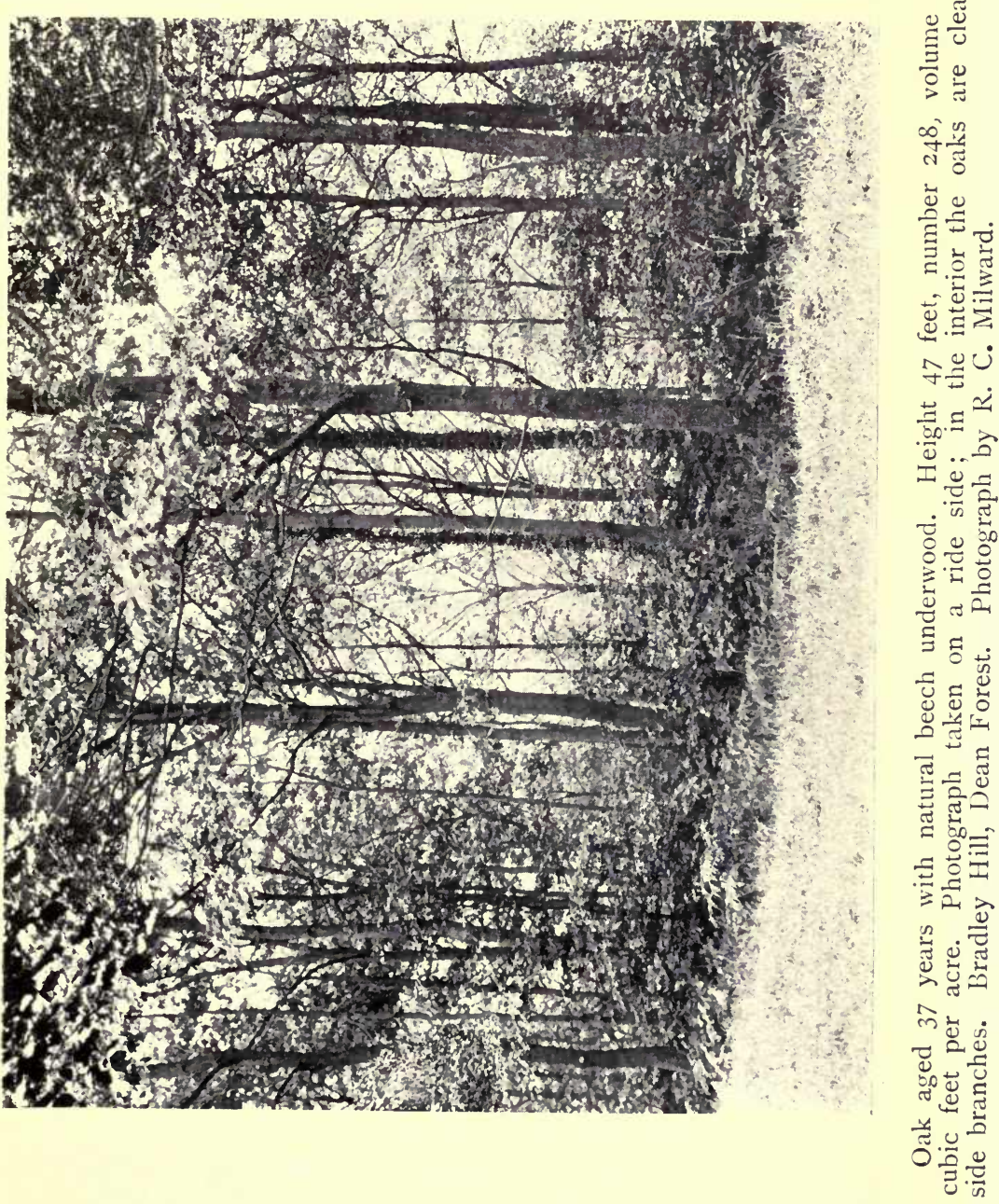




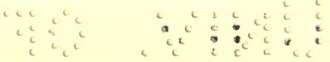

$\therefore$ 
underplanted later on, thus forming an uneven-aged wood. In the majority of cases beech is the best species to use for this under crop, the action of which may be explained as follows:-If a pure wood is planted of some light-demanding species like oak, larch, or ash, after a certain time, depending on the species, the wood begins to open out and forms only a thin canopy which is no longer able to protect the soil. If the wood is then left alone the soil deteriorates, the humus decomposes too rapidly and disappears, and a rank growth of weeds soon covers the soil; moreover, the trees form large crowns, and if this state of affairs is allowed to continue the timber will not be of first-class quality.

Oak woods begin to thin out when between thirty and fifty years of age; and larch between the fifteenth and twenty-fifth years, the actual time being indicated on the ground by the appearance of brambles and other weeds. When this happens a fairly heavy thinning should be made, cutting out all dead and dying trees and very badly shaped ones, so as to allow more light to reach the ground. Then the wood should be underplanted with beech, silver fir, or hornbeam according to circumstances, while Nordmann's fir may also prove suitable for this purpose. Under no circumstances should any lightdemanding species be used for the underwood.

The underwood will grow, slowly it is true, and will in course of time form a thicket under the overwood. From this time on it will throw a heavy fall of leaves to the ground which will form humus, and this will act as a manure to the valuable trees forming the overwood and will cause them to grow rapidly in volume. The soil will be well protected in every way. Individual trees in the underwood, wherever they get enough light, will grow and fill up blanks in the overwood, thus keeping the cover dense and the area fully stocked, and the wood gets the advantages of a mixture. As the trees in the underwood grow upwards they will shade and kill off any small branches formed on the stems of the overwood and will 
thus improve their value-causing them to form clean timber and also to become more cylindrical.

Underplanting should therefore be carried out in all woods of light-demanders, as soon as the latter are no longer capable of protecting the soil by themselves. Care should, however, be taken to see that the existing crop is worth underplanting; for instance, open oak woods are seldom worth underplanting if this has been left till they are sixty or seventy years old, as the oaks are then too old to respond to the improved character of the soil. Put shortly, only valuable species, sound and of good shape, and young enough to respond to the treatment, should be underplanted, as to underplant badly growing woods is a waste of money and it is more profitable to cut them and to replant the area.

It must be remembered that we do not expect to obtain fine timber from the underwood itself. A certain amount of produce will be obtained from it, but we look chiefly to the improved value of the overwood to repay us for the cost of forming the underwood. The fairly heavy thinning made at the time of underplanting will, however, often produce enough to pay the cost of the operation, especially if the wood contains larch which have been grown as nurses and which must be removed for the benefit of the permanent species. One case where underplanting is of special value is that of a larch wood between fifteen and thirty years of age, where the trees are badly attacked by the larch disease. In a wood of this type the best thing to do is to make a heavy thinning, cutting out all, or the larger portion, of the diseased stems, leaving only the tallest and most healthy trees; then the area is filled up with whatever kind of shade-bearing species appears to be most suitable.

In an article which appears in the Board of Agriculture Fournal for March, 1906, it is stated that this system is carried out with success on the Novar Estate in Scotland, the larch being reduced to from $35^{\circ}$ to 600 trees per acre, at about 
fifteen years of age. The most suitable species for underplanting the larch are found to be Picea sitchensis (Sitka spruce), Douglas fir, Tsuga mertensiana, Thuya gigantea, Lawson's cypress, and Abies grandis. Here these plants are put in cheaply as two-year seedlings by dibbling them in; the ground being clear of weeds, it is not necessary to use large plants. The underwood is said to form a thicket covering the ground in from six to ten years, and the rate of growth of the underwood averages about one foot and a half annually when once the plants are established.

In the course of time an underwood thus formed will catch up the overwood and from that time onwards the crowns of the two species are fairly intimately mixed.

It is not usually good to mix light-demanders only, without any shade-bearers, as the soil deteriorates under them, and one species very often outgrows and suppresses the other. Such mixtures as the following are often found in existing woods :-

Oak with ash, elm, or sweet chestnut.

Oak with alder or birch.

Oak with Scotch pine or larch.

Scotch pine with birch.

Scotch pine with larch.

Scotch pine with sweet chestnut.

Any intimate mixture of such species should, however, be avoided, as they almost always lead to difficulties. Mixtures of larch with sweet chestnut ; Scotch pine and Corsican pine; or Scotch pine and Weymouth pine are good mixtures sylviculturally if the crop is to be cut down fairly early, say at about fifty years of age, but Weymouth pine is not a very valuable species to plant, and is very subject to disease.

Oak has often been planted in alternate lines with conifers, the latter being nurses to the oak which was to form the permanent crop. This method seldom gives good results. If the conifers are cut out when they begin to top the oaks, the 
latter are left so far apart that they grow short and branchy. If, on the other hand, the conifers are left standing too long, the oaks are suppressed and the wood becomes practically a coniferous one, the so-called permanent crop being ruined. It is better to do without nurses. When oak is planted pure and dense, each tree nurses its neighbour, and if the wood is underplanted with beech, a far better crop is eventually obtained than under the system of planting with conifer nurses.

Although mixed woods are recommended wherever the area is extensive, yet pure woods are quite admissible under certain circumstances, more especially if the species is a soil improver; thus pure woods of beech, hornbeam, spruce, silver fir, and Douglas fir may be grown if desired, though the conifers are more likely to suffer from insect and fungoid attacks. Coniferous woods are often found pure in nature, but in such places the soil and climate are usually thoroughly suited to them and they therefore do not suffer so much from insects and fungi as they do when artificially grown pure in less favourable spots, and if we plant them pure, we must understand that a risk is taken.

Scotch, Weymouth, Austrian and Corsican pines, and sweet chestnut are capable of preserving the fertility of the soil up to thirty or forty years and may therefore be grown pure, provided they are to be cut at this age to provide pit-wood or other small produce.

Other cases where pure woods are allowable are, when the soil is obviously suited for one species only, e.g. Scotch pine on poor, dry, sandy soils; or when only one species is saleable at present, and when it is unlikely that other species will be saleable in the future.

Ash, elm, maple, sycamore, poplars, and tree willows are never found in large masses in natural woods, and they do not flourish in artificially formed pure woods. They should, therefore, always be scattered here and there in small groups in woods consisting chiefly of other species. 


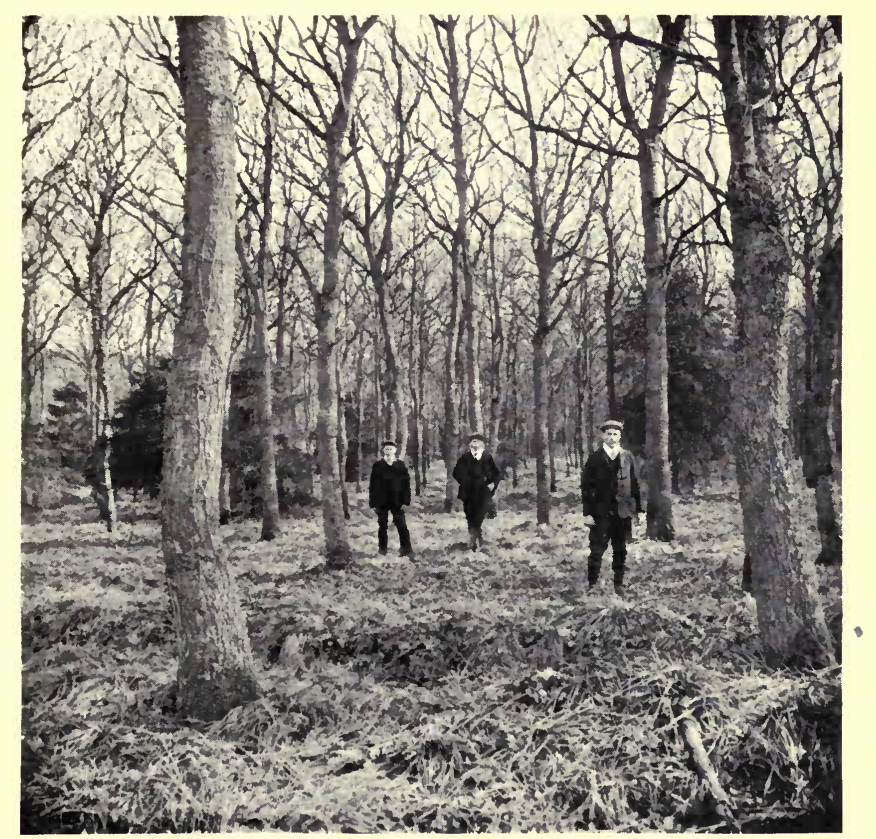

Oak aged 50 years, height 43 feet, volume 1268 cubic feet per acre. Much over-thinned but still worth underplanting. (The wood appears more open in the photograph than is really the case.) 
a 


\section{CHAPTER IV}

\section{NURSERY MANAGEMENT}

IN existing woods one often finds young plants of oak, ash, sycamore, and other species springing up where they are not wanted, and these may be dug up and planted in other places. Usually, however, they do not give good results, for two reasons-firstly, because they have been growing in the shade of older trees and are often partially suppressed, and do nct flourish when transferred out into the full light; secondly, because their roots have not been trained to withstand the operation of transplanting. As a rule the plants are so scattered that the cost of digging them up, and of carriage, is excessive.

Young plants may be obtained by purchase from public nurseries or they may be raised in home nurseries. The latter procedure is strongly recommended where the planting is on an extensive scale, as the plants can be raised very cheaply and usually prove more satisfactory than bought plants. As one can choose the day for taking the plants out of the nursery and can plant them without delay there are usually fewer failures in the plantation, while when sent by rail the roots may dry up if there is any delay in delivery.

When, however, planting is done at irregular intervals, so that a steady supply of plants is not required, or when it is only carried out on a small scale, it is best to purchase plants from one of the well-known nurserymen.

On many estates it is the practice to purchase one or two year old seedling plants and to grow these on for a few years in the home nursery. This is a good system, especially for 
the rarer exotics, though, if a nursery is kept at all, it would not add much to the work to grow the plants from the seed. This is a perfectly simple business with all the common forest trees and presents no difficulty.

Purchase of plants from public nurseries. When purchasing plants the woodman should, if practicable, visit the nursery, from which he proposes to get his plants, in the summer preceding the planting season; he will thus see the plants in full leaf and can be sure that they are well grown and healthy. He should have a few samples dug up and should see that the roots are well shaped, with plenty of fibrous roots, and that they are not all on one side. The plants should be wellproportioned, with well-formed buds, and they should not be drawn up and lanky.

If a visit cannot be made to the nursery, samples should be obtained before purchasing.

If the situation to be planted is at a high elevation or in an exposed spot it will be as well to obtain plants from a nurseryman whose nurseries are situated in a similar place, preferably from the north of Great Britain, taking care that the plants have been actually grown in the nursery from which they are ordered, and that they are not second-hand ones from elsewhere.

On arrival of the plants they should be unpacked, examined and counted, watered, and at once planted; if this cannot be done immediately, they must be 'heeled in'. A trench is dug, the roots are placed in this and are well covered with soil. Should the plants arrive during a hard frost they should be placed, just as they are, in a shed and should not be unpacked till the frost comes to an end.

Home murseries. These may be temporary or permanent. A temporary nursery is one laid out roughly, in the centre of the area to be planted, strips being dug up about one foot wide and two feet apart in which young plants are planted three or four inches apart. When these are large enough 
they are planted out, leaving plants at about 4 feet apart throughout the temporary nursery to form a crop.

Such a nursery has certain advantages as follows :-

1. The plants are trained on the soil and situation where they are to be permanently planted.

2. At the time of planting they have to be carried a short distance only.

3. The area of the nursery has not to be planted again, but is already stocked with a crop.

4. It is cheap, as fencing is unnecessary.

5. It saves the cost of a permanent nursery when but little planting is done.

This method has been tried in the Forest of Dean for some years, but it has been found that, unless a large expenditure is incurred in weeding, many plants are lost. Moreover, as the soil is not well worked after planting, it is hard to dig up the plants without doing great damage to the roots. In fact, the disadvantages have been found to outweigh the advantages and the system is now being given up in favour of permanent nurseries.

Permanent nurseries cost more to prepare, but they yield much better plants and can be used for a great number of years; the saving on the cost of the plants as compared with bought ones soon repays the cost of forming the nursery.

Preparation of a home mursery.

Choice of site. The following points require consideration:-

I. The nursery should be near the centre of the forest, so that the plants can easily be carted to all parts. In extensive forests there should be several nurseries.

2. It should be near a woodman's lodge, so that it can easily be looked after.

3. It should be near water, which should, if possible, be 
above the nursery, so that it can flow down to any part of the area in pipes laid down for the purpose.

4. It should be near a road or ride to make cartage easy.

5. It should be on a gentle slope to ensure good drainage.

6. It should not be in a deep shallow valley where frost is likely to be bad. A fairly open position sheltered by surrounding woods, but open to the free circulation of air, is best. Regarding aspect, probably sheltered north or northwest aspects are the best, as cold east winds do much harm on an east aspect, and the soil dries up too quickly on a south aspect. Moreover, south and east aspects receive sunlight early, and thaws after a night of frost will be too rapid. Too much shelter, however, is not good.

7. The soil should, if possible, be a light sandy loam, free from stones, as this is easily worked. It should not be too fertile or the plants will suffer when transplanted to less fertile soils. It should be of fair depth, because a shallow soil dries up quickly; from 18 inches to 2 feet is sufficient. If there is a choice only between a very light and very heavy soil, the light one is preferable.

The area of the nursery depends on the amount of planting to be done; as a general rule, where four year old plants are used, which are left two years in the seed-bed and two years in the nursery lines, an area of four or five acres of nursery is required for every hundred acres of land to be planted annually.

Formation of the mursery. The shape should be a square or rectangle, as this is cheapest to fence; and the beds are more easily laid out without waste of ground, and look neater. The nursery should be well fenced with a good wire fence, with rabbit netting attached, to keep out all cattle and ground game ; if on an exposed situation, an evergreen hedge should be planted within the wire fence to give shelter against cold winds. Draining should not be necessary, as land wet enough to require draining should not be chosen; if, however, this 
must be done, it is advisable to lead the drains into a well at the lowest point of the nursery, whence the water can be raised by a pump for use in hot summers. As soon as the land is fenced the whole area should be carefully trenched to a depth of 18 inches to 2 feet, removing all stones and roots and levelling the surface at the same time. If the soil is of fair quality throughout, the top and bottom soil may be mixed while trenching is going on, but if the bottom soil is poor it will be best to leave it underneath, keeping the best soil on the top, as it is not desired to encourage young plants to grow deep roots. The trenching should be done during the summer, leaving the ground rough for the frost to pulverize the soil during winter. It should be dug over again and harrowed in spring and is then ready to be stocked.

With regard to the necessity for manure, as a general rule all strong manures should be avoided, as the young trees should not be forced. All that is necessary is to use a plentiful supply of well-decayed humus or leaf-mould. Well-rotted humus from ditches in the woods should be carted on to the ground and should be dug in at the time of trenching, and this may be repeated in future years whenever a piece of land is vacant. If this is done regularly no other form of manuring will be necessary, though it is as well to give a dressing of lime when putting on the humus, if the soil is deficient in this mineral. A crop of lucerne or other leguminous plant, grown on the area and ploughed or dug in, will enrich the soil considerably; this is often a good way of improving poor sandy soil before it is used as a nursery, if humus is difficult to obtain in large quantities.

To collect humus a ditch may be dug outside the nursery, and into this all dead leaves and rotting humus from the ditches in the forest may be thrown, together with all weeds from the nursery. These can then be allowed to rot and can easily be thrown over into the nursery when required. Fresh humus must not be mixed with old well-rotted stuff, but 
should be placed in a different part of the ditch to mature for two years. Care must be taken not to throw flowering weeds into the ditch ; these should be burnt to destroy the seeds. An occasional dressing of lime to the dead leaves in the ditch will hasten their decomposition and will improve the manure.

Laying out the mursery. The area should be divided up by paths into squares or rectangles of about one quarter of an acre each. In a small nursery of about one acre a cart road is seldom necessary, but if the area is large a good cart road Io feet wide should be made down the centre with a turning space at the end, and paths 3 feet wide should then be made at right angles to the road, so that a wheelbarrow can be taken to all parts. These paths may be lined with an edging of privet to prevent the soil falling on to them, or a line of stones may be used for this purpose. The paths should be made hard with small stones and gravel.

About one-tenth of the area of the nursery will be required for seed-beds, and this should be further divided into beds about 3 feet in width with a sufficiently wide footpath between them. A bed 4 feet wide is difficult to weed, and narrow beds are therefore preferable. The rest of the area will be used for nursery lines and the parts devoted to this work need not be further subdivided.

The nursery having been laid out, it should be stocked by purchasing one and two year old seedlings of the species required, which should be lined out in nursery lines, and by sowing seed.

Sowing the seed-beds. The soil on the seed-beds must be brought to a fine state of division by raking. If the seed is to be sown broadcast a wooden rake without teeth is used to draw away the top soil to the sides, the amount drawn away depending on the depth to which the seed must be sown. The seed is then sown equally over the surface and the drawn up earth is pushed over the bed with the wooden rake so as to. 
cover the seeds. A light roller should then be passed over the bed.

If the seed is to be sown in drills these should be made to run across the bed to facilitate future weeding. A drill is made with a small hoe, or by pressing the edge of a board into the soil, other drills being then made parallel to the first at the proper distance apart.

When the seed is sown it is covered by drawing soil over the drills with a rake, or by sprinkling fine earth on the surface.

Sowing in drills is more satisfactory than broadcast sowing, as the plants have more light and root-space, but it takes up a lot of ground and broadcast sowing is therefore usually preferred. In both cases care must be taken not to sow too thickly, though, if seedlings are to be pricked out at the end of one year the sced may be sown more thickly than if they are to remain two years in the seed-bed.

The following table is compiled from Schlich's Manual of Forestry, Nisbet's The Forester, and Simpson's Estate Nursery, and the figures have been checked as far as possible by the author during six years' work in the Dean Forest nurseries. It gives the season to sow, the depth of covering, the number of plants expected from one pound of seed, and other useful information. 


\begin{tabular}{|c|c|c|c|c|c|c|c|}
\hline \multirow[t]{2}{*}{ Species. } & \multicolumn{2}{|c|}{$\begin{array}{c}\text { Price of I lb. } \\
\text { of seed } \\
\text { (1910) }\end{array}$} & \multirow[t]{2}{*}{ 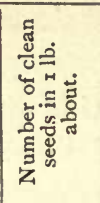 } & \multirow[t]{2}{*}{ 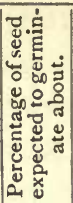 } & \multirow[t]{2}{*}{ 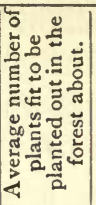 } & \multirow{2}{*}{$\begin{array}{l}\text { Season when } \\
\text { seed should } \\
\text { be collected. }\end{array}$} & \multirow[t]{2}{*}{ Season to sow. } \\
\hline & Home. & Foreign. & & & & & \\
\hline Ash & I/- & $3 d$. & 7,000 & 65 & 2,300 & Oct., Nov. & Ap. of 2nd year \\
\hline Alder & $1 !-$ & $3^{d}$. & 300,000 & 25 & 37,000 & $\begin{array}{l}\text { Oct., Nov., } \\
\text { Dec. }\end{array}$ & April \\
\hline Beech & $1 / 4$ & I I $d$. & 2,000 & 50 & 750 & Oct., Nov. & Dec. or March \\
\hline Birch & $1 ! 4$ & $4 d$. & 800,000 & 20 & 80,000 & $\begin{array}{l}\text { July, Aug., } \\
\text { Sept. }\end{array}$ & $\begin{array}{l}\text { As soon as } \\
\text { gathered }\end{array}$ \\
\hline Elm & $1 / 4$ & $8 d$. & 60,000 & 30 & 9,000 & May, June & " \\
\hline Hornbeam & $1 / 4$ & $4 d$. & I 5,000 & 65 & 7,000 & Oct. & Ap. of 2 nd year \\
\hline Oak & 1/- & $4^{d}$. & I 30 & 65 & $6_{5}$ & Oct., Nov. & Nov. or April \\
\hline Sycamore & $I / 4$ & $4 d$ & 5,000 & 50 & 2,000 & Sept., Oct. & Oct. or March \\
\hline Sweet Chestnut & $1 /-$ & $9^{d}$ & I I 5 & 60 & 60 & Oct., Nov. & April \\
\hline Austrian pine & $4 / 3$ & $2 /-$ & 25,000 & 70 & 6,000 & $\begin{array}{l}\text { Nov., Dec. } \\
\text { Jan. }\end{array}$ & April \\
\hline Corsican pine & $4 / 9$ & $4 / 6$ & 32,000 & 70 & 7,500 & & " \\
\hline Scotc & $4 / 3$ & $2 / 5$ & 75,000 & 60 & I 5,000 & Dec., Jan. & , \\
\hline Weymouth pine & $8 /-$ & $5 /-$ & 25,000 & 40 & 5,000 & Sept., Oct. & , \\
\hline $\begin{array}{l}\text { Silver fir } \\
\text { Douglas fir }\end{array}$ & $1 / 3$ & $3^{d}$. & 10,000 & 40 & 2,000 & Sept., Oct. & $"$ \\
\hline Douglas fir & $20 /-$ & $11 /-$ & 40,000 & 50 & 10,000 & Oct. & $"$ \\
\hline In & $3 / 6$ & I/- & $65, \mathrm{coo}$ & 65 & 14,000 & $\begin{array}{l}\text { Oct., Nov., } \\
\text { Dec. }\end{array}$ & $"$ \\
\hline $\begin{array}{l}\text { Larch } \\
\text { Japanese larch }\end{array}$ & $\begin{array}{r}2 / 6 \\
17 / 6\end{array}$ & $\begin{array}{r}1 / 9 \\
16 /-\end{array}$ & $\begin{array}{r}70,000 \\
100,000\end{array}$ & $\begin{array}{l}35 \\
35\end{array}$ & 8,000 & , & " \\
\hline & & 80 & & 35 & 10,000 & " & $"$ \\
\hline
\end{tabular}

This table must be used only as a guide, as the figures vary so much under different conditions.

The price of seed given above is taken from two catalogues for I9IO, one set from an English price list, and the other from a foreign list; the cost of carriage would have to be added to the price of the foreign seed. The price varies from year to year according to the crop. Seed can often be collected in the home woods much more cheaply; beech mast, for instance, can be collected for $4 d$. per pound, and acorns for Id. per pound.

The number of seeds in one pound, and the germinative percentages vary considerably according to the quality of the 


\begin{tabular}{|c|c|c|c|c|}
\hline $\begin{array}{l}\text { Width } \\
\text { between } \\
\text { drills. } \\
\text { Inches. }\end{array}$ & 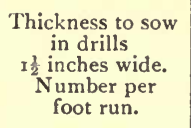 & $\begin{array}{l}\text { Thickness to sow } \\
\text { when broadcast. } \\
\text { Number per } \\
\text { square foot. }\end{array}$ & $\begin{array}{l}\text { Depth of } \\
\text { soil covering. } \\
\text { Inches. }\end{array}$ & Remarks. \\
\hline 12 & 30 & 80 & $\frac{1}{2}$ & $\begin{array}{l}\text { Seed is mixed with sand } \\
\text { and kept till and spring. }\end{array}$ \\
\hline 6 & Thick & Thick & Sprinkling & \\
\hline $\begin{array}{l}9 \\
6\end{array}$ & $\begin{array}{l}\frac{\mathrm{I}}{4} \text { inch apart } \\
\text { Thick }\end{array}$ & $\begin{array}{l}70 \\
\text { Thick }\end{array}$ & Sprinkling & Time of ripening depends \\
\hline 8 & Thick & Thick & " & $\begin{array}{l}\text { on the weather. } \\
\text { Common elm seed should } \\
\text { be got from abroad. }\end{array}$ \\
\hline 9 & $\stackrel{30}{30}$ & 80 & $\frac{1}{2}$ & Treat like ash. \\
\hline 12 & ¿ inches apart & 40 & $I \frac{1}{3}$ & If l-ent over winter miv \\
\hline I 2 & $3 \circ$ & 80 & $\frac{3}{4}$ & $\begin{array}{l}\text { If kept over winter mix } \\
\text { with dry sand. }\end{array}$ \\
\hline 12 & 2 inches apart & 30 & 2 & $\begin{array}{l}\text { Sow with point downwards. } \\
\text { Foreign seed is best. }\end{array}$ \\
\hline 9 & $4^{0}$ & 200 & $\frac{1}{2}$ & \\
\hline 9 & 40 & 200 & $\frac{1}{3}$ & \\
\hline 9 & 50 & 300 & $\frac{1}{4}$ & \\
\hline $\begin{array}{l}6 \\
6\end{array}$ & $\begin{array}{l}70 \\
60\end{array}$ & 300 & , & \\
\hline 9 & 50 & $\begin{array}{l}300 \\
300\end{array}$ & $\ddot{,}$ & \\
\hline 6 & 50 & 300 & ", & \\
\hline 9 & $\begin{array}{l}60 \\
60\end{array}$ & 300 & , & \\
\hline 9 & 60 & 300 & ", & \\
\hline
\end{tabular}

seed; while the number of plants finally obtained fit to go into the forest at three or four years old, depends greatly on the weather and treatment. A large number of those that germinate will be lost through overcrowding in the seed-beds, and many plants are, for onc reason and another, not worth putting out. Bad plants, or culls, should always be thrown away.

With regard to the thickness of sowing, it is a mistake to have the seed too crowded on the ground, as the seedlings get drawn up and have insufficient root space. The figures given above are on the assumption that the seedlings will remain two years in the bed; if they are to be lifted at the end of the first year, or if a test has shown that the seed has a bad ger- 
minative power, it may be sown rather thicker than is recommended above.

Sowing should only be carried out when the soil is dry and in a fine state of division.

Germination is hastened if the seeds are kept wet for some time before sowing, twelve hours is enough for most species, but larch seed should be kept in a wet state for five or six days. It is also a good plan to roll the seeds in red lead while still wet, as this will, to a large extent, prevent their being eaten by mice and birds; and when thus coloured red it is easier to see that they are not sown too thickly. The seeds should not be sown till the red lead has become fairlydry, so that they do not stick together and fall in a lump.

Quality of seeds. It is very important to sow only good seed. As a general rule it is best to collect the seed of broad-leaved species from the home woods, and, if this is done, it should only be collected from well-grown, middle-aged trees. Seeds of common elm and of sweet chestnut are best obtained from abroad, as they seldom ripen in English woods. Elm, in fact, is usually propagated from suckers and not from seed.

The preparation of conifer seeds is a somewhat troublesome business, and it is generally best and cheapest to buy them from some firm of good reputation. If collected in the home woods the cones should be laid on shelves in a warm room to open.

A sample of the seeds to be sown may be tested in the following way. Place a piece of damp flannel across a dish with one end in another dish full of water. Put 100 of the seeds to be tested on this flannel and cover them with a second damp flannel. Keep them in a warm room at an even temperature. Examine daily and remove all seeds as they germinate, carefully counting the number. Seed may be considered good if a carefully carried out test shows that the percentage given in the table have germinated. 
Time of sowing. Wych-elm seed should be sown as soon as collected in June. Birch seed is usually collected and sown in August. The seeds of hornbeam, ash, hawthorn, lime, yew, and holly should be mixed with sand in a pit and should be sown along with the sand in the second spring after collection. The sand and seed in the pit should be turned every three months. This treatment is necessary to rot off the outer husk of the seed, and it is only a waste of space to sow direct on the seed-bed, as the majority of the seeds will not germinate till the second year. Large seeds like those of oak and chestnut may be sown in autumn, but they are then liable to be eaten by mice or birds. These seeds and those of all other species not mentioned above, are best kept till the following spring in an airy loft, being turned every now and then; they are then sown in April or the beginning of May. Old seed which has been in store for longer than the period indicated above should not be used, as it will have lost its germinative power.

Pricking out. In certain cases when the seedlings have been in the seed-beds two years they are transplanted direct into the woods. Such cases are few, and usually the plants are moved or pricked out into another part of the nursery and are placed in what are called nursery lines; the plants themselves being now called transplants.

Certain distinctive names are given to plants according to the number of years they have stood in the seed-beds and in the nursery lines. Thus 'two-year-two' plants are those which have been two years in the seed-bed and two years in the nursery lines; this sized plant is probably the most commonly used for planting into the woods. If three years old plants are used for planting out, one-year-two plants are stronger and have a better root system than two-year-one plants, as one year in the nursery lines is not sufficient for the plant to take advantage of the increased space given to it.

The reason for transplanting from the seed-bed to the 
nursery lines is to give each plant room to grow ; the operation causes the plants to form bushy fibrous roots with which they are more successfully planted into the woods.

When a bed of seedlings is to be pricked out the soil should be well loosened by using two forks, one on each side of the bed, and the seedlings are then carefully drawn out by hand. The soil should not be shaken off the roots, as if this is done all the root hairs are torn away; there is no object in removing the little earth which clings on, as the plants have only to be carried a short distance to another part of the nursery. The seedlings, unless they are to be planted at once, should be promptly heeled in, in a shady place, their roots being well covered with soil.

The most important point is to see that the roots never get dry, therefore pricking out should be done in moist weather, or, if the day is dry and a wind is blowing, the roots should be dipped in water or liquid mud before being heeled in. Neglect of this precaution may cause the death of a large number of plants, whereas if carefully done there is no reason why any should die.

To plant into nursery lines, the ground having been well dug over, a garden line is put down across the area and a trench is dug out along it with a vertical side to a depth of at least ten inches. Against this side the plants are placed at the proper distance apart and with their roots going straight downwards. A handful of earth is pressed against the plant to hold it in position, and when the whole line is completed the trench is filled up and the plants are gently firmed in with the foot. The garden line is then moved nine or twelve inches and the process is repeated.

In many cases the trench is made too shallow and the roots are therefore doubled up ; this must be avoided at all costs.

While being pricked out the plants are often pruned, but pruning should be reduced to a minimum; a damaged or extra long root or a double leader may be pruned off with 
a sharp knife, but otherwise the less pruning is done the better, as disease often enters the wounds formed.

Pricking out may be done in any open weather during autumn and spring, the latter being the most favourable time. Care must be taken not to plant too deeply, as this is a common cause of failure ; the plants should be placed in the ground to the same depth as they stood before.

The best general distance at which to place seedlings in the nursery lines is 9 inches by 4 inches, but very quick growers may be put in at 12 inches by 6 inches. As the plants will be taken out again in one or two years' time it is not necessary to give a larger space, and it is very important to get as many plants as possible into the nursery, as the cost of weeding per thousand plants is thus reduced; 9 inches between the rows just gives a man room to put his feet down and to work a hoe.

If very large plants, six or more years old, are required for planting out they must be transplanted more than once in order to keep the root system bushy and fibrous. Transplanting of such plants should be done every two years. If, owing to want of ground, or for any other reason, plants cannot be transplanted at the proper time, they should be undercut. This is done by pushing in a sharp spade in such a way as to cut off the lower roots. This retards growth and causes new fibrous roots to be formed, but the operation should only be substituted for transplantation in case of absolute necessity.

Tending the nursery. The young plants in the seed-beds and nursery lines must be protected against various dangers which threaten them. The chief are frost, drought, drying winds, weeds, destructive birds, mice, moles, squirrels, hares and rabbits, injurious insects-of which the cockchafer grub is the worst-and injurious fungi, which cause disease. Measures to be taken against these pests are dealt with in Chapters VIII, IX, and X. 


\section{CHAPTER V}

\section{SOWING AND PLANTING IN THE FOREST}

\section{SowING}

IN some cases it is possible to sow the seeds directly in the woods; but this should not be attempted with seeds which are expensive to buy, or when there is a heavy growth of weeds, or where the species is a very slow grower, as in these cases the final cost is often more than the cost of planting large plants. Whereas in a nursery the seeds and seedlings can be protected from the numerous dangers to which they are exposed, in a forest nothing can be done except at great cost. Birds and mice may eat up a considerable amount of seed, and a strong growth of weeds will smother a large quantity of the seedlings, unless the ground is continually weeded, which is an expensive work. If, however, a piece of agricultural or other land clear of weeds is to be afforested it may be possible to sow direct ash, sycamore, birch, and pine, which grow rapidly, and in some cases oak, beech, and chestnut. Autumn is the season adopted by nature, as a rule, for the shedding of the seed, but in artificial sowings spring is a better period, because when sown in spring germination soon follows, while autumn-sown seed remains dormant all the winter, giving time for mice and birds to eat large quantities.

If sowing is adopted, the general method is the same as in the nursery, but the ground is only partially prepared, to reduce the cost. Strips 18 inches to 2 feet wide and from 3 to 4 feet apart should be ploughed or dug up; the soil should be well pulverized and the seed should then be sown in these strips, and covered with the proper amount of soil. 
When the seedlings have appeared the after management consists chiefly of keeping down the weeds. On hilly land the strips should follow the contour and should not run up and down the hill, as in this case a heavy rainfall may wash soil and seeds to the bottom of the strip.

Where the surface is turfy, acorns or chestnuts may often be successfully sown by lifting up a piece of turf with a spade and throwing in two or three seeds under the turf, which is then trodden down. This system has been successfully carried out in some parts of Dean Forest.

Where the soil is very thin and rocky, it is often impossible to find enough soil for planting, and in this case sowing is practically the only possible method of forming a crop.

As a general rule planting gives more favourable results than sowing, and the latter method is only likely to be carried out in a few specially favourable situations.

\section{Planting}

Both seedlings and transplants can be used for planting in the woods, and it depends on local circumstances which kind of plant should be preferred. Seedlings are much cheaper, and will sometimes stand the severe operation of transplanting better than larger plants, but on the other hand they are liable to be smothered by a rank growth of weeds unless a heavy expenditure is incurred in cutting this back annually for three or four years. In our moist climate, as a general rule, transplants are the best to use, preferring ordinarily twoyear-two or one-year-two plants, which are usually from one and a half to two feet in height. Larger plants cost a good deal more, and very often a large proportion will fail, while three or four year old plants, according to species, are generally large enough to rapidly outgrow any ordinary growth of bracken, bramble, and other weeds.

Two year seedling pines may be used for planting up sandy soils, and seedlings of other species may also be used where 
there is not much danger of their being smothered. The woodman must decide for himself, after considering the local circumstances, which plants are best.

Plants either with balls of earth or with naked roots may be used, but the former are expensive to move, and in the vast majority of cases naked rooted plants are preferable.

Season for planting. Planting must be carried out in autumn or spring, as the plants are at rest in these seasons, and both temperature and moisture of air and soil are then favourable.

There are points in favour of both autumn and spring planting. If planted in autumn the trees get a good hold of the ground before growth commences, and may start growing rapidly early in spring ; on the other hand the trees, especially conifers, may be blown about by high wind, and may be damaged by frost and snow. If planted in spring they escape this damage, and, if the weather is damp, the trees become established rapidly. Should, however, the weather be dry for a month after planting, the failures may be numerous. If there are a very large number of trees to be planted it would be difficult to get them all into the ground before the end of April if the work is only begun in spring. In practice, therefore, planting should be carried on in all open weather from November to April I5, avoiding January and February, and commencing with the broad-leaved deciduous species and larch in autumn, and ending with the evergreen conifers in spring. Douglas fir succeeds best when planted in April. Corsican pine, which forms very few roots, is a difficult tree to transplant, and does best when planted as two year old seedlings in the last half of October or April. No planting should be done when there is a frost or cold cutting wind.

Lifting plants and transit to the woods. From the time the plants are lifted in the nursery till they are safely planted in the wood every care must be taken to prevent the roots becoming dry, as on this depends to a great extent the success 
of the operation; unfortunately sufficient care to see to this is not taken in all woods. All operations should take place as far as possible on damp cloudy days, but if it is absolutely necessary to lift or plant on sunny days, or when a dry wind is blowing, the roots of the plants should be dipped into water and this should be repeated whenever it is necessary. This simple precaution is easy, it costs nothing, and, if carefully carried out, it will prevent many failures.

Plants should be lifted by two men using forks one on each side, the plant being carefully drawn out when the soil is well loosened. It may be lightly shaken to remove the greater part of the earth, but this must not be done violently or the small fibrous roots will be lost. As soon as fifty or one hundred plants have been lifted, they should be tied into a bundle, taking care not to bruise the bark, and this should be heeled in. When sufficient bundles have been prepared they should be carted to the woods, if possible in the evening after the sun has set, but if moved in the daytime they should be well covered over with mats or branches. On arrival they should be at once heeled in, as near as possible to the ground to be planted and in a shady place. If they are not likely to be put out for some days it is best to open the bundles and to heel in the plants in thin layers in such a way that the roots are in close contact with the soil. If bundles of plants are left heeled in for some time, the plants in the middle of the bundle often fail, as, not being in contact with the soil, the roots dry up.

Only a few plants should be carried to each planter at a time, sufficient for him to plant during the next fifteen minutes or so; if he is given a large number he will probably lay them out in the holes, and those which are to be planted last may get dry before he comes to them.

Distribution of the plants. The trees should be planted, where possible, in regular lines as this facilitates weeding later on, but the lines need not be marked out perfectly straight 
with a garden line, though this is advisable if the plantation is near a much frequented road or ride, as it looks tidier. A fairly experienced man will be able to plant in sufficiently straight lines if he occasionally checks his distance with a stick cut to proper length. When planting up areas from which a previous crop has been cut it is often impossible to space the plants regularly owing to the stumps of the old trees, and the plants must be put in wherever there is room for them.

The most common forms of distribution are the square, where the distance between the lines is equal to the distance between the plants in a line, four plants thus standing in the four corners of a square; equidistant lines, in which case the plants stand closer together in the lines than the distance between the lines; and the triangle, when the plants stand at the three corners of an equilateral triangle, the distance between the lines being rather less than the distance between the plants in a line, and the plants in one row are opposite the spaces in the next row.

When once the young wood has formed thicket there is very little difference between these various forms of distribution, and for all practical purposes square planting is satisfactory and is the easiest to carry out.

If a mixed wood has been decided on, the planters should be instructed how to make the mixture; if it is to be by groups the woodman should mark out with stakes the areas where the different species are to be placed.

Density of planting. The number of trees which should be planted on an acre depends on the cost, the species to be planted, the size of plants used, the soil and climate, the object of the plantation, and the probable market for small poles.

The general object should be to obtain a complete cover over the ground within from five to ten years and therefore quick growing light-demanding trees can be planted further apart than slow growing shade-bearers. Species which tend to branch heavily, such as oak and Scotch pine, should be, 
however, planted rather densely in order to prevent the development of branches. In a fertile locality plants may be at greater distances than on poor soils or at high elevations, as the trees grow more quickly. Small plants must be planted more densely than large ones, as they take longer to form a thicket. Where the object is to produce small poles, or if small poles can be readily sold, it will usually pay to plant more densely than where only large timber is saleable.

Of course only a small proportion of the trees planted will come to maturity, but those trees which are crowded out will have done the work required of them, for they will have competed with the better trees, and will have helped to force them to grow tall, straight, and free from branches. Moreover, after the twentieth year such trees will be cut out in the thinnings, and will often give a good revenue. Taking all things into consideration, the following distances are the most favourable on average soils where the intention is to grow clean timber of fair size. On very favourable soils the distance may be greater, while on poor soils or at very high elevations it should be rather smaller.

Spruce, Douglas fir, ash, larch, and Weymouth pine, where plants from $\mathrm{I} \frac{1}{2}$ to 3 feet high are used, should be planted 4 feet by 4 feet or 2,722 plants per acre.

Oak, beech, Scotch pine, Corsican pine, and Austrian pine, of the same size, should be 3 feet by 3 feet or 4,840 plants to the acre.

Where seedlings are used, the distance apart should be $2 \frac{1}{2}$ feet or $2 \frac{3}{4}$ feet at most.

Where it is absolutely essential to keep the cost down to the lowest limits, these distances may be slightly increased. Larch, Douglas fir, and ash may be put in at 5 feet or even 6 feet apart, and the other species at 4 feet, but 6 feet should ordinarily be the greatest distance apart at which trees should be planted, and this only very exceptionally.

The number of plants required for a given area, by square 


\section{SOWING AND PLANTING IN THE FOREST}

or line planting, may be found as follows: Divide 43,560 (the number of square feet in an acre) by the product obtained by multiplying the distance between the lines by the distance between the plants in the lines, and multiply the result by the number of acres. Thus if ro acres are to be planted at 4 feet by 4 feet the number of plants required is :-

$$
\frac{43,560}{4 \times 4} \times 10=27,220 \text {. }
$$

The number of plants required per acre for planting at different distances apart in square and triangle planting is as follows :-

\begin{tabular}{|c|c|c|c|c|c|}
\hline \multirow{2}{*}{$\begin{array}{c}\begin{array}{c}\text { Planting } \\
\text { distance. }\end{array} \\
\text { Feet. }\end{array}$} & \multicolumn{2}{|c|}{$\begin{array}{l}\text { Number of trees } \\
\text { per acre. }\end{array}$} & \multirow{2}{*}{$\begin{array}{c}\begin{array}{c}\text { Planting } \\
\text { distance. }\end{array} \\
\text { Feet. }\end{array}$} & \multicolumn{2}{|c|}{$\begin{array}{l}\text { Number of trees } \\
\text { per acre. }\end{array}$} \\
\hline & Square. & Triangle. & & Square. & Triangle. \\
\hline I & 43,560 & 50,312 & 4 & 2,722 & 3,144 \\
\hline $\mathrm{I} \frac{1}{2}$ & 19,360 & $22,36 \mathrm{I}$ & $4 \frac{1}{4}$ & 2,411 & 2,785 \\
\hline 2 & 10,890 & 12,578 & $4 \frac{1}{2}$ & 2,151 & 2,484 \\
\hline $2 \frac{1}{2}$ & 6,969 & 8,049 & $4 \frac{3}{4}$ & 1,930 & 2,229 \\
\hline $2 \frac{3}{4}$ & 5,760 & 6,653 & 5 & 1,742 & 2,012 \\
\hline 3 & 4,840 & 5,590 & $5 \frac{1}{2}$ & $\mathrm{I}, 440$ & 1,663 \\
\hline $3 \frac{1}{4}$ & 4,124 & 4,763 & 6 & 1,210 & 1,398 \\
\hline $3 \frac{1}{2}$ & 3,555 & 4,106 & 7 & 888 & 1,026 \\
\hline $3 \frac{3}{4}$ & 3,097 & 3,577 & 8 & 680 & 785 \\
\hline
\end{tabular}

The distance between the lines in triangle planting is as follows :-

\begin{tabular}{|c|c|c|c|c|c|}
\hline $\begin{array}{l}\text { Distance between } \\
\text { the plants. }\end{array}$ & \multicolumn{2}{|c|}{$\begin{array}{c}\text { Distance between } \\
\text { the lines. }\end{array}$} & $\begin{array}{c}\text { Distance beween } \\
\text { the plants. }\end{array}$ & \multicolumn{2}{|c|}{$\begin{array}{l}\text { Distance between } \\
\text { the lines. }\end{array}$} \\
\hline Feet. & Feet. & Inches. & Feet. & Feet. & Inches. \\
\hline $\begin{array}{l}2 \\
2 \frac{1}{2} \\
3 \\
3 \frac{1}{4} \\
3 \frac{1}{2} \\
3 \frac{3}{4}\end{array}$ & $\begin{array}{l}\text { I } \\
2 \\
2 \\
2 \\
3 \\
3\end{array}$ & $\begin{array}{l}8 \frac{3}{4} \\
2 \\
7 \frac{1}{4} \\
9 \frac{3}{4} \\
0 \frac{1}{4} \\
3\end{array}$ & $\begin{array}{l}4 \\
4 \frac{1}{2} \\
5 \\
5 \frac{1}{2} \\
6\end{array}$ & $\begin{array}{l}3 \\
3 \\
4 \\
4 \\
5\end{array}$ & $\begin{array}{r}5 \frac{1}{2} \\
10 \frac{3}{4} \\
4 \\
9 \frac{1}{4} \\
2 \frac{1}{2}\end{array}$ \\
\hline
\end{tabular}


Methods of planting. There are two common methods of planting, pit and notch planting, while occasionally special tools are used which form long narrow holes, this method being called peg-planting. In pit-planting, holes, which vary in size according to the size of plants used, are dug out with a spade; they are usually about ten inches deep and of about the same width for three or four year old plants. The soil taken out should be placed at the side of the hole in such a way that the poor soil is kept separate from the good. The bottom of the hole should be well loosened and the plant is then held in the middle of the hole by a boy, who arranges the roots in as natural a position as possible. The planter puts the finest and best earth round the roots, gently firming it down; then the rest of the hole is filled up to the level of the surrounding surface with the remaining earth, and finally the whole should be well trodden down. Where boys cannot be got a man working alone can do the work very efficiently after a little practice. In this case the man replaces about half the soil into the hole and then, holding the plant in his left hand, he makes a notch into the loose soil with the spade in his right hand and under his arm; he then puts in the plant, draws a little earth round it, and treads gently on it to steady the plant and fills in the hole as before. Holes are usually dug at the time of planting and are often made by a separate gang of men who do the work on contract.

When the soil is very stiff, it is sometimes preferable to dig the holes in autumn to allow the earth to be pulverized by frost during winter, and the planting is then done in spring. Wherever possible, however, this should be avoided, as the holes often get filled up with water or dead leaves and have again to be cleared when planting.

Pit-planting is undoubtedly the best method on most soils, as the ground gets fairly well worked; it is the only method which can be adopted when using transplants of four years old or more. It is, however, expensive. 
Notch-planting. This is usually performed with an ordinary spade, an $L$ or $T$ shaped cut being made in the ground. The handle of the spade being pressed downwards, the slit in the ground is opened, and a young plant is inserted. The spade is then withdrawn and the soil is firmed with the foot. This method has been largely used for planting one and two year seedlings of larch and pine, but it cannot be recommended, as the roots are usually bent over into an unnatural position and do not get a firm hold on the ground. Trees planted thus are very apt to get blown down later on, more especially as the method can only be carried out on light sandy soils; if tried on stiff soils the plantation is almost bound to be a failure, as the roots get compressed out of shape, and also because the slits in the ground often open out in dry weather. On light soils, free from stones, the advantages of notch-planting, cheapness and rapidity, may be retained, while getting rid of the defects of the system, by using Schlich's vertical notching spade; this is a heavy $V$-shaped spade which makes a vertical cut into the ground some Io inches deep. The plant is inserted by a boy with its roots going straight downwards, and the spade is then slantingly inserted two or three inches away, and being pushed backwards and forwards the hole is closed. The author planted with this spade 16,000 Scotch pine and 6,000 Corsican pine, two-year seedlings, in autumn 1905 , and in spite of the very dry summer of 1906, in July, 1907, there were 90 per cent. of the Scotch pine and 80 per cent. of the Corsican in a flourishing condition. During the short autumn days a man and boy, working together, planted between 900 and I,000 plants a day, and with a little more practice would have been able to improve upon this. If this spade is used on land covered with short growth of heather it is advisable to clear about one square foot of the surface round the planting spot with a hoe, as this enables the plants to get a start, and it is easier afterwards to discover failures.

Peg-planting. Where the soil is sandy, the surface free from 
weeds, and where small seedling plants are being used, it is sometimes possible to plant with a peg of iron or wood. The peg is driven into the soil and a plant is inserted into the hole with its roots straight downwards. The hole is closed in the same way as when using Schlich's vertical spade. The method is cheap and fairly satisfactory.

Mound-planting. When the ground is very wet or stiff, the young trees often get a better start when planted on small mounds instead of in pits. A few spadesful of earth are formed into a mound, the plant is inserted in the centre, and the soil is well pressed round it; the mound is then covered with turf or stones to protect the soil from sun or heavy rain. The method is only occasionally used, but is worth considering under certain circumstances.

Whatever the method of planting, it may be necessary to prune the plants, but this should be reduced to the minimum. An extra long or damaged root may be cut off, and if there are two leading shoots one may be removed. Each plant should be looked at separately and the necessary pruning done. Sometimes a handful of plants is taken and the roots are all cut off to a certain length; this practice should never be adopted, as excessive pruning often leads to disease which gets in through the wounds.

After the plantation has been formed it should be carefully looked after until the plants are well-established. The first care is to tread the young trees in firmly whenever they have been loosened by wind, as neglect of this precaution may cause great loss, and the rubbing of the stem against the soil may cause a wound in the bark which may afterwards lead to disease. This is specially necessary with autumn planting.

The year after planting, all failures should be filled up, and this should again be seen to in the second year. During the first three or four years weeds which are outgrowing the young plants must be cut back early in summer; when once the plants are above the weeds these latter do no harm, and they 
will shortly be killed by the increasing cover of the young wood.

Very often plantations of broad-leaved trees, especially oak and ash, seem to stand still and the trees do not commence to grow for several years. In this case the plants should be cut back to the ground in early spring, three or four years after planting. The stools will then form new shoots which will grow rapidly. When these are two years old, all except the best one on each stool should be cut away. The shoot left will then grow into a healthy tree.

Cost of planting. This varies according to the price of plants, the number per acre planted, the nature of the soil covering, the method adopted, and the cost of labour, hence no figures can be given which will apply in all localities. As a general rule the cost, excluding any draining, fencing, or cleaning of the land, varies from about $£ 2$ Ios. to $£ 7$ per acre, as indicated by the following examples :-

I. Notch-planting home-grown two-year seedlings of Scotch pine on sandy soil at 3 feet apart, 4,840 trees per acre, or say 5,000 to allow for unsuitable and damaged plants. $\begin{array}{llllllllll}5, \text { Notching } & & \ldots & \ldots & \ldots & \ldots & \ldots & 0 & 15 & 0\end{array}$

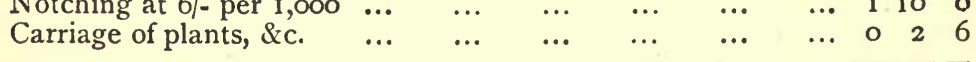
$\overline{£ 2 \quad 7 \quad 6}$

2. As above, using purchased plants.

5,000 plants at 9i- per I, o0o delivered at railway station \begin{tabular}{rrrr}
$\ldots$ & 2 & 5 & 0 \\
$\ldots$ & 1 & 10 & 0 \\
$\cdots$ & 0 & 2 & 6 \\
\hline & $£ 3$ & 17 & 6 \\
\hline
\end{tabular} $\begin{array}{llllll}\text { Notching at } 6 / \text {-per } \mathrm{I}, 000 & \ldots & \ldots & \ldots & \ldots & \ldots \\ \text { Carriage of plants, \&c. } & \ldots & \ldots & \ldots & \ldots & \ldots\end{array}$ 
2,800 plants at $12 /-$ per $1,000 \quad \ldots \quad \ldots$.. $d$.

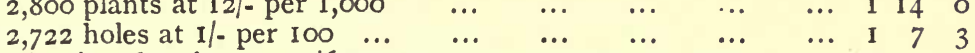

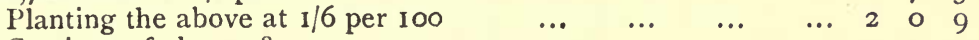

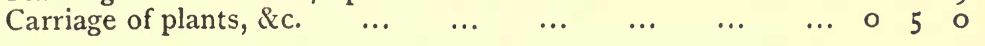

$$
£ 5 \quad 7 \quad 0
$$

4. As above, but using purchased plants of any species obtainable for $20 /$ - per I,000 delivered at railway station.

2,800 plants at $20 /$ - per 1,000

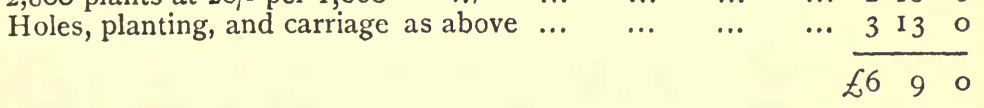

Some species, e.g. Douglas fir, are very expensive to buy from British nurseries. The cost can be reduced by buying the plants from abroad, or by growing them in the home nursery. The following estimates show this :-

5. One acre of Douglas fir at 4 feet apart using three years old plants purchased from British nursery.

2,80o plants at $£ 3$ per 1,000 Planting as above ... ...

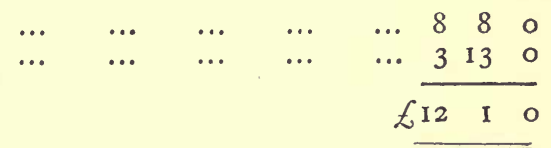

6. As above, but using foreign plants.

2,800 plants at $30 /$ - per 1,000 delivered $\ldots \quad \ldots$ Planting as above

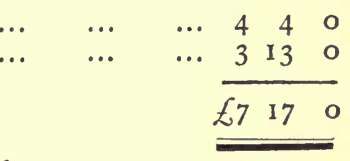

7. As above, but using home-grown plants.

2,800 plants at $15 /$ - per 1,000 (outside cost) Planting as above

$$
\begin{array}{rrrr}
\cdots & 2 & 2 & 0 \\
\cdots & 3 & 13 & 0 \\
\hline £ 5 & 15 & 0
\end{array}
$$

NoTE. - The cost of labour is assumed to be $3 /$ - per day per man.

The cost can be kept down by using home-grown plants, by planting rather farther apart, and by using small plants, but on 


\section{SOWING AND PLANTING IN THE FOREST}

the other hand it may often be necessary to spend a considerable sum on clearing the land, on fencing, and draining. These items must be kept as low as possible; the land may often be cheaply cleared by fire; fencing may sometimes be avoided by exterminating rabbits; and draining may often be reduced to a minimum by choosing a species which will succeed in wet land.

It is advisable to again warn the woodman that success in planting depends largely on two simple precautions:-keep the roots moist, and do not plant too deeply. 


\section{CHAPTER VI}

\section{TENDING OF WOODS}

WHEN the young woods have been successfully formed they must be carefully looked after throughout their life till they are ready to be cut down. They will always be liable to damage by insects and fungi, and also by fire, while during the first few years care must be taken to protect them from frost, drought, cold winds, and weeds. Measures to be taken against these dangers have already been mentioned in some cases, while further details will be found in Chapters VIII, IX, and $X$.

During the first ten years or so the chief matter of importance is to cut down inferior species like aspen, birch, and willows, which so often spring up naturally, as soon as they threaten to injure the more valuable species. If coppice shoots from a previously existing crop are found these must also be kept down wherever they are outgrowing the young trees. The best procedure is to work over all young woods in succession, cutting out all such forest weeds at intervals of three or four years till the woods enter the thicket stage. As long as the material cut is of no value and the proceeds do not pay the expenses, the operation may be called a cleaning; the material cut can be left lying on the ground. When once the wood has formed a thicket, usually between the twelfth and fifteenth year, it should be left alone till the lower branches begin to fall off and the woods begin to enter the pole stage. As soon as this occurs regular thinnings commence; a thinning being a cutting made for the benefit of the remaining trees, while the produce cut is usually large enough to have some value. 
In the thicket stage each tree is struggling against its neighbour for light and root space, and a regular struggle for existence is set up during which the weaker trees fall behind, become gradually suppressed, and finally die. The better trees, being pressed upon by their neighbours, are forced upwards and grow tall, straight, and clear of branches; but if the struggle is too long continued, they may be forced too much and may become weak and lanky. If left to nature the struggle for existence goes on all through life, the weaker trees gradually dropping behind. The woodman steps in and regulates the struggle by making a thinning. While doing this he cuts and removes for sale the trees which are falling behind, and at the same time relieves the best trees of all excess of pressure, giving them just enough light and root space, thus reducing without stopping the struggle for existence. After a thinning has been made, the remaining trees soon close up and the struggle again commences, another thinning being necessary in a few years' time. This continues as long as the trees grow vigorously.

The advantages of thinning are, put shortly, as follows :-

I. They enable the woodman to guide the development of the wood, and to give the proper growing space to the best trees which will form the final crop.

2. In mixed woods the woodman can favour certain species, cutting others out gradually, so as to get the mixture he requires.

3. By the removal of dead, dying, and unhealthy trees, danger from insects, fungi, and fire is greatly reduced.

4. The trees which are to form the final crop are gradually strengthened against damage by wind.

5. They give, under favourable conditions, early and substantial money returns.

In any wood which is at all dense we can recognize four classes of trees. We find certain trees with their heads right out to the light and above all the surrounding trees; they are 
the tallest and best in the wood, and will probably form the final crop. Such trees are called dominant or dominating trees. Among these we find trees which are beginning to fall behind in the struggle for existence; their heads are still well up to the light, but they are partly shaded by the dominant trees, and they will obviously be gradually left behind. These are the dominated trees. Below the dominant and dominated trees we find others completely left behind. If left alone they will gradually die; these are the suppressed trees. Finally we find dead trees.

Now one of the chief objects of a properly conducted thinning is to give the proper growing space to the best trees which are to form the final crop, and therefore it follows that the trees to be cut must be those which are pressing too much on these dominating trees, and which are depriving them of the necessary light and root space. In all thinnings dead trees should be cut out, as these might prove breeding grounds for insects and fungi. In pure woods, suppressed trees should also usually be removed, as they are unhealthy, but they may be left if they are only partially suppressed, and are doing useful work by increasing the cover, or by shading the boles of well-shaped trees, and if they are of a species not specially liable to attack by insects and fungi.

With regard to the dominated trees it is usually best, in most cases, to leave them standing to cover the soil, but if they are so numerous that they interfere with each other's development, some of these may be cut out. The best rule to follow is to thin amongst these in such a way as to form no large break in the leaf-canopy, so that when the thinning is finished there is still a complete cover over the ground. Any dominated tree which is damaging or over-crowding a dominant tree should be cut.

The dominant trees are left standing, except that a badlyshaped, unhealthy, or very large crowned one should be cut out if this will enable a well-shaped dominated tree to take its 
place; and also, when three or four dominant trees are struggling against each other, the best tree should be relieved by cutting one or more of the others.

In mixed woods matters are rather different, as it is often advisable to cut out a dominant tree of an inferior species for the sake of a dominated one of a more valuable species; thus a birch would be cut out if topping an oak. Moreover, in such woods care must be taken not to cut a shade-bearing species merely because it is under a light-demanding one. Such a tree is not necessarily suppressed, and is doing useful work in covering the soil. All light-demanders suppressed beyond recovery should be cut out, but shade-bearers should only be cut if they are suppressed by a taller shade-bearer. If a valuable light-demander is beneath an inferior one, the latter should be cut if the former is likely to recover.

In a mixed wood it is also necessary to consider the peculiar character of each species, and to carry out the thinning accordingly. Thus in a mixed beech and oak wood, while the beech should be kept close-grown the crowns of the oak must be more thoroughly freed.

In order to produce the highest quality of timber, thinnings should be commenced early, repeated frequently, and moderately. This is the golden rule for thinning.

The best procedure is to make the first thinning at about the fifteenth year for light-demanders, and at about the twentieth year for shade-bearers, when the struggle for existence has been properly set up, when a few dead trees are found here and there, and when the lower branches have been killed. The thinnings should then be repeated every five years for light-demanders, and every ten years for shadebearers, and be light in character till the woods are fifty or sixty years old. Conifer woods do not generally require thinning after this age except to remove dead or unhealthy trees, as they are usually felled at from seventy to eighty years of age; but with broad-leaved species, if these are to 
be left to grow into large timber, the thinnings are now made more heavily, so as to gradually isolate the crowns of a selected number of the best trees. At this time the thinning takes place chiefly among the dominating trees themselves, the dominated and partially suppressed trees being left to cover the soil; in addition the woods may be underplanted if the crop consists of light-demanding species.

The trees to be cut out in a thinning should be carefully marked while the leaf is still on them, as the effect of the removal of a tree can then be more easily estimated; they are cut in winter. A good rule for the marker is not to mark any tree unless he can put into words a reason why the tree should be cut. If it is doubtful whether a particular tree should be cut or not, it is better to leave it, as it can always be cut out later on, while if it is once cut it cannot be put back again! It is also best to mark lightly at first, as some of the trees to be left may be damaged in carrying out the thinning, and it is well to have others to take their place. After the cutting has been made, the area can be gone over again to remove any tree which it is then seen should come out. Care must be taken not to mark a tree simply because it is of bad shape, as such a tree may be doing useful work in clearing the branches off a better tree, and is helping to form cover over the ground. Badly-shaped trees, which are otherwise doing good at present, will be removed in the later thinnings.

By keeping woods fairly dense while they are rapidly growing in height we cause the trees to become tall, straight, and free from branches, while by making the thinnings heavier towards the end of the principal height-growth we let in light to the crowns, which then enlarge, and, owing to the increased foliage, more food material is formed and the stems increase rapidly in girth. If we keep the woods too open to start with we get a small number per acre of short thick trees, while if they are kept too dense we get a large number of tall, lanky trees. The proper state is to keep between the two 
extremes, inclining to density in youth and openness towards maturity.

No regard should be paid to the distance apart of the stems. It is at the crown that the woodman looks when making a thinning, and so long as the crowns are kept so close that there is a complete cover over the ground at all ages, it matters not whether the stems are regularly or irregularly spaced. The following figures given in Schlich's Manual of Forestry, volume I, third edition, act as a guide as to what number of stems may stand on an acre at various ages on average soils if the production of high-class timber is aimed at, and if the woods have been well managed from the start, but these numbers are far in excess of what will usually be found in existing British woods, owing to over-thinning in the past. On first-class soils the number of trees will be smaller, and on poor soils larger.

\section{Number of trees per acre.}

Age of Wood. Spruce. Beech. Oak. Scotch pine and Larch.

$\begin{array}{rrrrr}40 & 1100 & 950 & 850 & 750 \\ 50 & 700 & 600 & 550 & 500 \\ 60 & 500 & 420 & 370 & 400 \\ 70 & 400 & 320 & 270 & 300 \\ 80 & 300 & 250 & 220 & 250 \\ 90 & 260 & 200 & 180 & 200 \\ 100 & 220 & 180 & 140 & 170 \\ 110 & 200 & 170 & 120 & 150 \\ 120 & 190 & 160 & 100 & 140\end{array}$

As a general rule conifers can stand closer than broadleaved trees, and shade-bearers than light-demanders. Species like oak and Scotch pine, which tend to the formation of side branches, should be kept closer when young than species without this tendency.

A thinning is called light when only dead and suppressed trees are cut out; moderate when some dominated trees are also cut; heavy when some of the dominating trees are removed. 
Sometimes, especially in woods at present from thirty to fifty years old, where oak has been grown with larch nurses, it is necessary to cut out all the larch, which are often of large size, for the sake of the oak. In such an operation a very large proportion of the volume of the standing crop is removed. After the cutting has been made the woods are usually very open and have to be underplanted. Such a cutting is no longer a thinning in the correct sense of the word, but is a partial clearance of the crop.

Unfortunately the method of thinning practised in most British woods up to a recent date has been incorrect, and the result is that nearly all existing woods have been very largely over-thinned. This has resulted in the standing crop being of far less value than it should have been; the trees, being far apart, have large branching crowns and short stems. There has been too much rule-of-thumb about the method. An ordinary rule was to thin the trees till they stood at onethird of their height apart. This means that a larch wood sixty feet high would contain only Io9 trees per acre, instead of about 400, while the shade-bearing Douglas fir would be given the same, or possibly more, space than the lightdemanding larch, which is not only unnecessary, but causes the formation of very knotty timber. Again, very often when timber was required for estate purposes, or to fetch in an increased revenue, the tallest and best trees were cut, leaving the dominated and suppressed trees to form the crop. This is a ruinous procedure, as trees once suppressed very seldom recover, and the final crop consists of poor badly-grown trees.

It is largely owing to this over-thinning and early removal of the best trees that many of our woods are in such a poor state, and that foreign timber is preferred to British. If the owner requires an extra revenue, it is far better to clear cut an area large enough to bring in the required amount, than to over-thin the whole wood.

Thinning is the most important operation carried out in 
pole woods, as upon the way it is performed depends the future development of the woods; the marking of the trees should not therefore be left to a woodcutter, but it should be done by the head forester or woodman himself. In felling, every precaution must be taken not to injure the standing crop; tall trees should be lopped and topped if they are likely to do damage in falling.

Short, small-girthed trees can often be saved from damage from falling timber by pulling their crowns partly to one side with a rope or with a long hooked pole. When the logs are being dragged out of the area, a stake should be held between the $\log$ and the butt of any tree which is likely to get rubbed.

Woodcutters engaged in thinning dense crops should be paid by the day, and not by piece-work, as otherwise they may not take sufficient care.

\section{PRUNING}

Pruning is an expensive operation, and it should never become necessary if woods are grown sufficiently dense from the beginning. When this is done, the side branches get killed off by the heavy shade before they get of any size, they drop off, and the timber formed is clean. If, however, woods have been grown in a too open manner, the trees will probably bear a considerable number of branches below the proper crown, which will reduce the value of the timber, and it may be desirable to prune them if the species is of sufficient value to warrant the expense.

A dead branch can be of no benefit to the tree, while, if it is allowed to remain, it will gradually rot, and this rot will travel down the branch into the stem, and will probably spoil a considerable length of timber below the branch. Moreover, even if it does not rot, the branch will be gradually enclosed in the stem, as it grows in girth, and will cause a hard knot lying loose in the timber. A dead branch may therefore 


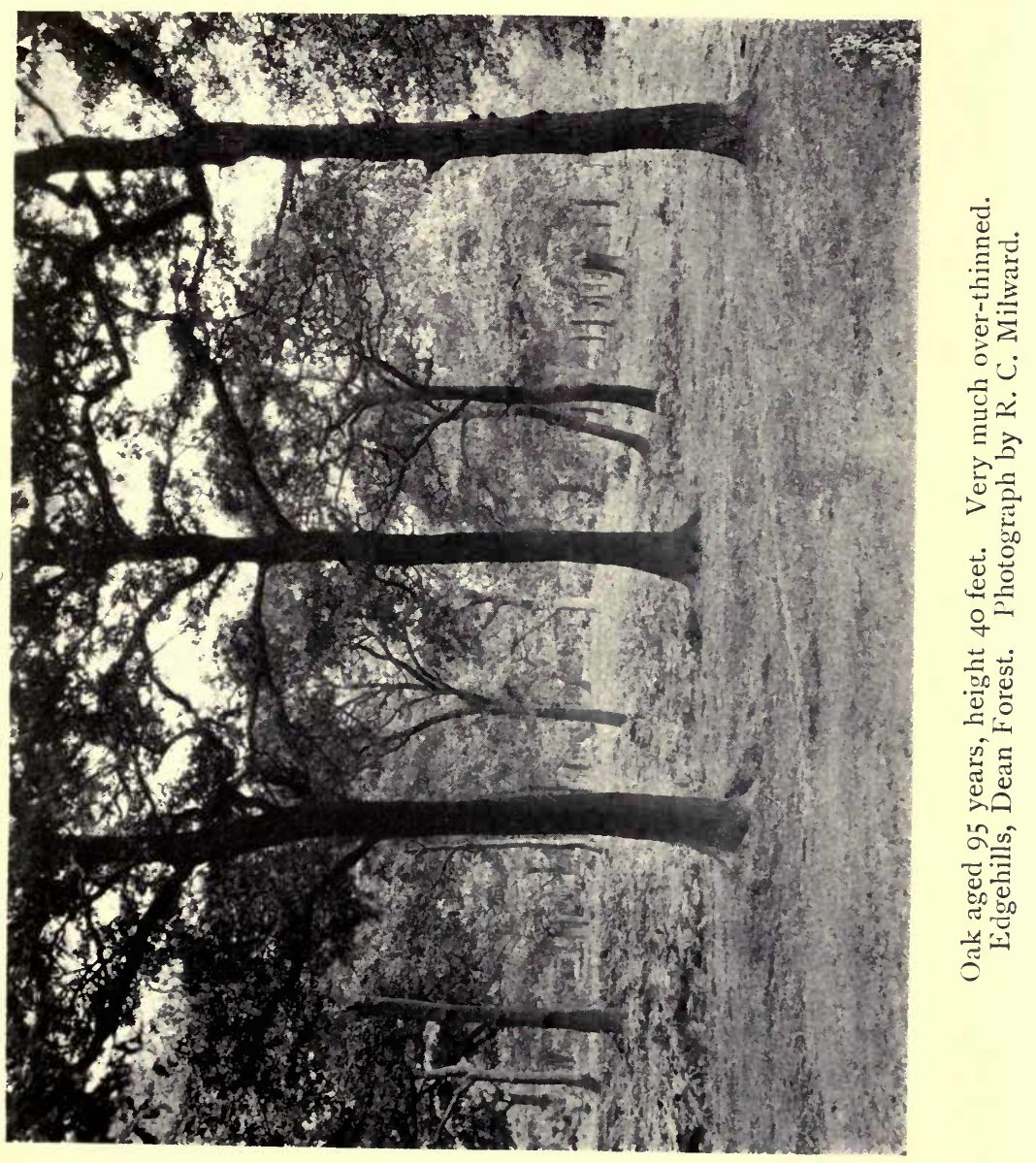



always be cut off at any time of the year, and its removal will decidedly benefit the future value of the tree. Pruning of dead branches should be carried out while the trees are young, not later than about twenty to twenty-five years of age. A saw is usually the best instrument to use, and the branch should be cut off as close to the stem as possible; the cambium then gradually forms a layer of wood and bark over the cut surface, and if the wound is a small one the process, which is called occlusion, is completed in three or four years' time. Dead branches of larch are best knocked off with the back of an axe; this is an easy operation, and there is less risk of damaging the bark of the stem than when the cutting edge is used.

The removal of a green branch is a more serious operation, as this reduces the area of foliage; the wound made is, moreover, a fresh one, and exposes living tissues upon which the spores of fungi may settle, thus introducing rot. As a general rule therefore, it is not advisable to prune green branches unless they are so small that the wound made will be occluded rapidly; generally no green branch should be pruned if larger than two inches in diameter. The knot made by a green branch is not so bad as one from a dead branch, as the fibres are in connexion with those of the stem, and thus the knot is never a loose one liable to drop out of a board as does that of a dead branch. Oak will stand pruning well, while conifers can also be fairly safely pruned, as turpentine exudes and protects the cut surface. It is, however, very seldom worth while to prune green branches off conifers, on any large scale, as if the woods are so open that pruning is necessary the value of the timber will, in any case, be small, and the amount spent on pruning will probably not be repaid by increased value.

Large green branches should never be pruned except for a special reason. There is always a flaw at the place operated upon, and the removal of a large branch very seldom improves 
the value, as timber merchants rightly look with suspicion upon marks which show that pruning has taken place. Such a branch should only be removed when it is necessary to give light to an under crop of young trees, and when the removal of the whole tree is impossible or undesirable.

Green branches should be cut off as close to the stem as possible, and in such a way as to leave a smooth surface, as this resists rot better than a rough one. The work can be done with knife, hatchet, bill-hook or saw, and it is usually best to allow the workman to use the tool he prefers. Heavy branches should first be cut off two feet from the stem to reduce the weight, and to prevent any possibility of tearing or splitting the stem, and, in all cases, the work should begin with a cut on the lower side, for the same reason.

When large branches are removed on ride sides or in parks, the wound should be painted over with coal-tar, made sufficiently fluid by the addition of oil of turpentine, to prevent rot or disease.

As a general rule in forestry, pruning on a large scale should be restricted to the removal of dead branches in young woods of oak, larch, and pine. 


\section{CHAPTER VII}

\section{METHODS OF TREATMENT}

WHERE the woods are extensive it should be one of the chief objects of the woodman to manage them in such a way as to get a sustained and regular annual yield. All haphazard working must be put an end to, and an endeavour should be made to cut only that amount of timber which the forest is capable of producing annually. The owner then knows that his woods are not being overcut, and has the satisfaction of being able to depend upon a more or less steady income from them instead of receiving perhaps a large income one year and very little in the next.

Before putting into force a regular treatment the woodman must decide as nearly as possible the age at which the woods will give the most paying size of timber, or, in other words, he must fix the rotation or the period in which the whole of the woods shall be cut over once. He must also decide which of the main sylvicultural systems, or methods of treatment, will suit his purpose best. There are three main systems, called high forest, coppice, and coppice-reith-standards or copse.

A wood is called high forest when it consists solely of seedling trees, that is, of trees which have grown up from seed sown artificially or naturally on the spot, or of plants raised from seeds sown in a nursery ; the term is, however, sometimes applied to a wood in which the trees are coppice shoots, though only one shoot has been allowed to remain on the stool to grow into a tree.

All species can be grown in high forest, and produce of any desired size can be obtained from such woods by fixing the rotation according to the size required. 
Coppice is a wood consisting of shoots which have sprung up from the stools of felled trees. From such a wood only small produce is usually obtained, and broad-leaved trees alone can be treated under this system. Coppice-zith-standards, copse, or stored coppice is a wood which consists partly of seedling trees which usually form an overwood, and partly of coppice shoots which usually form an underwood. From such a wood both large and small produce is obtained, but the timber is not usually so tall, straight, or clean as that obtained from high forest.

With regard to the rotation it is impossible to say, when planting woods, at what age they will be exactly fit for the axe, but we may assume that this will be approximately the age at which we now find existing crops to be mature.

At present the following rotations are about the most profitable :-

High Forest.
Oak
120 to 150 years.
Beech
100 to $\mathrm{I} 20$ years in most places.
80 to 90 years in some places.

Ash, maple, sycamore, elm, and chestnut, 60 to 90 years. Conifers

60 to 80 years.

Coppice.

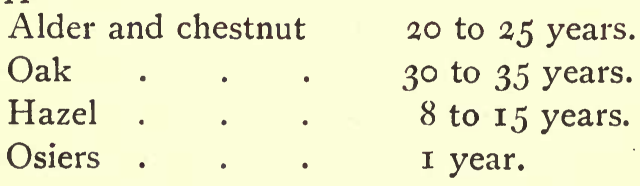

The length of the rotation depends greatly on the local demand; when, for instance, conifers can be sold as pit-wood, a rotation of forty years can be adopted, while where small stuff cannot be sold the rotation must be sixty or seventy years at least.

In coppices where fuel cannot be sold it is usually best to have as long a rotation as possible up to the age beyond 
which the stools will not give healthy shoots. In the Highmeadow woods belonging to the Crown the rotation for mixed coppice of beech, oak, and chestnut is now fixed at thirty-five years, as at this age a large proportion of pit-wood is obtained, while fuel is practically unsaleable in the neighbourhood. As a general rule, under all systems with long rotations the fertility of the soil is well maintained and the timber produced is of first-class quality, but, on the other hand, the owner's capital is locked up for a considerable period, during which he gets but a small return. With short rotations the soil is exposed frequently and may deteriorate, the timber obtained is soft, as it mostly consists of sap-wood, and it is usually short in length. If the produce is readily saleable, however, the owner does not have to wait so long for his returns.

\section{High forest system.}

Where high forest has been decided upon, the cutting of the existing crop and formation of the new crop may be carried out under either of the following methods of treatment :-

I. Clear cutting.

2. Successive regeneration fellings, or Compartment method.

3. Group method.

4. Selection method.

\section{The Clear cutting method.}

Cuttings should be so carried out that at the end of the first rotation there will be upon the ground a series of approximately equal areas of even aged woods, varying in age from one year up to the number of years in the rotation. The total area of the woods is divided by the rotation, and this gives the area to be cut annually. Thus if there are $6 \mathrm{co}$ acres of wood, and the rotation is fixed at sixty years, an area of 10 acres is cut over each year and is at once planted 
up. At the end of the first rotation there will be upon the ground :-

Io acres covered with wood 60 years old.

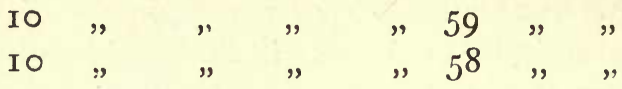

and so on to

IO acres covered with wood 2 years old.

I0 " " " I year "

the age here meaning the number of years since the plantation was formed. After the first rotation the owner, in theory, will be able to cut ten acres of mature wood for ever, assuming that the fertility of the soil is maintained. If the present crop is even aged, the crop cut at the end of the first rotation will of course be older than that cut at the beginning. The value of all the crops (with the exception of the mature wood on Io acres) together with the value of the land, represents the capital invested, while the value of the ten acres of mature trees plus the value of thinnings in the younger woods minus the annual expenses, represents the interest the owner receives.

In practice there is no reason why the falls should follow each other regularly over the area, in fact for reasons given in Chapter VIII it is better that this should not be the case. The oldest crops should generally be dealt with first, together with those which are growing badly, but the protective measures against insects, fungi, and storms mentioned in Chapters VIII, IX, and X must also be taken into consideration in locating the order of cutting. The theoretically correct area need not be invariably cut every year and under all conditions ; where, for instance, the soil and growing crop is poor, a larger area may be cut than where it is good, to equalize the yield.

The area decided upon for the year's working is clean cut, leaving nothing whatever standing upon the ground; a new 
crop is then formed as soon as possible by sowing or planting, and this is tended on to maturity with the necessary thinnings, and is then again clean cut. The crop in any block is even aged, and as, after the thicket stage, the sunlight only reaches the tops of the crowns the trees grow tall, have clean boles, and produce fine timber. At any felling the produce obtained is all of about the same size, and as it is all lying together it is usually readily saleable. The method is a simple one, and easy to carry out. No damage is done to young growth in the fellings; on the other hand, as the young crop is formed on cleared ground there is considerable danger of damage by frost and drought, while weeds are also troublesome, and the ground being exposed for some years the soil may deteriorate. As compared with methods where natural regeneration is possible, the formation of the new crop is expensive.

All species can be treated under this method, but it is chiefly suitable for hardy soil-improving species, such as spruce and Douglas fir, and for the pines on short rotations. Where light-demanders like oak, ash, and larch are grown under this method they must be mixed with soil-improving trees, or a modification of the method called Two-storied high forest must be employed. This consists of first planting the lightdemanders, and when these are thirty to forty years old under-planting them with shade-bearers. The two crops grow on together and the whole is then clear cut when the light-demanders have reached the desired age.

On the whole, when the soil is of good quality, and where the conditions are unfavourable for natural regeneration, this is a suitable system for many woods. Where, however, the existing woods act beneficially in a mechanical way such as by holding up the soil on steep slopes, or when they are situated in exposed positions where it would be difficult to form a new crop, or where they are required for shelter, clear cutting should not be employed. 


\section{The method of successive regeneration fellings, or the Compartment method.}

In order to decrease the damage done to young crops by insects, weeds, frost, and drought, the new crop can be formed under the shelter of the old crop, or of part of it, instead of on a large blank area. The shelter given by the old trees then protects the young plants and also prevents to a considerable extent the deterioration of the soil by exposure. The new crop can be formed by sowing or planting or by natural regeneration from seed falling from the shelter trees, which in this case are called the Mother trees. When conditions are favourable, as much as possible should be done by natural regeneration; planting should be undertaken only when the former fails.

Where the new crop is formed by sowing or planting, the size of the annual cut is found, as in clear cutting, by dividing the total area by the number of years in the rotation. This area is then cut over each year, but, instead of making a clean cut, a certain number of trees are left standing. These should be evenly scattered over the area and should be trees of which the crowns are small and without branches low down on the stem. The number left depends on the species to be planted. If this is a tender shade-bearing species such as beech the cover left should be fairly heavy, while if it is a light-demanding and hardy species such as oak the cover should be light. The young trees are planted under this shelter wood, and when they are well established the shelter trees are removed. After this has been done, the future management is like that under the clear cutting method. With a little care the shelter wood can be removed without doing any great harm to the young crop, and the increased value of the shelter trees, which put on girth rapidly, will usually make up for the damage done.

Where the existing crop contains coppice, a very efficient shelter can be got by leaving tall coppice shoots evenly scat- 
tered over the area. These can be removed three to five years after the young crop has been planted, and can be easily carried away by men, or can be left on the ground if they are not saleable.

The method is, however, chiefly used when the new crop is to be formed by natural regeneration. In this case a number of annual cutting areas should be dealt with together, as it is impossible to work with the same regularity as when the crop is planted, owing to the irregularity of seed years. If, for instance, it is found that ten years is the usual period for completing the regeneration from start to finish, ten times the average cutting area should be dealt with at one and the same time; when this has been successfully regenerated, another block is taken in hand.

With natural regeneration an equal annual outturn can seldom be obtained, but this inconvenience is, to a certain extent, counterbalanced by the low cost of the new crop.

By natural regeneration we mean the production of a new crop by seed thrown from trees already on the ground. As the new crop becomes established the existing trees are gradually removed, so that the old wood, in the course of a few years, is cut down and replaced by a new one. It is by natural regeneration that a wood untouched by man gets reproduced; when a tree dies, from old age or other cause, an opening is formed in the cover and seed falling from surrounding trees germinates and springs up. In nature this process is a slow one, but in sylviculture it is hastened by the removal of mature trees and by aiding the young crop.

British foresters mainly rely on planting, but there is no reason why under favourable conditions, where rabbits are kept down and where weeds are not luxurious, natural regeneration should not often be carried out for the reproduction of beech, oak, ash, birch, sycamore, and Scotch pine.

Natural regeneration is usually cheaper than planting, and under very favourable conditions the cost may be practically 
nothing. Where, however, weeds are very luxurious the cost of cutting them away may amount to more than the cost of planting with large plants.

The young crop is greatly protected from frost and drought by the shelter trees, and weed growth is also reduced, while another advantage is that a very large number of plants are obtained on an acre, and consequently, with good after management, cleaner and straighter stems are produced. On the other hand the operation is more complicated than planting and requires more highly-skilled woodmen; other disadvantages are that the removal of felled timber is more difficult and expensive, and that it is not easy, owing to the irregularity of good seed years, to arrange for an equal annual yield of timber, cuttings being heavier in some years than in others.

To describe how natural regeneration is carried out, the general theory will first be explained, and then such modifications as are usually necessary in British woods will be alluded to.

\section{The Theory of natural regeneration.}

Let it be assumed that a very dense beech wood about eighty years old is to be cut and regenerated. In such a wood it will be found that there is overhead a very dark cover, and that the individual trees are tall stemmed and have small crowns; it will also be found that they do not bear much fertile seed. Below, the surface of the ground will be covered with a thick layer of dead leaves and partly decomposed humus, which is not a favourable germinating bed, as the mineral soil is too far from the surface. Under such a wood very few seedlings will, in fact, be found. The first object of the woodman is therefore to get the wood into a fit state for regeneration by inducing the mature trees to produce fertile seed, and, by causing the dead leaves to decompose quickly, to get the soil into a proper condition to receive it. He does 
this by making one, two, or more preparatory cuttings or heavy thinnings. By doing this, air, light, and rain are let into the wood; the crowns of the trees left standing soon grow larger and bear better seed; and the humus decomposes more rapidly. This preparatory stage may take ten or fifteen years. Before starting these cuttings the future shelter trees should be marked evenly over the area and the thinnings should be then made so as to open these out gradually, starting operations by cutting out any undesirable species which may be standing in the wood, all very badly shaped or diseased and overmature trees. Those with well developed crowns should be left as future mother trees. In the course of time the conditions will be nearly ready for regeneration, and mineral soil will be seen here and there on kicking up the humus with the foot. Operations now cease till a good mast year arrives. Pigs may be admitted to the woods till the seed begins to fall, as they grub up the soil and improve the germinating bed. When the mother trees are seen to be covered with a good crop of seed another cutting is made called a seeding cutting. This has for its object the removal of all trees not wanted as future shelter to the young crop. It may be made when the seed is quite ripe, and probably the best period is just as the seed begins to fall naturally from the trees. The seed on the felled trees is then well scattered over the area during felling operations. Care must be taken to leave the proper number of trees to form an efficient shelter. Rather a dark shelter is required for beech, as the seedlings are frost-tender and shadebearing. On soils where weeds grow rapidly or where the woods are exposed to strong winds or on poor loose stony soils, the shelter wood should be kept darker than under opposite conditions.

All trees not required for future shelter are cut down, usually about one third to one half of the crop on the ground being now removed. The felled trees must be at once taken out of the area, and this work must be completed before the 
seedlings germinate in spring. The dragging out of the timber will bury a considerable quantity of the seed, but if thought desirable a harrow may be dragged over the ground to make matters more sure; the admission of cattle at this stage is advantageous, as they tread in the seed. If the operations have been well carried out, a thick crop of seedlings will shortly appear, and the final work is to remove the shelter wood. This is done by one or more final cuttings, during which the shelter wood is gradually cut down at such intervals as appears necessary for the benefit of the young crop. As long as this looks healthy and is growing well, the shelter trees may be allowed to stand as they rapidly increase in girth and value owing to their isolated position.

Usually with beech a cutting is made when the seedlings are two years old, and this is repeated at intervals of three or four years till the young crop is completely uncovered; matters may be hastened when there is little or no danger from frost or weeds. Under favourable circumstances the final stage is completed in six to eight years, while occasionally it may take as long as fifteen.

When the last of the shelter trees have been removed, any blanks in the young crop are filled up by transplanting trees from patches where the regeneration has been successful, or by introducing another species. In fact this is a good opportunity to plant larch, oak, ash, and other species into the beech wood to form a mixture.

It would appear at first sight that the removal of the shelter wood must do considerable damage to the young crop. This, however, is not the case if the fellings are carried out with reasonable care. There are usually a very large number of seedlings on the ground, and a considerable proportion of these may be destroyed in the final operations without endangering the success of the regeneration. What appears to be great damage while the plants are two or three years old will not be noticeable after a few years when the surrounding 
Plate VI

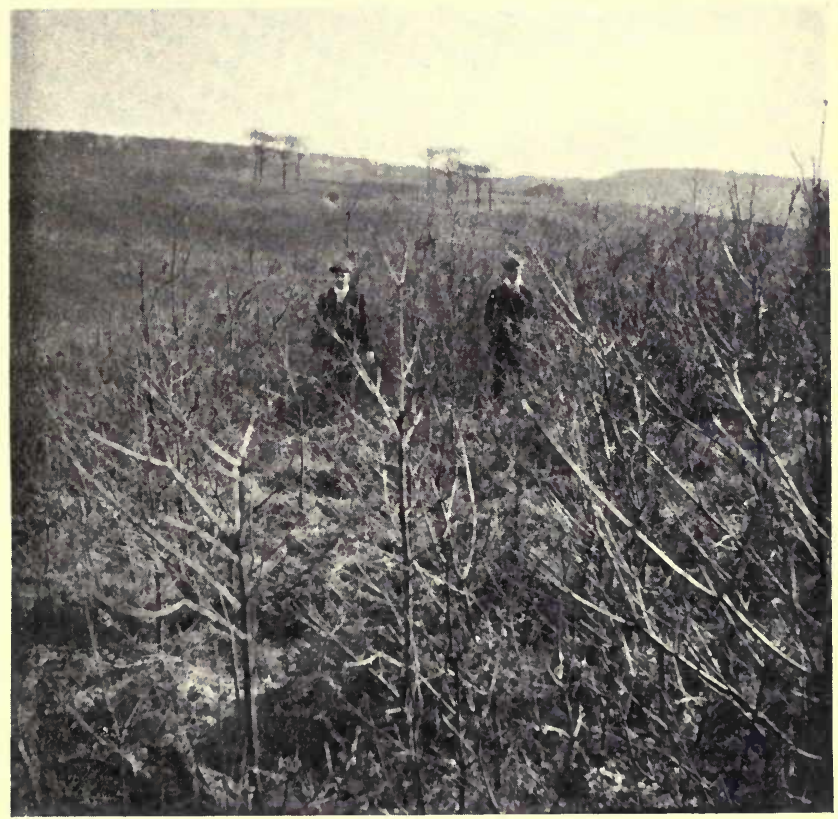

Natural regeneration of oak aged about 8 years. Blakeney Hill, Dean Forest. 

plants have grown taller. Nevertheless care must of course be taken; the larger trees should be removed in the earlier cuttings, as they can then be got out with the least damage; trees must be lopped if they are large crowned, and they must be felled in the direction where least damage will be done. They should be removed on timber-carts and should not be dragged out of the area.

\section{Modifications in practice.}

In British woods it is very seldom necessary to carry out any preparatory cuttings whatever, as they are usually already open enough, and there is seldom an excess of humus. It is unfortunately more often the case that the soil is covered with a mass of weeds or with a hard turf. In these cases the preparatory stage consists of cutting the weeds and working up the soil just before making the seeding felling. A light forest plough may be run over the ground, or the soil may be hoed up in strips about two feet wide and four feet apart. The seeding felling being completed, the seed may be raked into these strips and be lightly covered.

In British beech woods no preparatory cuttings are usually required. When a good mast year comes all except about 50 trees per acre are cut in the seeding cut. When the seedlings are two years old a final cut, removing about half the crop, should be made, and the rest should be removed in a few years' time.

With oak about 40 trees per acre should be left as a shelter wood, all others being cut away in the seed felling. As soon as the seedlings are three years old, the whole of the shelter wood should be removed, as the young plants are lightdemanders and do not suffer from frost. An area of about 370 acres of oak wood in the Forest of Dean was, during the years 19c0-1904, most successfully regenerated, and there is now a dense young crop of seedlings on the ground of all heights up to $I 2$ feet, the average being about 5 feet; 40 
plants have been counted on an area of 5 feet by 5 feet. The area was by no means an exceptionally favourable one, as the ground became covered with a thick growth of bracken as soon as the wood was enclosed; this was cut annually till the young oak was safe : rabbits, however, did not exist.

With ash, sycamore, and birch, I5 to 20 mother trees per acre are all that is usually necessary, as the seeds are winged and travel to a distance. If, however, the area is exposed to frost a heavier cover is necessary with ash, and, as the seedlings are distinctly shade-enduring during the first few years, this can easily be given. Provided sufficient mother trees are present, and that rabbits are absent, regeneration is very easy with these species and it is usually only necessary to keep down weeds. No soil preparation is necessary. The shelter wood should be removed in three or four years. As with the oak, a considerable area of ash has been very successfully regenerated in the Highmeadow woods near Dean Forest. The young crop is now nine years old, is very dense, and in some places is $\mathrm{I} 2$ to I 5 feet high, the only work done having been the cutting back of brambles and coppice shoots, and the extermination of rabbits, which were fairly plentiful at the commencement of operations.

With Scotch pine, the young crop being hardy and very light-demanding, no shelter is required; the mother trees should therefore stand far apart, about I 5 to 20 trees being sufficient on an acre. These should be removed as soon as seedlings in sufficient quantity have appeared over the greater part of the ground, blanks being filled up by planting. Where there is danger of the mother trees being blown down they may be left in clumps over the area instead of leaving a single tree here and there. Some soil preparation is necessary if there is a thick layer of needles on the ground. Pine seedlings will come up well through heather, if not very thick, so this need not be cut away; in fact heather land is just the place where regeneration will prove most successful. 
In British woods, where weeds usually abound, it is seldom desirable to await a second seed year if the regeneration fails at the first. It is usually better to plant up the area as soon as it is certain that the regeneration has failed. When there is a very good mast of oak or other light-demanders, it is often possible to cut all the trees at the seeding cut, leaving no shelter.

When considering the desirability of naturally regenerating woods it is important to take into consideration the age of the existing trees.

The different species begin to produce good seed at the following ages :-

Birch, white alder, acacia, aspen at 25 to 30 years.

Pines, larch, Norway maple, alder, lime at 30 to 40 years.

Hornbeam, wych-elm, ash, sycamore at 40 to 50 years.

Spruce at 50 to 60 years.

Beech at 60 to 70 years.

Oak, silver fir at 70 to 80 years.

\section{Group method.}

Wherever it is not desirable to have large clearings this method is a good one. Throughout the forest, groups of moderate size and of any shape are cut and are regenerated. In succeeding years other groups are taken in hand, and those first formed are enlarged periodically till in the course of time all merge into one another. The forest is thus continually changing in character, and is uneven aged, patches of all ages and sizes being found. The groups first attacked should be those where the trees are mature or are growing badly; and wherever patches of natural regeneration are found on the ground the old trees are removed from over them. The new crop can often be obtained by natural regeneration, more especially with shade-bearing species like beech, silver fir, and spruce, but regeneration of oak, ash, and other light-demanders can also be got by making the groups fairly large, so that 
sufficient light is given to the young crops ; in fact the method is essentially one for natural regeneration.

In order to obtain a fairly equal annual yield, about the same area should be cut over each year; thus if the total area divided by the rotation comes to ten, about ten acres should be cut annually, in scattered groups. It is usual, however, to fix the volume of timber which may be cut, and not the area, but this must be done by an expert. The groups may be clear cut if there is natural regeneration already on the ground, or if the new crop is to be formed by planting, or if the cleared patches are not larger than twenty to twenty-five yards in diameter and there are seed-bearing trees on the edges, of species whose seeds travel some distance. Where the patches cleared are larger than this, some mother trees must be left to seed up the area. Trees should always be felled outwards into the untouched area, and with care the timber can be taken out without having to pass through young crops. Where there are plenty of rides through the forest each group may be so formed that it touches a ride, and it may take the form of a strip. This method is very suitable for the natural regeneration of mixed woods. Thus where a few ash are found it is easy to cut away all other species, ensuring the regeneration of ash only in that group. In another place oak may be left, in a third beech, and so on. It is also an excellent method for the regeneration of beech woods. The soil is very well preserved and the new crop is well protected against frost, drought, and weeds, and there is never any large area uncovered. Insects and fungi do less damage in woods managed under this method than under those already described. The woods remain very wild looking, and are beautiful, as there is no formal arrangement of the crop, and trees of all sizes are found mixed together in groups as they are in natural woods. Such woods are also good pheasant preserves.

The whole area should be worked over once in the rotation. 
At the end of that time there will be found groups of trees of all ages from one up to the number of years in the rotation, irregularly scattered over the area.

An objection to the group method is that the woods get little rest, as work is going on more or less over the whole area. On the other hand it is easier to obtain an equal annual yield than under the last method, because it is not difficult to find groups where some cutting is necessary. To avoid disturbance of the whole area every year, the woods may be divided into four or five blocks. One block may then be worked in, year after year, till it is regenerated and then another block may be taken in hand.

\section{The Selection Method.}

Under this method the forest is theoretically worked over throughout its full extent every year, taking out single trees or small groups of three or four trees here and there, always cutting all trees which are dying, diseased, or mature wherever they are found, and making necessary thinnings wherever the crop is too thick. It is like the group method, where the group is reduced to the space left by removing only one or two trees. In practice, in order to localize the fellings, it is usual to divide the forest into from seven to twelve equal blocks and to work in a different block each year. The forest is entirely uneven aged, trees of all ages and sizes being found mixed up together. As no blanks are made, the method is only really suitable for shade-bearing species such as beech, and the new crop is usually formed by natural regeneration. The method approaches what is found in natural woods untouched by man. Wherever a little light is let in seedlings appear; these usually grow slowly under the heavy shade, but they may be assisted, by removing trees which overshadow them, in the future cuttings. Unfortunately brambles also appear in the openings, and this adds to the difficulties. The beech woods in Buckinghamshire are mostly managed under 
this method, but it would probably prove more advantageous to work them under the group method, as the young trees would grow more rapidly.

There is great danger of overcutting where woods are worked under this method, as it is very difficult to calculate the number of cubic feet which should be cut, and there is no area check. Hence, unless the woodman is very skilful, a time may come when no trees of mature size will be found standing in the wood. Where, however, there is a working plan prepared by an expert the volume of timber which may be cut annually is laid down.

The soil is excellently preserved, while damage by frost or drought is reduced to a minimum; on the other hand, the trees grow slowly, and the carrying out of the fellings is expensive and difficult, as more damage is done in felling in woods where the trees are of varying heights than where all trees are of more or less the same height. The trees are often crooked when grown under this method, as each tree, as it were, feels round and grows towards a hole in the canopy. The method is only suitable in those places where it is essential to keep a continuous shelter over the ground, e.g. on steep slopes and exposed hill-tops. It can also be used in very small woods which are not large enough for an equal area to be cut each year. All woods which are left out of the general scheme, such as those round the owner's mansion, or those worked solely with an idea to beauty and not for revenue, may be managed under this method.

\section{Coppice System.}

All broad-leaved trees can be coppiced, the reproductive power of oak, sweet chestnut, sycamore, alder, hazel, and ash being, however, greater than that of birch, beech, sallow, and aspen. When a young wood of the above species is cut down a number of shoots arise from the stools, and, growing rapidly, soon form a dense thicket; this is allowed to grow to the size 
desired, and is then cut down to reproduce itself. To obtain strong shoots the cut should be made as near the ground as possible, as the new shoot then often forms roots of its own, and becomes independent of the old stool. The only exception to this is where floods are likely, as in alder coppices; here the stools may be cut a foot from the ground. 'The cut should be smooth, and slanting, so that water cannot lodge on it, and the bark must not be separated from the wood. The best season for cutting coppice is February and March, as if it is done in autumn frost may separate the bark. As few species have the power of sending out good shoots from stools over forty years of age, only small produce can be obtained from coppice woods. Formerly oak was largely grown on a rotation of from eight to sixteen years for bark; alder and other species were coppiced for charcoal for the manufacture of gunpowder; chestnut for hop-poles, and ash for various purposes, but at the present time, owing to the fall in prices, it will seldom pay to grow any of these as coppice, as small produce can now seldom be sold.

There is, however, a considerable area of osier holts, or coppices of various species of willow, used for basket-making, in Great Britain, and this industry might be extended on deep, rich, alluvial land liable to be flooded occasionally. Salix viminalis, triandra, and purpurea are the chief willows employed. To form an osier holt the land is thoroughly cleaned the summer before planting, and is ploughed or dug to a depth of 14 to 16 inches. The willows are planted in February or March, using sets or cuttings from wood of two years' growth, 16 inches long, of which 10 inches are put in the ground. The shoots are cut back annually, and the holt usually lasts about fifteen years before the stock must be replaced. For further details regarding this work the woodman should obtain the Board of Agriculture leaflet No. $3^{6}$.

For coppices of other species the age of the produce most easily sold should be ascertained, and this should be taken as 
the rotation. The amount to be cut annually will then be the total area divided by this rotation. It is, however, very seldom the woodman will now be called on to manage a simple coppice, he is more likely to have to convert existing coppices into high forest. In any case new coppices should not be formed unless the future market for the produce is assured.

\section{Coppice-with-standards System.}

This system is the one most commonly found in the Midlands and South of England. The overwood consists of seedling trees of oak, ash, larch, birch, or any other species which only throw a light shade; and the underwood of hazel, ash, sycamore, sweet chestnut, oak and beech, or any other broad-leaved species which will bear the shade thrown by the overwood. The rotation of the coppice is fixed at the age at which the produce is most easily saleable, and the total area divided by the rotation gives the area to be cut annually.

Each year the coppice on this area is clean cut. Then the standards are thinned, taking out all mature trees and those which are diseased or very badly shaped. The number of standards to be left depends upon the size and age of the existing trees. In the Highmeadow woods, where the rotation is 35 years, the normal number of standards to be left per acre after each cut is as follows :-

$$
\begin{aligned}
\text { Aged } 35 \text { years } & =40 \\
, 70, & =20 \\
, 105, & =10 \\
, 140, & =5
\end{aligned}
$$

Where trees of the larger sizes are not to be found, a greater number of the younger classes are left standing. In most woods the standards are left equally distributed over the area, 
but better timber is obtained it they are left in groups, each group consisting of standards of the same age.

The age of the standards will always be some multiple of the rotation of the coppice; thus, if the coppice rotation is twenty years, the standards on the area cut in any year will be twenty, forty, sixty, eighty, and one hundred years, and so on up to the desired age. While cutting the coppice care is taken not to cut any saplings which will do for standards; if these are absent good coppice shoots may even be left for this purpose. If no saplings worth leaving can be found, young trees are planted in the spaces to form future standards. When the coppice has formed thicket again, periodical cleanings should be made to clear the saplings from any shoots which are threatening to damage them.

In a well-managed coppice-with-standards there should be found on any area standards of several ages, though this is seldom the case in English woods owing to the neglect to plant in new saplings, or to allowing them, if planted, to be killed out by the coppice.

Existing woods have often two faults: first the standards, usually oak, are grown singly and far apart, with the result that they are much branched and produce short timber only; secondly, the coppice consists chiefly of hazel, which is now of no value. Such woods may be improved as follows. After a cut has been made, assuming that the rotation is twenty years, about 400 strong plants should be planted per acre in groups. About 100 of these may be oak, 250 ash, and 50 larch, sycamore, and other desired species. These grow on and should be visited every four years to cut back all coppice shoots injuring them. At the next cutting about 50 of the best of these trees, now twenty years old, will be reserved, about 25 being oak, and $2.5 \mathrm{ash}$, larch, \&c., another 400 plants being planted as before. At the third cut the 50 standards, now forty years old, will be thinned where necessary, leaving about 30 , of which half are oak. At the fourth cut they are reduced to 15 
per arre, and at the fifth cut, when the trees are eighty years old, they are reduced to 5 , and these must all be oak, the ash and larch being now finally removed. These 5 oaks will be left till they are 100 years old and will then be cleared, or, if desired, one or two of them can be left to I 20 or 140 years. Another 400 plants are put in after every cut, and each lot is treated as above. Thus, after one complete rotation of one hundred years of the overwood, there will be on an acre immediately before cutting:-

5 oaks 100 years old.

5 oak and io ash, \&c., 80 years old.

15 oak and I 5 ash, \&c., 60 " ,

25 oak and 25 ash, \&c., 40 ", ,

300 to 400 tellers or young standards of the age of the coppice, 20 years.

When the felling is made the following are removed :-

5 oaks

Io ash, \&c.

Io oak and 5 ash, \&c.

to oak and to ash, \&c.

All except 50 trees

All the coppice
100 years old.

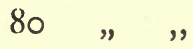

60

40 " "

$20 "$,

20 ", "

and the correct number of each age is left to grow another rotation.

The oak, ash, and other broad-leaved trees cut at the age of twenty years, of which there will be about $3 \mathrm{co}$ per acre, will coppice and form an improved underwood in the future, and in the course of time the hazel will be got rid of.

As the standards will all be in small even-aged groups they will form better timber than has been usually obtained from such woods. Larch does very well over a dense coppice and often escapes disease when grown in this way, as may be seen in the Crown woods at Tintern. Groups of any other species can be introduced as desired. 
Coppice-with-standard woods suffer very little from frost, drought, storms, insects, and fungi, and if the cover is kept dense the fertility of the soil is well preserved. The only real danger is from rabbits, which often completely destroy the coppice. These must, therefore, be kept within reasonable limits.

\section{Woods for Timber and Game Coverts Combined.}

A modified form of coppice-with-standards will often be found the best on estates where pheasant preserving is important, and when the management of the woods must be such that the sport is not interfered with. With a little arrangement there is no reason why a good revenue should not be obtained without friction between the gamekeeper and woodman, provided always that the owner insists on rabbits being kept down. In pheasant preserves it is essential that the underwood should be full and dense, and therefore the rotation should be such that this effect is obtained. With long rotations the underwood gets thin below, and therefore about twenty years should be fixed upon.

In order to provide food for the pheasants, groups of such trees and shrubs as crab-apple, hawthorn, mountain-ash, elder, holly, cherry, sloe, privet, snowberry, and barberry, can easily be formed on ride sides, on the margins of woods, and here and there in blank spaces without unduly reducing the area for the growth of more valuable species. A few spruce should be grown in an open manner, three or four together to provide roosting places. These trees should be allowed to branch right down, and clean timber is not expected from them. With this modification, the crop should be formed as described under coppice-with-standards.

Another essential matter is that the woods shall be disturbed as little as possible and only at intervals of a few years. This can be ensured by carrying out the cuttings as indicated in the following example:-

Let us assume that there are two hundred acres of woods in 
four blocks of 50 acres each, and that the rotation chosen is twenty years, the work being carried out as already described. The average annual cut will be ten acres, so that the whole area will be worked over once in twenty years.

Then the first cut is made in block I

\begin{tabular}{|c|c|c|}
\hline "second & $"$ & " \\
\hline third & " & \\
\hline " fourth & ", & ", \\
\hline fifth & , & ", \\
\hline
\end{tabular}

and so on.

Thus in any year three blocks are left entirely alone and work goes on in one only. Arrangements should be made to have this block shot over early in the season before the forest operations commence.

At the end of twenty years, block I will contain 10 acres each of woods $20,16,12,8$, and 4 years old.

Block 2 will contain woods $x 9$, I 5, II, 7,3 .

Block $3 \quad, \quad, \quad$ " $18,14,10,6,2$.

Block $4 ", \quad, \quad$ I $7,13,9,5$, I.

Thus each block will have old, middle-aged, and young coppice and will give excellent cover. Shelter belts should be left on the north and east sides to keep off cold winds, and the cuttings should proceed against the prevailing wind direction, usually therefore from northreast towards the south-west. By doing this young shoots and standards will be protected from wind by the uncut wood to the windward side.

This method can easily be made to suit all woods, whatever their size or arrangement. It matters not whether all the woods are in one large block, in which case they can be divided into four or more moderate-sized parts, each worked as above as if it were a separate block; or whether they consist of a large number of small blocks, in which case two or more can be grouped together for the arrangement of the cuttings. 


\section{Conversion of Coppice-with-standards into High Forest.}

In many localities where coppice is now unsaleable the owner may wish to convert his existing coppice-withstandard woods into high forest. Where the underwood is hazel the simplest method of doing this is to convert the wood gradually, taking so long about it that by the time the wood has been worked over once the first formed plantations of the new crop will come in for felling. If conifers are planted this period should be at least forty years, and the area cut annually will be the total area divided by 40 . This area of the oldest coppice is cut, and the standards are also cleared, with the exception of any groups young enough to take their place in the new crop. It is, however, useless to leave single trees, or very small groups, as these will never form good timber. The area is then planted up with larch, ash, Douglas fir, spruce, Corsican or Scotch pines, or other quick-growing trees according to the soil. The future treatment consists of keeping back the coppice shoots, which should be cut in the third year after planting, and it may be necessary to repeat the operation up to the sixth year. After this the seedling plants will be able to keep above the coppice shoots, which will then gradually die out. In each year of the rotation another area is dealt with, till in the fortieth year the whole of the coppicewith-standards is replaced by high forest.

Where the existing underwood contains a large proportion of oak, ash, sycamore, chestnut, or beech, it can be converted into a false high forest which will grow to a paying size before it is finally removed and replaced by seedling trees. In this case the area of ripe coppice should not be clear cut, but a heavy thinning should be made among the shoots, reducing the number to one or two on each stool, the straightest and stoutest being left. All the large size standards are also removed, leaving the younger and well-grown ones. The 
standing crop may then be allowed to grow on, with necessary thinnings periodically, till it is fifty to sixty years of age, by which time a considerable amount of saleable timber will be obtained. It can then be clear cut and the new crop formed by planting, or in some cases it will be possible to obtain natural regeneration. This method delays the formation of true high forest, and the timber will not be first-class, as the trees are stool shoots and are often rotten at the butt; on the other hand the cost of planting is saved, and small stuff which may be hardly saleable is allowed to grow on to a fair size. This method is being carried out with success in oak and beech woods on the Tintern estate, belonging to the Crown, where the coppice is now some twenty-five years old, the intention being to clean cut the crop at fifty or sixty years of age.

When carrying out this method, care must be taken not to convert too large an area at one time. Thus if the total area is 600 acres and the old coppice rotation was twenty years, the area cut annually has been 30 acres. If now this area of 30 acres is converted annually, at the end of twenty years the oldest wood will only be forty years of age, while the crop will probably not mature till sixty years is reached. There will thus be nothing to cut from the fortieth to the sixtieth year. To prevent this, one must convert a smaller area annually.

In this example, if the future wood is considered likely to be mature at sixty years, it will be necessary to take forty years to convert it, because the oldest coppice is already twenty years old to start with. Thus I5 acres must be converted annually.

The best procedure is to select 150 acres of the oldest coppice and to convert this in the first period of ten years. Another $15^{\circ}$ acres of the next oldest coppice is left alone, to be converted in the second period of ten years. The remaining 300 acres is managed for the first twenty years as ordinary 
coppice-with-standards, and is taken in hand for conversion in the third and fourth periods.

In the fortieth year the wood will consist of forty 15 -acre blocks, covered with woods from twenty to sixty years old, looking like high forest though really consisting of coppice shoots.

Henceforward only to acres would be regenerated annually unless the rotation is to be altered. 


\section{CHAPTER VIII}

\section{PROTECTION OF WOODS AGAINST DESTRUC- TIVE ANIMALS, BIRDS, AND INSECTS.}

\section{Animals.}

HARES and rabbits, squirrels, mice, and voles, are the most destructive animals in the British woods.

Hares and rabbits do damage by gnawing the bark of young plants and by biting off the buds and young shoots; they also eat the bark of large-sized trees of beech and other smooth-barked species. Nearly all species are attacked with the exception of lime, which has a stringy bast; Corsican pine also appears to be avoided. When rabbits are at all numerous it is useless attempting to raise plantations, as there is little or no chance of obtaining a full crop. Wherever serious forestry is to be attempted it is absolutely necessary to get rid of them, as otherwise extensive fencing with netting must be done, the cost of which will run away with a large proportion of the profits. Where the owner desires rabbits, it is far preferable to enclose them in a warren and to get rid of them elsewhere, than to have to fence every young plantation. If the owner does not wish to do this, he must understand that his woods are never likely to pay. When woods are netted against rabbits it is only fair that the cost of the work should be debited to the sporting account, and not against the woods. The easiest way to get rid of rabbits is to persistently shoot them; but it will also be necessary to dig out those that escape the gun, as even one rabbit can do immense destruction in a young plantation. They must also be trapped. Where they are few in number any rare or specially valuable trees 
may be painted with one of the preparations on the market, or can be enclosed with a small ring of wire netting.

Wherever netting has been erected plantations should be periodically visited, preferably when there is snow on the ground, and if any trace of rabbits is found the animals must be hunted down and killed. Foxes may be encouraged.

Squirrels. These do more damage than is generally imagined; they eat fruit and seeds, cotyledons and buds; they bite off young shoots, girdle trees by eating the bark, and destroy eggs and young birds. Squirrels especially attack Scotch pine, but larch suffers considerably by being barked some twelve to fifteen feet below the top, which then dies or is broken off in the next gale. Squirrels should therefore be kept down to a reasonable number by shooting them, though they do a certain amount of good by carrying and dropping seeds, thus aiding natural regeneration.

Mice and voles. Voles are distinguished from mice by their thicker, shorter head, by having their ears buried in their fur, and by their short legs and tails. These animals do damage by burrowing in nurseries and young plantations, just under the ground, thus uprooting young plants. They eat fruit and seeds and cut through the roots of plants of some size, while they sometimes aid the spread of fungi by carrying the spores from one root to another. During winter they may gnaw the bark for some inches above the ground. They are especially harmful in nurseries, often eating considerable quantities of acorns and other large seeds. Ordinarily the damage done is small, but occasionally they increase rapidly and they then do great harm. To protect woods and nurseries against these pests, the following measures may be taken.

I. When mice are abundant, do not sow acorns or other large seeds in autumn, but keep them till spring, when they germinate quickly.

2. In nurseries sow broadcast instead of in drills and scatter small pieces of gorse in the seed-beds, among the seeds. 
3. Roll the seed well in red-lead before sowing.

4. Protect mice-eating birds, such as kestrels and owls, which destroy large numbers.

5. In nurseries lay spring traps about on the seed-beds and visit daily to remove the mice which are caught. The traps should be attached with strong cords to pegs.

Another good plan is to bury glass jam-pots in the ground with their tops level with the surface. Into these place a few grains of wheat as a bait; the mice fall in and cannot get out.

6. If great care is taken poison may be used, but there is always danger of this being taken by other animals. When used it should be placed in short narrow drain-pipes, so small that only mice can enter them.

\section{BIRDS.}

The great majority of birds are useful, as they eat a great number of grubs and injurious insects, and care should therefore be taken not to destroy them without careful thought. At certain times of the year, more especially in nurseries, birds may be a nuisance, but it is usually better to protect the seed-beds with netting rather than to shoot the birds, which are probably the woodman's best friend at other times of the year.

Pigeons, doves, jays, and chaffinches, are decidedly destructive; they eat great quantities of seeds and also destroy buds and seedlings in nurseries, and should be kept down by shooting. Most of the other birds do more good than harm.

Nurseries may be protected from damage by birds as follows:

I. Roll the seed well in red-lead before sowing.

2. Cover the seed-beds with wire netting.

3. Use scarecrows.

4. Fire off blank cartridges, or if necessary shoot the birds.

Woodpeckers do damage by making holes in standing trees, but on investigation it is nearly always found that trees so attacked are already rotten within, or have been attacked 
by bark beetles. The woodpecker eats these beetles and thus does good. On the whole we may say that woodpeckers do inore good than harm, and should be preserved.

The following list, compiled from Schlich's Manual of Forestry, classifies birds from a forester's point of view. Those in column 2 do damage by killing useful birds or by eating their eggs, and those in column 3 do a certain amount of damage in various ways, but on the whole do more good than harm.

\begin{tabular}{|c|c|c|c|}
\hline $\begin{array}{l}\text { I. Decidedly } \\
\text { harmful. }\end{array}$ & $\begin{array}{l}\text { 2. Indirectly } \\
\text { harmful. }\end{array}$ & $\begin{array}{l}\text { 3. Deserve con- } \\
\text { ditional pro- } \\
\text { tection. }\end{array}$ & $\begin{array}{c}\text { 4. Deserve un- } \\
\text { conditional pro- } \\
\text { tect:on. }\end{array}$ \\
\hline $\begin{array}{l}\text { Capercailzie. } \\
\text { Black game. } \\
\text { Hazel-grouse. } \\
\text { Wood-pigeon. } \\
\text { Stock-dove. } \\
\text { Turtle-dove } \\
\text { Jay. } \\
\text { Nutcracker. } \\
\text { Hawfinch. } \\
\text { Greenfinch. } \\
\text { Chaffinch. } \\
\text { Brambling. } \\
\text { Siskin. } \\
\text { Crossbill. } \\
\text { Parrot Crossbill. }\end{array}$ & $\begin{array}{l}\text { Shrikes. } \\
\text { Magpie. } \\
\text { Raven. } \\
\text { Most hawks. }\end{array}$ & $\begin{array}{l}\text { Bullfinch. } \\
\text { Robin. } \\
\text { Larks. } \\
\text { Thrush. } \\
\text { Blackbird. } \\
\text { Jackdaw. } \\
\text { Common Crow. } \\
\text { Hooded Crow. } \\
\text { Rook. } \\
\text { Honey buzzard. } \\
\text { Common buzzard. } \\
\text { Kestrel. } \\
\text { Woodcock. } \\
\text { Snipe. } \\
\text { Golden plover. } \\
\text { Lapwing. }\end{array}$ & $\begin{array}{l}\text { Cuckoo. } \\
\text { Woodpeckers. } \\
\text { Wryneck. } \\
\text { Night-jar. } \\
\text { Swift. } \\
\text { Tree-creeper. } \\
\text { Nuthatch. } \\
\text { Swallows. } \\
\text { Wagtails. } \\
\text { Pipits. } \\
\text { Hedge-sparrow. } \\
\text { Gold-crest. } \\
\text { Wren. } \\
\text { Redstart. } \\
\text { Stonechat. } \\
\text { Wheatear. } \\
\text { Flycatcher. } \\
\text { Titmice. } \\
\text { Starling. } \\
\text { Owls (except } \\
\text { eagle-owl). } \\
\text { Black-headed } \\
\text { gull. }\end{array}$ \\
\hline
\end{tabular}

Note.-Nisbet in The Forester places robin in column 4, and woodpeckers, greenfinch, and siskin in column 3. He also includes roller, hoopoe, warblers, nightingales, whitethroat, and oriole as decidedly useful birds.

\section{INSECTS.}

Insects as a general rule pass through a series of changes before reaching maturity. Commencing as an egg, this hatches out into a larva, grub or caterpillar, which is a stage in which 
growth and active feeding takes place; the larva often changes its skin or moults several times, and then turns into a pupa or chrysalis. In this stage it remains inactive does not feed, and is often enclosed in a cocoon. Finally, out of the pupa emerges the imago, or perfect insect. The female lays eggs, and a new generation then commences. To thoroughly understand the above, the woodman should collect a few common caterpillars from his garden and should place them in a box covered with muslin. If they are kept well supplied with fresh food, the leaves of the plant they were found eating, they will go through all the above stages and can be easily observed.

Insects do no harm in the egg or pupa stage; with the majority of species the damage is done in the larva or grub stage, whilst in some cases the perfect insect also does damage. The time which elapses between the egg stage and the fresh production of eggs is termed a generation; this may be annual, or there may be several generations in the year, while in some cases there is only one generation in several years.

Most insects are injurious, some injuring forest trees, others agricultural crops. Only very few are useful in forestry. The damage done depends on the species, and may be very slight or so bad that large areas of woods are destroyed. Injurious insects may do damage by eating leaves, flowers, or fruits of trees, by gnawing the roots or by boring in bark or timber. Some attack dead trees only and are therefore not so injurious as those which attack and kill healthy trees.

As a general rule conifers suffer from insect attack more than broad-leaved trees.

There is no doubt that a far larger amount of damage is done by insects than is generally suspected, and it is a very necessary part of the woodman's duties, too often neglected, to keep a sharp look out for insect attacks and to take such measures as is possible against them.

Prevention is always better than cure, and danger can be 
largely reduced by a careful attention to the following general rules, the great thing being to keep the woods in a clean, healthy condition.

I. Careful choice of species to suit soil and climate.

2. Formation of mixed woods, more especially mixing broad-leaved trees with conifers. Pure woods on a large scale are especially susceptible to insect attacks.

3. Early and frequent thinnings should be made to remove all dead and dying trees.

4. Careful preservation of the fertility of the soil, by mixing soil-improving trees with light-demanders.

5. Removal of all trees broken by wind or injured by fire.

6. Avoidance of large felling areas in one place. It is, for instance, better to cut ten acres in one part, and ten acres in another part of the forest, than to clear twenty acres in one spot. Moreover, a cutting should not be made adjoining a previous one till the young trees on the latter are well established; this is specially important in conifer woods.

7. All material felled should be rapidly removed from the wood, and should not be left lying about.

8. All insectivorous birds should be protected and encouraged. These are included in the list already given, under the headings ' useful' and 'rather useful.'

To encourage birds a few hollow trees and clumps of underwood should be left standing in the woods, here and there, to provide nesting-places.

Toads and frogs are useful in nurseries, and spiders are great destroyers of insects.

With regard to remedial measures, it is unfortunately very difficult to take steps against most species, owing to the heavy expense of doing things on a large scale. In orchards and in small plantations remedial measures will often be successful, but in a large forest it is seldom possible to fight effectively against these pests. The following measures may be tried in certain cases :- 
I. Collection and destruction of larva, pupa, and perfect insect. With a knowledge of the life history of the insect, the woodman will choose that stage in which it is easiest to destroy it.

2. Preparation of traps. A few dead or sickly trees are left standing in the woods, or felled logs are left here and there. These are visited periodically, and when found to be full of the insects they are burnt.

3. Grease bands may be put round the trunk of trees to catch insects, such as the winter moth, which climb up from the ground and cannot fly.

4. In orchards or in nurseries of specially valuable species, spraying with an insecticide may be tried. Paraffin emulsion is often very successful; to make it, dissolve one pound of soft soap in half a gallon of boiling water, add one gallon of paraffin oil, and churn this well by using a garden syringe till the oil is well mixed into the soapy water. For use, dilute by gradually stirring in twelve to fifteen gallons of water.

Other measures will be indicated when dealing with each insect.

Although very little can be done by the woodman, it is comforting to know that parasitic insects, diseases, birds, damp and cold weather, kill off myriads of injurious insects which would otherwise multiply enormously. It is not possible in this book to enter into great detail regarding the various insects, but the following short notes deal with a few of the worst to be found in the British woods. Further details about some of these pests can be obtained in the leaflets issued by the Board of Agriculture, which are given away free. A list of these should be obtained by the woodman, who can then ask for those leaflets he requires. 
Coleoptera (Beetles).

The Cockchafer (Melolontha vulgaris).

This beetle is common in our woods, and does damage in forest nurseries. It is a large reddish-brown beetle, about one inch in length; it appears in April and May, and lays eggs in the ground, preferring bare loose soils, such as ground recently dug. The grubs hatch out from four to six weeks afterwards, and live in the ground three or four years, eating the roots of plants. The grub is a large white curved one,

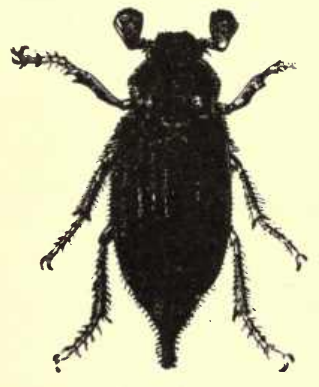

$a$
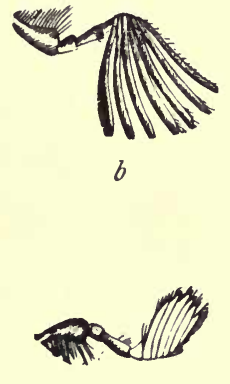

c

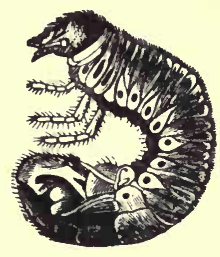

$d$

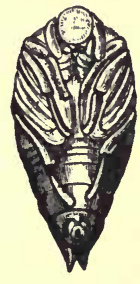

$e$

Fig. I. Melolontha vulgaris, Fabr.

$a$ Imago (male). $b$ Antenna of male with 7 lamellae. $c$ Antenna of female with 6 lamellae. $d$ Grub. $e$ Pupa (ventral surface).

and is often found while digging nursery ground, or when taking up turf. The perfect beetle flies off to the surrounding woods and does some damage by eating the leaves of broadleaved trees. It is, however, in the grub stage that the worst damage is done, as a few grubs in a seed-bed will bite off the roots of many plants, which droop and die. The roots of all species are eaten. The only effective protective measure against this pest is to persistently collect and destroy all grubs found in the nursery whenever any part is being dug over. If they get into a seed-bed this will be suspected, as seedlings here and there will droop, and if pulled up will be 
found to have had their roots bitten off. If this happens, the best procedure is to systematically go through the seed-beds, running the plants up between the fingers. Loose plants will be pulled up without damaging the sound ones. When a loose plant is found, dig down at and round that spot with a narrow trowel. Very often the grub will be found at work and can be destroyed. All beetles found should also be destroyed. To aid collection of grubs a trench should be dug round the nursery and filled with humus; this should be turned over every now and then, and probably many grubs will be found. Birds, especially rooks and starlings, eat the
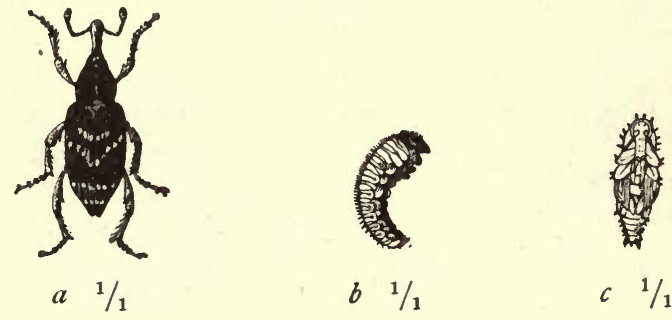

Fig. 2. Hylobius abietis, Fabr.
$a$ Imago.
$b$ Larva.
$c$ Pupa.

grubs and beetles, while moles also eat quantities of the grubs, but are, unfortunately, undesirable in a nursery.

Pine weevil (Hylobius abietis).

This beetle is from three-eighths to half an inch long, dark brown to black, with two or three golden stripes across the back. Its head has a long snout. The beetle is found from May to September, and it lays its eggs on stumps and roots of conifers, which have been felled one or two years. The grubs eat galleries in the bast and sapwood of the stumps, and finally turn into pupae in them. As the grubs pass their life in stumps they do not do any harm, but the perfect beetles, which come out in the second year, attack young plants of 
Douglas fir, pines, spruce, and other conifers, preferring those from three to six years old. They gnaw the bark off the young stem, exposing the wood in patches. Very often the plants are girdled, and in some cases are completely peeled. On older plants only bark from one to five years old is eaten, as six-year-old bark is too hard for them. The beetle is very destructive and often causes the failure of large plantations. The following protective measures may be tried:-

I. The areas cut should be small and isolated, a belt of old wood being left between successive cuts. 'If then the beetles get into one area, they are more easily prevented from spreading into other young plantations.

2. Stumps of conifers should be extracted, but as this is usually too expensive, all rubbish should be piled and burnt on them, when clearing an area for planting, to kill the stumps.

3. Any area containing conifer stumps may be left for four years unplanted after felling, as the stumps and roots will then dry up, and the grubs will die owing to want of food. While the area is blank, sheep and cattle may be admitted for grazing. This measure is very effective, but four years of growth are lost.

When beetles have actually appeared, the best remedial measures are:-

I. To employ children to collect them off the plants. If persistently done, this will keep them down.

2. To put down traps in June, consisting of smooth barked pine sticks three feet long and two to four inches thick. These should be buried in the ground, here and there over the area, obliquely so that one end is ten inches deep and the other two inches out of the ground. The beetles lay their eggs in these and in September the sticks are pulled out and burnt. A stake put at every trap will enable it to be easily found. 
3. Pieces of bark twelve inches square may be placed on the ground bast downwards, with stones to keep them in place; about fifty per acre are required. Children can visit these bark traps daily and collect the beetles found under them; the bark should be renewed when it loses its resinous smell.

Pine-Beetle (Myelophilus piniperda).

This is one of the commonest of our destructive beetles. It is about $\frac{1}{6}$ inch long, and dark brown or black in colour.
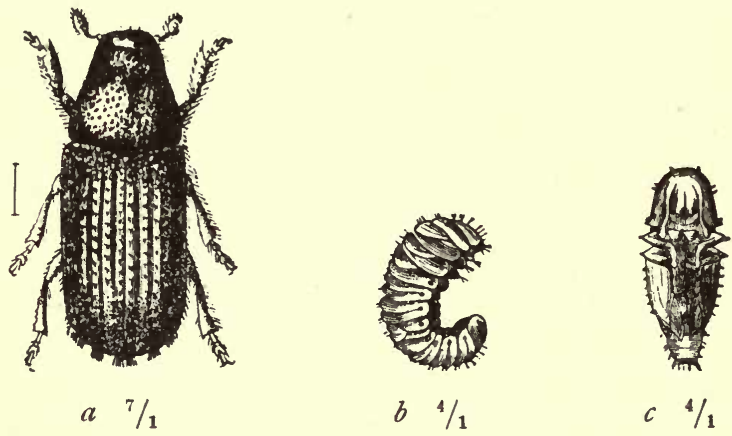

Fig. 3. Myelophilus piniperda, L.
$a$ Imago.
$b$ Larva.
$c$ Pupa.

Eggs are laid in spring in felled stems and dead or dying trees of Scotch and other pines, large trees being preferred. The grubs hatch in April or May, and the beetles appear in June or July. The insect does two kinds of damage. The grubs eat out galleries in the bast; while the beetle itself does even more harm by boring into the pith of young pine shoots a few inches from their end, eating out a gallery an inch long. These shoots fall off when the next heavy wind comes, and thus the tree loses a great deal of its foliage. The broken twigs may often be found in thousands lying on the ground. 
The following protective measures may be tried:-

I. Carry out frequent thinnings to remove dead and sickly trees.

2. Clear all felled timber from the forest by April.

3. Periodically, from February to September, fell a tree or two here and there to act as traps. Strip the bark off them as soon as grubs are found at work, and burn the bark.

4. Standing trees found to contain the grubs should be felled and the bark stripped and burned.

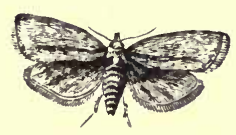

a $1 / 1$
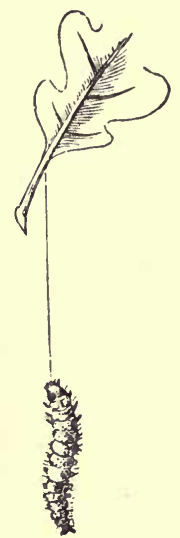

b $1 / 1$

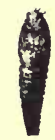

$61 / 1$

Fig. 4. Tortrix viridana, L.

$a$ Moth. $b$ Caterpillar suspended by a thread. $c$ Pupa.

\section{Lepidoptera (Moths).}

Oak-leaf roller moth (Tortrix viridana).

This is a small moth, with its fore wings light green, and hind wings light grey, which may be found in thousands in almost any oak wood in June. The caterpillar is about half an inch long, greenish-grey to dull green, with its head and anal flap black, and with warts on its back. The caterpillars appear in April and May, often in enormous numbers, and spin threads, by which they let themselves up and down from 
the branches; they very often completely defoliate several acres, chiefly attacking the mature trees. At the beginning of June they roll up a leaf and pupate inside the cover thus formed. Owing to the destruction of the foliage the tree may form very little timber in the year of attack, and the formation of acorns may be prevented. Fortunately, the second flush of leaves which appear in July are never attacked, and the trees are therefore seldom killed.

Unfortunately, no remedial measure is possible on a large scale. The destruction of the pest must be left to birds, especially starlings, and to unfavourable weather.
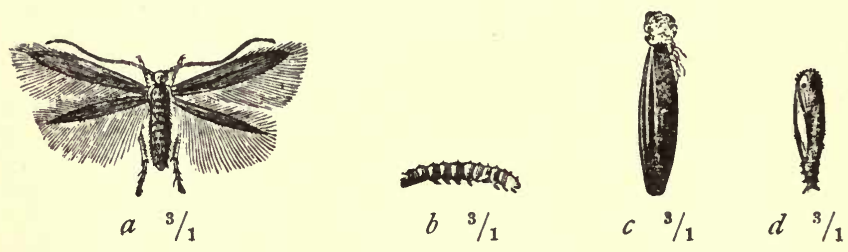

Fig. 5. Coleophora laricella, Hbn.

$a$ Moth. $b$ Caterpillar. $c$ Larval case. $d$ Pupa.

\section{Larch-miner moth (Coleophora laricella).}

A very small moth, with a wing expansion of about $\frac{3}{8}$ inch. The wings are very narrow, shining ashy grey with very long fringes. The caterpillar is dark reddish-brown, about $\frac{1}{8}$ inch long. The moth flies in May and June, and lays its eggs singly on larch needles. The caterpillars hatch in June and grow till September, boring into young larch needles to about half their length, so that the upper ends turn yellow and shrivel up, looking as if they had been touched by frost. In September the caterpillar prepares a case out of the dry part of a needle and hibernates in this, near the tips of the twigs, or in cracks in the bark. It pupates in spring after enlarging the case by attaching a second hollowed-out needle to the first. Owing to its appearing in very large numbers year 
after year in the same place, the foliage of the larch is often so reduced that the health of the tree is affected, and it then becomes liable to attack by the larch canker. It must therefore be considered as a very serious pest. No remedial measures can be taken on a large scale, but the chief object of the woodman should be to keep the larch in healthy condition by the accepted sylvicultural methods. Late frosts, and wet or cold weather, kill off millions of this insect.

\section{Hymenoptera (Sawfies).}

Pine sarufly (Lophyrus pini).

The larva of this insect has twenty-two legs (whereas that of a moth has sixteen), and is of a dull green colour. It is social, and feeds in colonies. The sawfly appears in April and May, and again in July and August. The female does not appear to fly, but crawls along on the twigs and needles of pines. She cuts slits into pine needles and lays an egg in each slit.

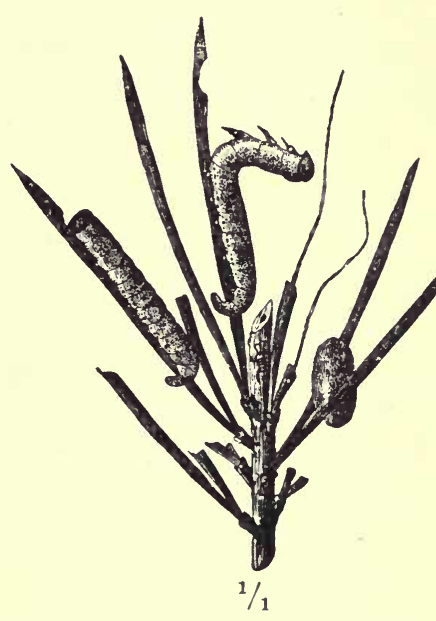

Fig. 6. Pine needles, with larvae and cocoon of L.pini, L. The larvae hatch out in May and June, and the second brood in August and September. They pupate in long leathery dark brown cocoons. They attack chiefly Scotch pines, preferring sickly trees, and eat the needles in companies of eighty to one hundred, leaving the midrib untouched. When disturbed they bend the front part of their bodies into the shape of the letter $\mathrm{S}$.

The insect is very destructive, but unfortunately it is difficult to deal with on a large scale. In young plantations 
men might crush the larvae with gloved hands, or the infested shoots could be cut off and burnt; otherwise the ordinary rule of keeping the woods healthy and clean, and of protecting birds, must be depended upon.

\section{The large larch sawfly (Nematus Erichsoni).}

This insect has recently done serious damage in the south of Scotland, Cumberland, and Wales, and appears to be so destructive that it has been placed on the list of insects which must be reported to the Board of Agriculture under a penalty of £ro. The woodman should obtain leaflet 186 , and also a memorandum issued by the Board. The sawfly measures $\frac{3}{8}$ inch and is, on the whole, black in colour. The caterpillar measures $\frac{3}{4}$ inch, and has a black hairy head, a greenish body, with twenty legs. The caterpillars eat the needles of larch in July and August, and may completely defoliate the trees. They prefer trees from twenty to seventy years of age. This makes it difficult to carry out any remedial measure, as the caterpillars are out of reach. When they appear on small trees they should be squeezed in a gloved hand, or infested shoots may be cut off and burnt. On dull days the trees might be jarred to bring down the caterpillars. Full details about this pest will be found in leaflet $\mathbf{I} 86$.

\section{Hemiptera (Plant lice and scale insects).}

Spruce gall aphis (Chermes abietis).

This very small insect produces a gall, somewhat like a small fir cone, on spruce twigs. These galls are at first soft and green, but afterwards become hard and brown; they are usually on one side of the twig, which becomes curved and stunted. Young plants of spruce may suffer considerably if there are a great number of galls on them ; though, fortunately, the leading shoot is seldom attacked. It is believed that one generation of this insect appears on the larch in the form of the larch aphis, and it is therefore all the more necessary to 
take measures against it. The young insects are within the gall when it is soft and green, and galls in this stage on nursery plants and young transplants might be cut off with a pair of scissors and burnt. It is useless to remove old galls as these are empty.

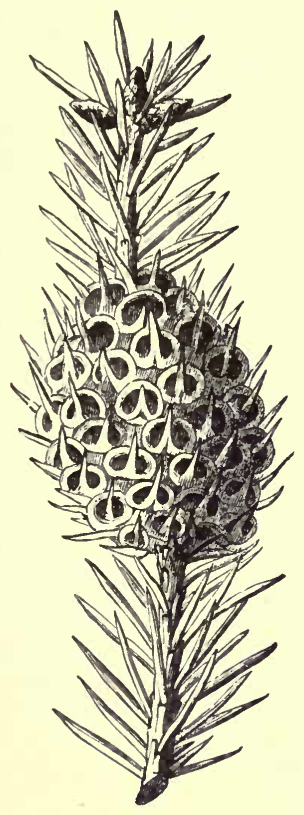

Fig. 7. Gall of Chermes abietis, L., on a spruce-twig. (Natural size.)

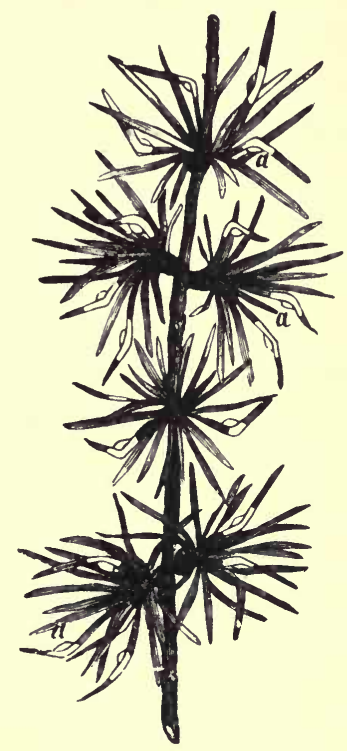

Fig. 8. Larch-shoot attacked by Chermes laricis, Hart. (Natural size.) $a$ Insects feeding on the needles, which show a characteristic angular bend.

The Larch aphis (Chermes laricis).

This aphis sits and feeds on the needles of larch. The needle is bent over at the spot where the aphis is feeding. At first it looks like a black spot on the needle, but afterwards becomes covered with a woolly down, and, if numerous, the larch look as if sprinkled with snow. When numerous the health of the trees suffers, and, moreover, they are probably more apt to be attacked by the larch canker, the spores of the 
fungus finding a ready inlet through the wounds caused by the aphis. At first the insects are wingless, but they acquire wings in late summer, and then spread to other larch and to the spruce.

Nothing can be done on a large scale against this insect, and one must trust to keeping larch healthy by growing it only in favourable places. Nursery plants, if attacked, may be sprayed with paraffin emulsion.

Beech woolly aphis (Coccus fagi).

This scale insect attacks beech, and is becoming a serious pest, often killing fine old trees. It is covered with a white felt, which is very conspicuous on the bark where the insect sits and sucks the sap. Valuable trees in parks may be saved by scrubbing them from top to bottom, wherever the insect is seen, with the paraffin emulsion. Further details regarding this pest may be found in the Board of Agriculture leaflet No. 140. It is apparently amenable to some influence, possibly the weather, as there has lately been observed a considerable diminution of the pest in some of the beech woods in Buckinghamshire. 


\section{CHAPTER IX}

\section{PROTECTION OF WOODS AGAINST WEEDS AND FUNGI}

WEEDS.

ALL plants which are not required in the forest may be termed 'weeds', whether they are trees, shrubs, or annuals.

The most common weeds in our woods are bramble, heather, wild briar, bilberry, ivy, traveller's-joy, honeysuckle, bracken, gorse, foxgloves, broom, and grasses. Sometimes such plants as birch, willows, aspens, blackthorn, whitethorn, and holly may also be considered as weeds where they interfere with the growth of more valuable species.

Most of these weeds damage forest plants by closely surrounding and covering them, thus depriving them of light, air, and rain. Climbing plants smother or wind round valuable trees, and, in addition to depriving them of light, they spoil the shape of the stem, which often grows into a corkscrewlike shape.

Bracken and similar weeds are often laid flat over the plants in winter by the weight of snow, and thus bend them and spoil their shape. Weeds also take up valuable mineral matters from the soil and thus impoverish it; although these substances are returned to the soil when the weeds die, yet too often a new crop of weeds again comes up and the mineral matters are therefore not available for the forest trees. A dense growth of grass or annuals prevents dew and light rain from reaching the ground, and may thus be harmful in dry years. Weeds, in addition, harbour mice and injurious insects, and are a great source of danger with regard to fire.

It is therefore of importance to keep woods as clear of weeds as possible. Before planting a blank area they may often be cheaply got rid of by burning them as they stand, 
and this is the best mode of dealing with a thick growth of heather, gorse, or bracken, and it has the advantage of destroying insects and fungi. Where burning is impossible, as for instance when the ground is already planted, weeds must be cut. This is usually best done towards the end of June or in July, as they are then in full growth and do not so easily recover. Bracken should be dealt with while the frond is soft and before it expands; it can then be easily broken with a stick and need not be cut. Brambles should be beaten down, and not cut, as cutting increases the number of suckers; nevertheless, if these new suckers are also cut regularly, the brambles will die out in two or three years' time. Foxgloves should be cut when in flower.

In a young plantation this cutting of weeds will be necessary annually for two or three years after planting. After that period the trees will usually form cover over the weeds, and low growing weeds need not then be taken notice of, as they will die in course of time.

When the trees are forming a thicket, only climbing weeds such as honeysuckle and traveller's-joy need be cut back.

Once the thicket stage is formed, a densely planted wood becomes clear of weeds, and the ground remains clean till the woods open out naturally at about the twentieth to fortieth year. Under light-demanders there usually then springs up a new crop of weeds of some sort, and this is an indication that the time has come for underplanting with beech or some other shade-bearer, as if there is light enough for weeds there is also enough for beech.

Under certain conditions a moderate growth of certain kinds of weeds may be of more good than harm. Where, for instance, there is a growth of birch, sallow, aspen, coppice shoots of any species, or even broom and gorse, in a young plantation, these should not be cut without taking into consideration the fact that they may be of use in affording shelter from wind or frost to the young forest trees. Where this 
appears to be the case they should not be cut wholesale, but only those which are actually doing damage need be destroyed. The rest may be left standing till their shelter is no longer required, and may then be cut out.

A very good instance of this sheltering effect of what would ordinarily be called weeds can be seen in the Crown woods at Tintern, where an excellent crop of larch, Douglas fir, and Scotch pine, in groups, over about ten acres in all, has been raised on a somewhat exposed position at an elevation of 850 feet by leaving coppice shoots of oak and other woody weeds on the ground, the crop being planted between them. The area was gone through occasionally and, at very small expense, just those shoots which were actually injuring a tree were cut back. The trees have now been planted eight years, and are forming thicket, and the coppice shoots will be left alone to die out. This example shows how advantage may be taken of coppice shoots or other weeds to give valuable shelter ; another advantage is that the great expense of wholesale cutting of weeds, which usually amounts to about $£$ I per acre on strong soil, is saved.

Herbaceous weeds may also be left alone unless actually interfering with growth.

It is worth noting that where no regeneration is required, and where no planting is being carried out, brambles are useful because they keep the soil moist and prevent leaves being blown away. They are a sign of moisture in the soil, and are absent in open woods with a dry soil, though they are found in fairly thick woods if the soil is rich and moist. Under such circumstances they are not killed out by the cover unless this is very dense, low, and continued for five or six years, as the seeds lie dormant for about four years.

\section{FUNGI.}

Fungi are plants which belong to the lowest form of plant life, and which possess no chlorophyll ; they are therefore 
unable to form food material for themselves and obtain it from dead or living plants.

Fungi which obtain their food from dead plants are called saprophytes; these are not of great importance to the woodman. Those which live upon living plants are called parasites, and are of the greatest importance in forestry as they cause many bad, and sometimes fatal, diseases among forest trees.

Fungi are usually formed of many long filaments called hyphae, which together form a mass called the mycelium. This sometimes grows and spreads through living wood or bark, and is often only distinguishable with a microscope. Instead of flowers the reproductive organs are a special collection of cells, the whole being called a fructification, which produces large numbers of minute reproductive bodies called spores, which are, as it were, the seeds of the fungus. In the ordinary mushroom the part above ground, which we eat, is the fructification, the spores being borne on the gills. The mycelium of the fungus is below ground, and is often called the spawn by mushroom growers. The fructifications of most species usually appear for a few weeks only, chiefly about October, but in some species they are permanent, and are then often hard or woody. Warm damp weather is favourable to the spread of the fungi, while strong sunlight is unfavourable to them.

Some fungi attack sickly trees only, while others damage perfectly healthy ones. It is difficult sometimes to say whether a fungus is the cause of disease, or whether it is the result of previous debility in the tree.

Fungi are the cause of a great many diseases, especially in coniferous species, and with the larger planting of conifers which is taking place in Great Britain nowadays, disease is likely to spread, and woodmen must be on the look-out so as to take measures early.

The best general rules for prevention of disease are to grow species only on soils and situations really suitable to them, as they are then stronger and can withstand attack better;-to 


\section{WEEDS AND FUNGI}

plant good strong plants ; to form mixed woods so that trees liable to attack are isolated, especially mixing broad-leaved trees with conifers; to keep woods in a clean state by having timely thinnings; and to prevent wounds being formed in standing trees. Special measures which may be taken in certain cases are : Isolation of attacked plants by trenches; the cutting down and removal of diseased trees ; pruning and burning of attacked branches; and the spraying of diseased young plants with fungicides.

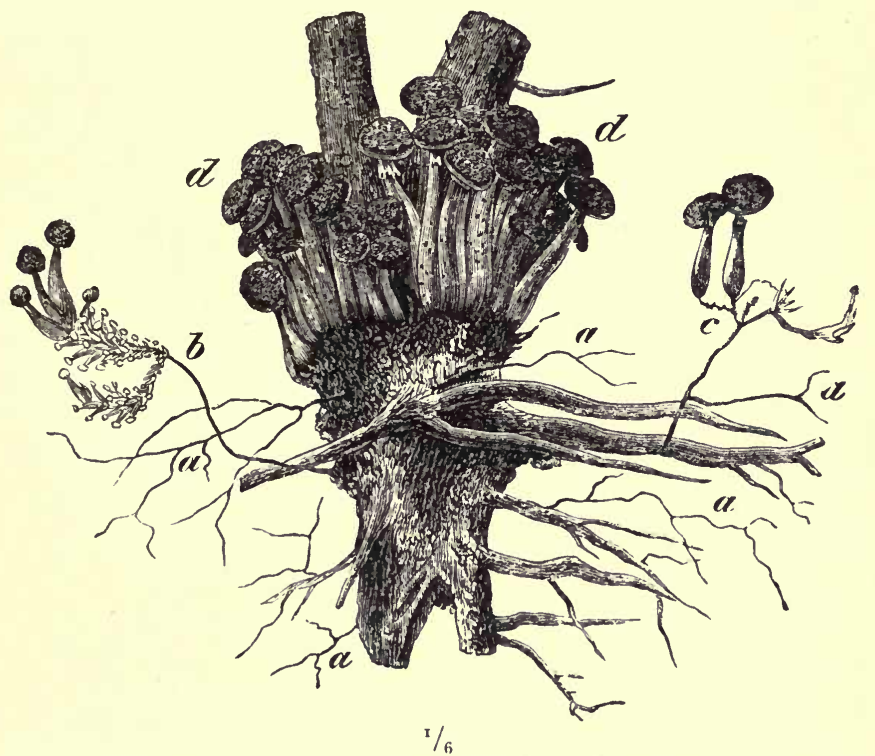

Fig. 9. Eight-year-old Scotch pine killed by $A$. mellea, Vahl. a Sterile rhizomorphic strands. $b$ and $c$ Fertile ditto; some of the fructifications are abortive. $d$ Fructifications springing from mycelia under the bark. (Reduced.)

\section{The Honey fungus (Armillarea mellea).}

This fungus is one of the most destructive to young conifer plantations. When the tree is attacked the needles become yellow and gradually dry up and fall, the base of the stem swells up, the bark peels off and turpentine exudes in 
quantities, often clogging together the soil round the tree. In the soil will be found black or brown root-like growths, termed rhizomorphs, which almost look like the leaf-stalks of a maidenhair fern; the thin, firm, white ribbon-like mycelium will be found between the wood and bark at the base of the tree.

The trees usually die very shortly after being attacked.

The fructifications or toadstools appear in numbers closely collected together round the base of the stem or on the surrounding ground in October, and are either of a bright yellow colour, or of a dirty brownish yellow, and vary in diameter from two to six inches.

When one plant has been attacked infection spreads to surrounding ones, as the rhizomorphs bore into the roots of neighbouring trees.

The fungus attacks nearly all conifers, of all ages, but especially trees from four to fifteen years old. It also attacks dead broad-leaved trees, and is often found on the stumps of felled oak and beech. Here it does no harm, but it spreads to conifers planted among these stumps, and is then destructive. It also attacks gate-posts and other dead timber placed in the ground. When the disease has appeared steps should be at once taken to prevent it spreading. All conifers attacked should be dug up with their roots, and these latter should be burnt.

The ground around the plant should be trenched and all rhizomorphs collected and burnt. Where the surrounding trees appear healthy a small trench, a foot deep, should be dug round the attacked plant, or group of plants, at some little distance away, so as to prevent the rhizomorphs spreading. It is not sufficient merely to pull up infected plants leaving most of their roots in the ground.

Any spot attacked and treated as above, should be visited periodically to see whether surrounding plants have been infected, and if so, the measures should be repeated. The 
blanks caused by the removal of the infected plants should be filled up with some broad-leaved species.

\section{The Red-rot root-fungus (Fomes annosus or Trametes radiciperda).}

This fungus is very destructive to conifers.

The infected trees appear very like those attacked by the honey fungus, they turn yellow and die in the same way. The mycelium, which will ke found between wood and bark, is however much more delicate and silky, and resembles tissue paper. The fructifications are not formed above the ground but on the roots, in masses like yellow or snow-white grapes; sometimes the mass is bracket-shaped.

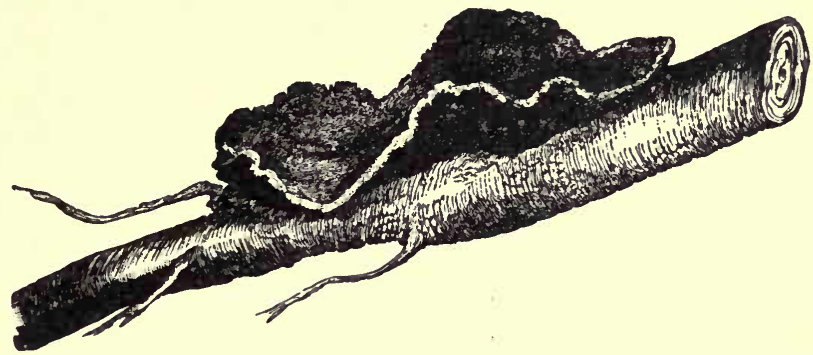

Fig. 10. Fructification of Fomes annosus, Fries., on a Scotch pine root. (Reduced.)

Other points of difference are that resin does not exude at the roots of the trees in large quantities, and that in the rotting wood are found black spots surrounded by soft white patches. The rotting wood is at first violet and then of a brownishyellow colour.

The disease spreads by the spores being carried about in the fur of mice, and by infection of sound roots by contact with those already attacked. Infected roots then rot, and the rot spreads upwards into the stem.

Isolation trenches are of little use with this disease, and the only remedial measure which can be taken is to dig up all 
attacked young plants with their roots. Old conifers are sometimes attacked; they must be cut and replaced with broad-leaved species.

Pine blister (Peridermium pini).

This disease is very common in pine woods in Great Britain, and trees attacked by it

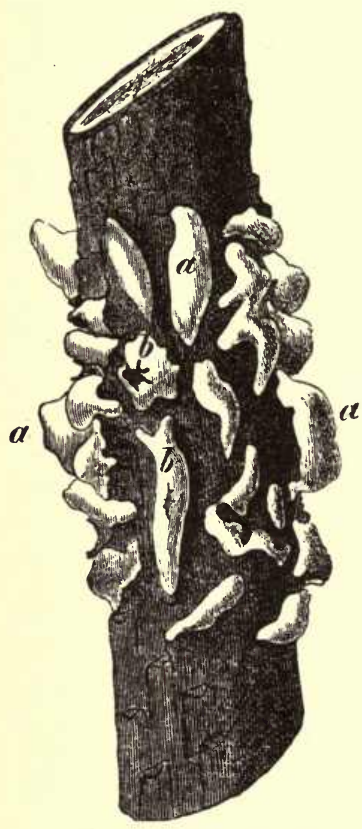

Fig. II. Peridermium pini, Wallr. (corticola), on a 5-year-old shoot of a mountain pine. The fructifications are closed $(a)$, or have already burst (b). (Natural size.) are often called 'foxy' trees. On infected pines orange-yellow tufts or fructifications are seen breaking through the bark in June. These liberate their spores and then appear white. The mycelium develops chiefly in bark and bast, but also in the timber, forming a canker which is covered with resin. The canker increases in size annually, working round the stem, and if it gets completely round, the portion of the stem above it dies. Pines of all ages are attacked, but the damage done is greatest in woods from fifteen to twenty years of age.

This disease is probably the most destructive one found in the British Isles with the exception of the larch canker.

The only measure which can be taken against it is to cut out all infected trees in the thinnings. These can be more easily distinguished in June when the fructifications are visible, and they should therefore be marked for felling then. Silver fir canker (Melampsorella Caryophyllacearum).

This fungus is fairly common wherever silver fir is grown. 
It causes the silver fir canker and 'witches'-broom'. The shoots attacked become brush-like and erect, and are of an entirely different appearance from the ordinary shoots. Such abnormal growths are called the witches'-broom. The mycelium grows in the bast, causing a swollen canker on which the bark is deeply cracked. Should the fungus attack a part where there is no living bud, a canker is formed but not the witches'-broom. The fructifications are orange-coloured, and appear on the under side of the leaves of the witches'-broom. They give out their spores in June, and the needles then die. The witches'-broom lives about sixteen years, and branches freely, somewhat resembling a bunch of mistletoe. It then dies, and only the canker remains.

Badly cankered trees may die outright, but more often they live on, the timber however being spoilt.

The best preventive measures are to prune off branches affected in June and July before the spores ripen, close to the stem, tarring the wounds. Cankered stems should be cut out in the thinnings.

\section{The larch canker (Dasyscypha calycina or Peziza Wilkommii).}

This fungus is without doubt the most destructive one found in British woods and has done an enormous amount of damage. It is found in almost every young larch wood in England, Scotland, and Wales, but fortunately it is less common in Ireland, especially in mixed woods.

The disease is recognized by the appearance of swellings on the stem and branches; the bark splits, turpentine flows out, and the wood is often exposed. In the cracks round the swelling, cup-shaped fructifications, about the size of a large pin's head, appear ; these are white outside and orange yellow within the cup. When the weather is damp these produce spores which infect other trees. As time goes on the canker increases in size, and becomes black and spoon-shaped. It gradually spreads round the stem, and may finally kill the 
tree. A great number of cankers may appear on the same tree. When the canker is high up, or when the tree is vigorous and is growing under favourable conditions, it will probably overcome the disease, or at any rate the tree will live on for years, although of course the timber is spoilt at

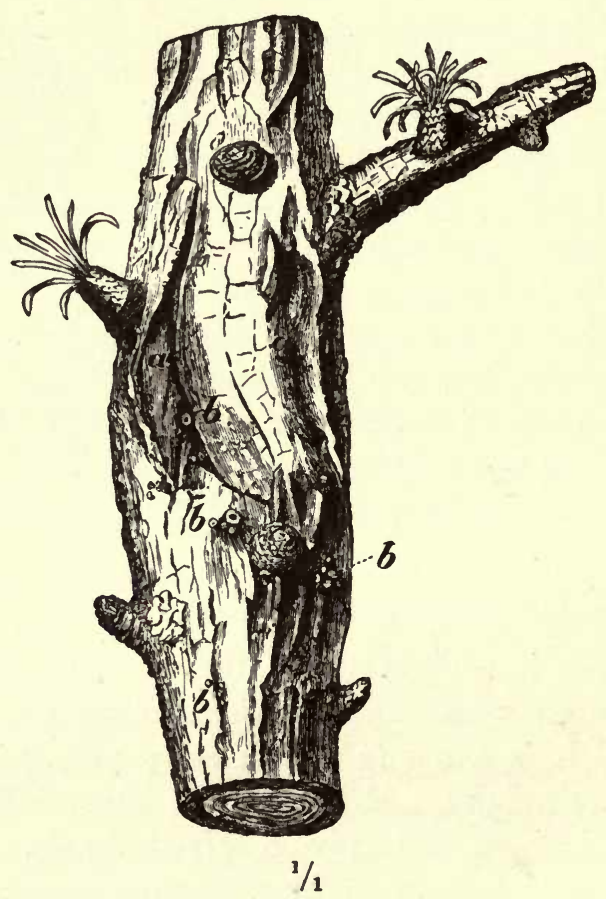

Fig. 12. Portion of Larch-stem attacked by Dasyscypha calycina, Fuckel. $a$ Cracks with outflow of resin. $\quad b$ Fructifications.

the canker. When young trees are attacked low down, and when the soil and climate are not suitable for larch, the tree will probably die before many years have passed. From a few infected trees the disease will spread throughout a young plantation, the spores germinating if they settle on a wound 
however small. Such wounds are always present on the younger parts of the stem, being caused by the bites of various insects, especially the larch aphis (Chermes laricis) and the larch miner moth (Coleophora laricella). Trees from ten to twenty years old suffer most: It has been found on Japanese larch, which is therefore not likely to be spared from this scourge, though it is not much attacked at present. The disease is worse in low-lying damp situations, and in frosty places than on high-lying land. It is usually worse in pure, densely-grown, larch woods than when the larch is scattered amongst other species. Bark which is over fifteen years old is usually not pierced by the fungus, so that, in a larch thirty years old and 45 feet high, the bottom 20 feet or so are safe, if not already cankered.

The chief protective measures to be taken against this disease are: To grow it in situations with a climate as near as possible that of its natural home, the Alps; that is on north aspects, and at high elevations; - to give it plenty of light and air by growing it singly, or in small groups, in woods consisting of species which grow slower than itself, so that its head will always be fully exposed; it does best when mixed with beech or as standards over coppice; to avoid growing it in large pure woods; - to grow it only on good well drained, but not dry soils; or on stony soils with plenty of humus; to avoid pruning green branches; and finally, in the thinnings to cut out all badly diseased trees.

The great object should be to induce vigorous growth of the larch. If this is obtained the disease will not get the upper hand, and the timber, even if cankered here and there, will still be of considerable value. If the larch gets into a bad state of health it soon gets covered with canker and its value is then much reduced. The older the trees can get before being attacked the longer will be the length of timber free from canker. 


\section{Polyporus sulphureus.}

This fungus causes red-rot in the timber of oak, sweet chestnut, poplars, willows, alder, birch, fruit trees, larch and

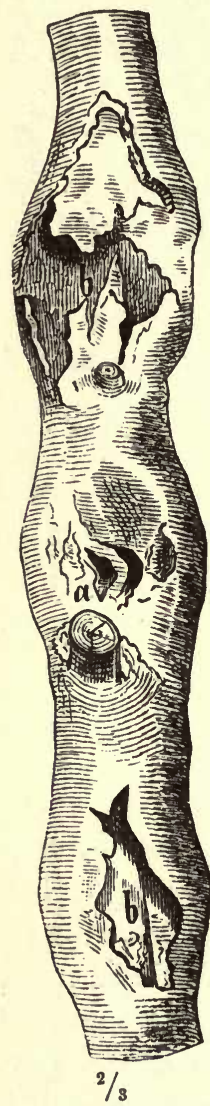

Fig. 13. Nectria ditissima, Tul., on a beech. $a$ Commencement of the disease, which has proceeded deeper into the wood at $b$. silver fir. Infection occurs through wounds on the branches and on the stems; the timber attacked becomes reddish brown, cracked and dry. The mycelium spreads through the cracks and forms large felted white sheets. The fructifications appear annually, and are very conspicuous, being large, bright yellow, smooth and cheeselike.

The only remedial measure is to cut down infected trees, care being taken not to damage other trees in removing them. Other forms of Polyporus, which often have bracketlike fructifications, cause various forms of rot in different species. Nectria ditissima. The canker of
broad-leaved trees.

This fungus is a very common one on beech, oak, ash, hornbeam, hazel, alder, lime, cherry, and apple, but is chiefly found on beech and ash. The part infected becomes cankered, and on careful examination in spring, dark red globular fructifications will be found on it. Trees of all ages are attacked, and the parts infected often become greatly malformed. Beech timber turns brown, and ash timber black, and, if badly attacked, the wood is only fit for fuel. The fungus is 
specially destructive in apple orchards. Cankered trees in a forest should be cut out in the thinnings, and great care should be taken not to wound standing trees while felling. With regard tc orchards, the Board of Agriculture leaflet No. 56 recommends the cutting off of young infected branches. On older branches the diseased part should be cut away, and the cut surface should be protected with a coat of gas tar. Grafts should not be taken from diseased trees.

\section{Beech seedling mildew. Phytophthora omnivora.}

This very destructive fungus attacks chiefly seedlings of beech, but also those of maple, ash, acacia, spruce, and Scotch pine. It may do considerable damage in natural regenerations, and may kill off whole beds of seedlings in nurseries. Damp warm years are favourable to the spread of the fungus, which may be carried about by wind and mice, or on the feet of men and horses. Infected seedlings turn black, and die from below upwards, during germination or immediately afterwards. The stem shrivels up and turns brown, and dark spots appear on the cotyledons, or young leaves. It spreads very rapidly.

The most effective measure against it is to spray the seedlings immediately the disease appears with Bordeaux mixture-Two pounds of sulphate of copper dissolved in ten gallons of water, with one pound of freshly burned lime added. All infected plants and dead leaves lying near by should be burnt. Those parts of the nursery where the disease has appeared should be used for transplants for a few years, and seed-beds should be formed in a new place. 


\section{CHAPTER $\mathrm{X}$}

\section{PROTECTION OF WOODS AGAINST FROST, DROUGHT, STORMS, AND FIRES}

THE measures to be taken against ordinary damage by frost have already been mentioned in Chapter II, and it remains only to deal with two peculiar effects of frost,-frostcrack and frost-lifting.

\section{FROST-CRACK}

Oak, beech, walnut, elm, ash, and sweet chestnut are most liable to frost-crack; it is however found in other species, though it is rare on conifers. Frost-cracks usually occur on the lower part of the stem and take the form of a long crack running up and down it. They usually are formed in late winter, when the sap is rising, if very cold weather prevails. The sapwood then contracts with the cold while the heartwood, being warm, does not; the result is a crack in the sapwood, which is often accompanied by a loud report like a pistol-shot. The crack is healed over by the growth of timber during the summer, but is usually opened out again the following winter. Pressure of the bark being thus relieved, the timber formed at the spot is laid on in thick layers, and a projecting rib of wood is formed called a frost-rib.

Frost-cracks are mostly found in open woods or in those which have been over-thinned after growing in a dense state. They do not affect the health of the tree, but spoil the most valuable part of the timber. The best protective measure is to keep woods in a properly dense state. Nothing can be done when once a crack has been formed, and affected trees should therefore be cut out in the thinnings. 


\section{FROST-LIFTING}

In February and March when there are frosts at night with a thaw in the day we find that young seedlings are often lifted out of the ground. This is due to the fact that the soil rises with the frost, and the plants are raised also; then when the thaw comes the soil sinks again, but the plants do not. When this has been repeated three or four times the plants fall over and lie on the surface, and soon die if long exposed. Nearly all species may be lifted, though this happens but rarely with seedlings, such as oak and sweet chestnut, which have long tap roots. Frost-lifting is not so bad on sandy soils as on stiffer ones.

To prevent damage in nurseries the spaces between the rows of seedlings should be covered with dead leaves. The nursery and recently-formed plantations should be visited daily in frosty weather, and all plants lifted should be at once replaced in the ground.

\section{DROUGHT}

Drought is seldom to be feared in Great Britain, at any rate not to such an extent as to damage established woods. A long spell of dry weather in summer will, however, cause a large proportion of failures in recently formed plantations and, unless care is taken, to nursery plants. It is seldom worth while to take measures against drought in the forest; failures in plantations must be filled up the following planting season.

In the nursery drought may be guarded against by covering spaces betwcen the plants with a good layer of humus or dead leaves, as this will keep the soil moist; by sticking branches of evergreen trees into the soil on the south side of beds of seedlings in such a way that these will shade the bed in the hottest part of the day; by covering beds with mats, lifted up on short supports, during the hottest hours; by 
hoeing the surface periodically to prevent it caking; or, if absolutely necessary, by watering the plants in the evening; if this is done the watering must be effective as it is useless to give a mere sprinkling.

\section{Winds AND STORMS}

There are three types of wind-dry east and north-east winds; sea-breezes carrying salt; and westerly or southwesterly gales-which do serious harm to woods in the British Isles; the woodman should take every possible precaution to reduce such damage to a minimum.

The chief measures to be taken against dry east winds and against sea-breezes have been indicated in Chapter II, the main object being to form an efficient wind-break some twelve to fifteen years in advance of the regeneration of the woods behind them. In existing young woods, where it is too late to form a shelter belt of evergreen trees, every endeavour should be made to keep the east and north-east sides in as thick a condition as possible by reducing thinnings to a minimum along a belt 40 to 50 feet wide, and by carefully preserving all undergrowth which springs up.

East winds prevail in spring and dry up the soil, blow dead leaves away from ridges and slopes and thus prevent the formation of humus, hinder the formation of dew, injure the foliage and flowers, and if planting is going on they dry up the roots unless precautions are taken. Together with other winds they spread the spores of fungi. Broad-leaved trees suffer more than conifers from such winds; while seedlings, young transplants, and young coppice shoots suffer more than older trees.

Storms are more serious and are more difficult to deal with, as the power of the woodman is limited, and he cannot hope to overcome successfully the force of nature. Nevertheless a good deal can be done to reduce damage. Storms either break trees or uproot them, and if a large quantity of 
timber is thrown in a gale the market is glutted, and the price obtainable for the timber is small; this adds considerably to the loss sustained. In addition, large blanks may be made in the woods; and large trees may fall on young growth and injure it. In coniferous woods, owing to the large amount of dead timber lying about, insects may increase rapidly, and thus cause damage to other standing woods. The chief damage is, however, done by the stunting effect of wind, as trees grown in exposed places will be short and misshapen and of small volume.

Conifers and evergreen trees suffer from storms more than broad-leaved and deciduous trees, while shallow-rooted trees are more easily uprooted than those with deep roots. Ash, sycamore, Norway maple, alder, lime, and oaks are fairly storm firm. Trees grown always in the open resist storms better than those which have grown up in a dense wood, and which have then been opened out.

The following protective measures should be carefully carried out, as the fight against storms must be begun when the woods are planted, and must be continued throughout their life.

Measures to be taken while forming woods.

I. In places where storms are specially bad, plant broadleaved species in preference to conifers.

2. Plant the trees on the exposed edge at distances rather far apart, at least 6 feet, so as to encourage them to grow sturdy.

3. Mix deep-rooted species with shallow-rooted ones; thus, mix beech, sycamore, or Scotch pine, with spruce. In spruce woods five or six rows of a deep-rooted species may be planted across the storm direction every one hundred and fifty yards.

4. Form protective belts, if none already exist, along all exposed sides and along roads. 
5. Form wide rides through the woods. The trees along them will grow up storm firm, and will afterwards protect woods behind them. The main rides should be formed parallel to the storm direction so that the wind blows harmlessly down them. Cross rides can be formed between the main rides. These rides should be formed when the woods are planted; if they are afterwards cut through existing woods there is a chance of wind doing damage.

\section{Measures to be taken during tending of woods.}

I. Make early, frequent, and moderate thinnings. Heavy thinnings in densely growing woods must be avoided.

2. Keep the woods dense along a 50 feet wide belt on exposed sides, but allow the outside row of trees to branch low down, by never allowing them to become crowded.

\section{Measures to be taken during the felling of woods.}

I. All places badly exposed, such as hill-tops, should be regenerated under the selection method, so that the area is never blank.

2. Fellings in any wood should be commenced on the side furthest away from the storm direction; in Great Britain they should therefore usually commence on the north-east side of the woods, and gradually proceed towards the south-west. By doing this a cutting will never expose a middle-aged or mature wood to storms, while the young plantation, which is not apt to suffer much in any case, grows up behind the shelter of woods still uncut. This measure is one of the most effective, and should never be neglected. To ensure its being done it is even worth while to cut a middle-aged crop before a mature one, if this happens to be necessary.

If two parts of a wood are separated by a broad ride or road, along which the trees are storm firm, each part may be treated as a separate wood, and cuttings may be made in both parts. 
3. Felling areas should take the form of long narrow strips instead of large square blocks.

4. No standards of shallow-rooted species should be left standing, as they are almost sure to be blown down.

5. When felling woods, the strip of weather-beaten trees along the exposed edge, to a width of 50 or 60 feet, should not be felled, but should be left standing to protect the new crop. These trees are usually misshapen and stunted, and it is a mistake to cut them and replant, as the new crop will be no better than the existing one.

Should windfall occur on any large scale, especially in coniferous woods, every endeavour should be made to sell the fallen timber as soon as possible, as if left in the forest the logs act as breeding-grounds for numerous species of insects. If a sale cannot be effected at once all conifers should be stripped of bark.

\section{FIRES}

Fires are caused chiefly by carelessness, but occasionally on purpose by persons having a grudge against the owner or woodman. The chief causes of forest fires are: carelessness in throwing away cigarette ends or lighted matches, carelessness on the part of workmen in the woods in leaving fires alight on leaving work; and by sparks from locomotive engines.

Fires do harm by burning young trees, and by scorching the bark of older trees. They also burn dead leaves and dry humus lying on the ground, thus rendering the soil poor. On an area through which fire has passed there is an additional risk of insects, especially in coniferous woods.

Danger from fire is greatest in young pine woods, owing to the early drying up of the lower branches; spruce also burns easily owing to the resinous needles. Amongst broad-leaved trees, rough-barked ones such as oak and elm will stand fires better than smooth-barked trees, such as beech and ash. 
Young plantations are most exposed to damage, as weeds are plentiful, and when these have been killed out in the thicket stage, the danger is still great as the lower branches are dry. After the woods have passed the age of thirty years the danger of damage rapidly decreases.

Taking all things into consideration the danger of fire is greatest in young pine plantations, growing on sandy soil with a good deal of heather. The most dangerous season is March, when dry winds prevail, and bracken or heather is still dry. August is also a dangerous month if rainfall is deficient.

Under the Railway Fires Act 1905, the Railway Companies are liable for damage done by fire to the extent of $£ \mathrm{IOO}$, but this will often not cover the injury done.

The following measures may be taken to reduce the danger of fire and to limit the area likely to be burnt.

I. Strips, 25 to 35 feet broad, of broad-leaved trees may be planted through coniferous woods. Where the risk of fire is very great these strips may be kept clear of weeds.

2. In young pine woods all inflammable material such as heather, fern, \&c., may be burnt early in the season, on either side of railways and much-frequented roads or rides. Such burnt fire lines limit the area burnt, and form lines of defence should a fire occur. In preparing them a guide line 6 feet broad is first cut on the side furthest from the road or ride, and then the weeds on the line are burnt in situ, care being taken to have sufficient men on the spot to prevent the fire getting out of hand, and to stop burning should a heavy wind get up. Each man should have a branch of an evergreen tree ready, with which he can beat out any fire which crosses the guide line. One or two men should follow the firing gang, and should see that all smouldering embers are extinguished.

Fire lines should be 50 feet broad along railway lines, but 20 to 30 feet is usually sufficient along roads or rides.

3. Belts of birch or false acacia should be planted along railways, on the forest side of the burnt fire line. The non- 
inflammable foliage of these species intercepts sparks which are blown over the fire-line.

Conifers planted close to a railway will kill out all grass and weeds, but may, when in the thicket stage, catch fire themselves.

4. A good system of roads and rides through the forest will greatly help in limiting a fire to one block.

5. Workmen should be cautioned at the commencement of every fire season against carelessness in leaving fires, and regarding smoking.

6. As it is of great importance to commence extinguishing a fire as soon as possible after it starts, a sharp look out should be kept over the woods in dry weather by all woodmen. If the lodges are on high land overlooking the woods, the woodman can easily take a look round, periodically, and especially just before going to bed. If the lodge is surrounded closely by woods, a long ladder standing against a tall tree will enable the woodman to climb the tree easily, and he can then see to a distance.

7. On bank holidays in dry weather, in woods liable to be overrun with holiday makers, it is advisable to have all the staff patrolling the woods to warn people against making fires, and to be ready to concentrate on any fire which arises. This measure is carried out in parts of the Highmeadow woods with satisfactory results. The men can be given a holiday on some other day to make up for their own lost day.

8. If all lodges in large woods are linked together by telephone, rapid concentration on a fire is greatly facilitated.

Should a fire break out, as many men as are available should be at once sent off to the place, and should take with them bill-hooks, axes, rakes, large flat shovels, and besoms, or branches of evergreen trees, with which to beat out the fire.

If the work is likely to be a long one, the head woodman should arrange for a supply of drinking water to be brought to 


\section{I46 PROTECTION OF WOODS AGAINST FROST,}

the men, as there is no thirstier work than this. The fire should be attacked on both sides by beating it out, or by sweeping the burning material into the already burnt area. It is seldom possible to attack it from the front owing to the smoke and heat, but attack from the sides will gradually narrow the fire. If there is no wind this work will usually be successful, the time taken depending on the number of men available.

If the fire is in the crowns of trees in the thicket stage, beating is usually useless. In this case, and wherever beating proves of no avail, counter-firing must be carried out, sacrificing a portion of the woods in order to save the rest. A cleared ride, road, fire-line, or stream some little way in advance of the fire is chosen as a point of attack, and all the men available are concentrated on this line. When the fire is some two chains away, each man lights another fire 3 or 4 yards from the side of the line. This he watches, and takes care to prevent it or any sparks crossing the line. When the main fire approaches, a draught will be caused towards it, the small fires will be drawn inwards, and will meet the main fire, when the whole will go out for want of fuel. While this is in progress, every care must be taken to extinguish at once any fire which may manage to cross the line. In many cases where the nearest cleared ride is some distance away from the fire, it is possible to clear a line a short distance ahead, by cutting the weeds, and by brushing away dead leaves, and to counter-fire from the swept line. If this can be done it may be possible to save much woodland which would otherwise have to be sacrificed.

Counter-firing is difficult to carry out, and is risky, and must only be undertaken in extreme cases, where it is obviously impossible to put out the fire by beating. A fire which burnt some 250 acres of heath land, and which endangered several hundreds of acres of twelve-year-old Scotch pine plantations in Windsor Forest, was extinguished in this way in 1907. 
When the fire is out the area should be gone over carefully; and all smouldering wood should be extinguished by heaping earth upon it. Care must be taken that it does not start afresh if a wind springs up.

Young coniferous woods much injured by fire should usually be felled and replanted, while young broad-leaved trees may be left a year or two to see whether they recover ; if not they will often throw up coppice shoots if cut back. 


\section{CHAPTER XI}

\section{SYLVICULTURAL NOTES ON THE BROAD- LEAVED TREES}

Acacia, False Acacia or Locust-tree (Robinia pseudacacia).

A native of North America, introduced into Great Britain in 1638 . It requires a good deal of warmth, and should be grown only in situations with a mild climate, and is more suitable for the south of England than further north. South aspects are best. It is frost-tender, and requires shelter when young. It is highly light-demanding. Deep, dry, light, and moderately rich soil suits it best, but it grows fairly well on poor sandy soils.

It produces good seed, which should be kept in the pod until it is sown; it coppices well and throws up numerous suckers. It can be grown in high forest mixed with pines in groups, and is useful as a belt along railway lines running through pine woods where there is danger of fire. It does well as standards-over-coppice, and also as coppice, if not shaded by standards. It is a very ornamental tree, and can be grown in parks and along the edges of plantations.

It does not suffer much from attacks of insects or fungi, but is often damaged by rabbits. It is ripe for the axe at about forty to sixty years in high forest, and at from ten to twentyfive years in coppice, small sizes being useful for hoops for casks, and for hop-poles.

Alder (Alnus glutinosa).

A native of Great Britain and of Europe, it is found up to an elevation of $\mathrm{J}, 600$ feet in Scotland. It is hardy against frost, but cannot stand drought. Any aspect will suit it. It is 
light-demanding, but will bear a fairly heavy shade when young or as coppice. It requires a wet soil, but does not do in stagnant water. It does well on fairly deep sandy loams; cold clays and dry sands are unsuitable. It is a good tree for planting on low-lying wet places and along streams, and it can often be grown with profit as coppice under ash or poplar standards in wet places. It is a quick grower. It produces plenty of seed and coppices well; it also sends up many suckers. It is not often grown in high forest, but when so grown reaches maturity at about sixty years. In coppice it can be cut at any age up to forty years. It does not suffer to any great extent from insects or fungi. The chief dangers to which it is exposed are frost-lifting shortly after being planted, and drought.

\section{The White Alder (Alnus incana).}

Can bear a considerable amount of shade, and does well on shallow poor soils, and even on dry ground. It may be substituted for the common alder under these conditions. It is a useful tree on an exposed spot as a shelter tree for a more valuable species, which can be planted between the lines of alder when the latter is large enough to give the required shelter. It is also useful for covering spoil heaps from stone quarries and other unsightly banks of poor soil.

Ash (Fraxinus excelsior).

A native of Great Britain and of Europe, it is found up to an elevation of I,350 feet in Yorkshire. It does not require much heat, but is tender against late frosts, and a light shelter is useful when young. It does best in moist situations on north and east aspects. It is storm firm. It is very lightdemanding in later life, but seedlings will stand a heavy shade for a few years, and as coppice it stands light shade. It prefers a fresh, deep, light, loamy soil, with some lime, and plenty of humus, and grows well on the sides of ravines.

It produces good crops of seed about every second year 
after forty years of age, and is easily reproduced naturally. It forms good shoots when coppiced.

Ash is best grown in high forest scattered here and there singly, or in small groups, in woods of other broad-leaved species, especially beech. It can be grown as standards-overcoppice, or as coppice under a light shade. Existing young pure woods should be underplanted.

It is a fast grower, and forms a straight stem which forks at about half its height. The roots are extensive and deepgrowing. In the thinnings ash should be given plenty of space, and other species should never be allowed to top it. It is ripe for cutting at from sixty to seventy years, and is a very profitable tree, being saleable at all sizes. It does not suffer much from disease, though it turns black-hearted on unsuitable soils and is injured by a fungus (Nectria ditissima). The shoots are sometimes stunted by a moth (Prays curtisella). The ash bark-beetle kills weakly trees.

White Ash (Fraxinus americana) has much the same characteristics as the ash, but it stands frost better and grows well on dry sandy soils which are not good enough for common ash. Its seed germinates in the first year after ripening.

Beech (Fagus sylvatica).

A native of England and of Europe, it is found up to an elevation of $I, 200$ feet in Derbyshire. It is tender against late frosts, but otherwise it is hardy. It grows best on north or east aspects, and does well near the sea; it withstands an exposed situation fairly well. It does best on a fairly deep, porous, fresh, and fertile soil, especially where there is a good deal of lime. It is essentially the tree for marls and chalky soils, but does well on moist sandy soils or on moderately stiff clayey soils with lime. It is a great shade-bearer, and for the first few years, when it is very subject to damage by frost or by hot sun, it may be considered as shade-demanding. It produces good seed from sixty years of 


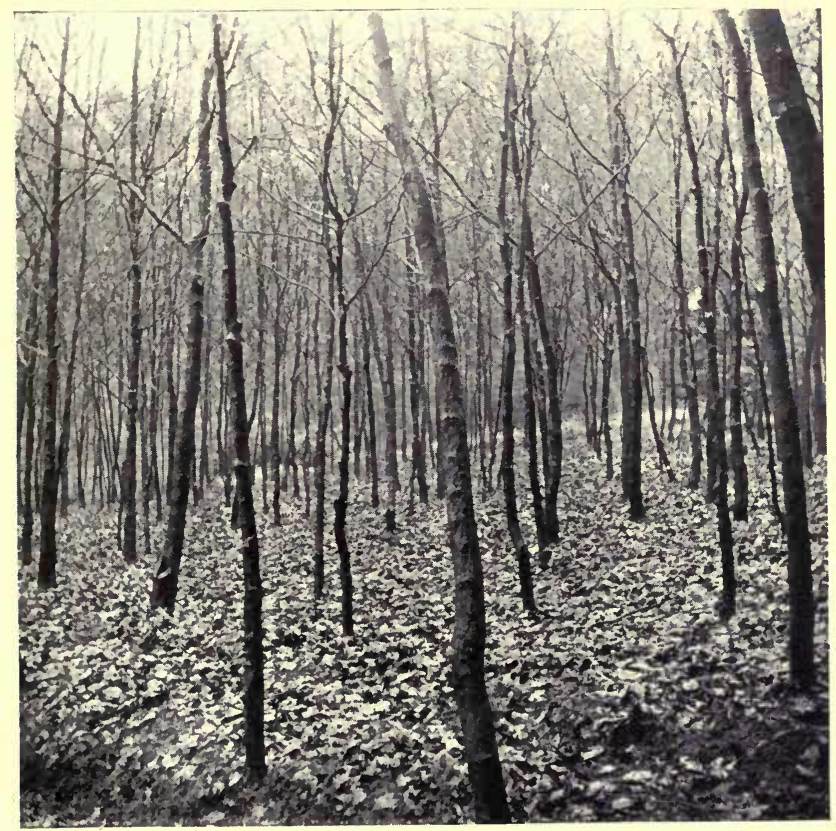

Beech planted I89I at 4 feet by 4 feet. Height 35 feet, girth up to 16 inches. The ground is covered with dead leaves. Coopers Hill. January, I9ı. 

age, but usually only at intervals of from five to nine years. It coppices badly, and the stools only last three or four rotations.

Beech is best grown as high forest in pure woods on rotations from 80 to $\mathbf{I} 20$ years, but first-class timber of ash, oak, larch, \&c., can be produced by introducing these trees into the beech woods, either singly or in small groups, and it is chiefly as a nurse to the valuable light-demanders that beech will be grown in Great Britain. It is the best tree for underplanting open woods of light-demanding species. It is unsuitable for standards-over-coppice, and is not very good as coppice except as a soil improver. It must be grown densely, or the stems will not get naturally pruned; thinnings must be lightly conducted. It is a slow grower at first, but after twenty to thirty years the rate of growth increases. Beech woods are very suited to natural regeneration, especially when the soil contains lime. An aphis (Coccus fagi) does considerable damage, otherwise it does not suffer much from insects or fungi, though it is attacked by a good many species. The bark of trees suddenly exposed to the sun is very often blistered.

\section{Birch (Betula alba).}

A native of Great Britain and Europe, and is found up to an elevation of 2,500 feet in Scotland. It is very hardy and does not suffer from frost. It does well on any aspect. It is highly light-demanding. It is very accommodating as to soil, and can be grown on almost any kind of soil and situation. It produces large quantities of seed, is easily regenerated naturally, and is apt to come up wherever there is clear ground, and is often a troublesome weed in plantations. Coppice shoots are usually weak, and the stools die after two or three rotations. It is not a good tree for pure woods as the soil deteriorates under it, but it is found growing alone where the soil is too poor for other species. It should be grown singly or ingroups in woods of other broad-leaved species. It should not be mixed with conifers as it injures them by the 
whip-like action of its branches. It is suitable for standardsover-coppice, and is very useful as a shelter wood over a tender species, and it is chiefly for this purpose that it is planted. It is a quick grower, and is usually cut at from forty to sixty years of age. It does not suffer much from insects or fungi.

\section{Cherry or Gean (Prumus cerasus).}

A native of Europe. It is found here and there in most English woods. It is fairly hardy against frost and will grow on any aspect. It is a light-demander. It will grow on almost any soil, but does best where it is not too wet and where there is some lime. It is propagated by sowing the stones shortly after collection in July. It coppices well, and also sends out suckers. It usually is grown singly here and there in high forest, and often forms part of the coppice in coppice-withstandards where there is not too much shade. It will grow to a height of 60 or 70 feet in close canopy with other trees, and reaches maturity at fifty or sixty years. The timber takes a fine polish and is valuable for furniture.

It is only of small importance in British woods, but is a very ornamental tree along the edges of plantations.

\section{The English Elm (Ulmus campestris).}

A native of Central and South Europe, it was introduced into Great Britain by the Romans. It is found up to an elevation of $I, 500$ feet in Derbyshire. It requires a mild climate, but is fairly hardy against frost. It does best on flat land, and south aspects are preferable in hilly places. It is a light-demander, but will bear a light shade better than oak or ash. It requires a deep, porous, moist, and fertile soil, and does best in low lands and valleys. It seldom produces fertile seed in England, and is best propagated from suckers. Where there are a few elms in a hedge, suckers will be found coming up plentifully in the neighbouring field, and a strip of land can be fenced off and used as a nursery. Elm is chiefly found in hedgerows and in parks, but it could be grown as a forest tree in small 
groups mixed with other broad-leaved trees. It should not be grown in pure woods. It must be given plenty of space for its crown from middle age upwards. It is a rapid grower, and attains a good height. It ordinarily reaches maturity at about eighty years.

Elm suffers to a certain extent from insects and fungi. The bark-beetle (Scolytus Geoffroyi) does much damage to weakly trees. The branches of large elms are very apt to fall off and are often dangerous in avenues and parks.

\section{Wych-elm (Ulmus montana).}

A native of Great Britain and Europe, and is found up to an elevation of $\mathrm{I}, 300$ feet in Yorkshire. It does better in Scotland than the common elm, and is more a tree for hilly land than the latter. It does well in ravines and near the sides of streams. It is hardier than the common elm and is more accommodating as to soil and situation. It does fairly well on stiff loams, but does not thrive on sand. It produces large quantities of seed and also good stool shoots. It should be grown, like common elm, in groups here and there in woods of other broad-leaved trees. In other respects its characteristics are much the same as those of the common elm.

Hazel (Corylus avellana).

A native of Great Britain, Europe, and Asia Minor. It is found up to an elevation of $I, 900$ feet in Scotland. It is frosthardy and will succeed on any aspect. It is a moderate shadebearer. It prefers a fresh, porous soil of moderate depth, but will grow on almost any soil provided it is not marshy. It seeds well, and also coppices easily. It can be layered or 'plashed', and this method of reproducing it is useful for filling up blanks in existing coppices. It is chiefly grown as coppice under oak standards, and is cut on rotations of from seven to twenty-five years. Its value has greatly declined recently, and new coppices of hazel are hardly required, except possibly in woods kept mainly for sport. 


\section{Holly (Ilex aquifolium).}

A native of Central Europe. It is hardy, but does best when sheltered. It is not particular as to aspect. It is a great shade-bearer. It does best on a light, dry soil with plenty of humus, and prefers soil containing lime. It "seeds well and produces good coppice shoots. It can hardly be regarded as a useful forest tree and is usually grown for ornament. It is, however, a very good plant for evergreen hedges. Seeds should be treated like those of ash, as they do not germinate till the second spring after ripening.

Hornbeam (Carpinus betulus).

A native of Great Britain and Central Europe, it is generally a tree of low lands and low hills. It is hardy, and will do better than other species in cold, damp situations; it prefers north and east aspects. It is a good shade-bearer, but not sogood as beech. It does best on a loose, fresh, rich, and fairly deep soil, but it will succeed on soils of most descriptions and is useful on a heavy clay. It seeds and coppices well. It can be grown as a pure wood either as high forest or as coppice, but is hardly valuable enough to be grown on a large scale. Its chief use in Great Britain is as a substitute for beech for mixing with or underplanting woods of light-demanding species on heavy clays or in very frosty places. It also makes an excellent hedge. It can be cut at any age up to 100 years in high forest, and at from fifteen to thirty-five years as coppice. It reaches a height of 50 to 60 feet. It suffers but little from insects and fungi.

Horse-chestnut (Aesculus hippocastanum).

A native of Greece and parts of Asia. It is a hardy tree, and grows on any aspect, but its branches are often broken by wind in exposed situations. It will bear a light shade. It does best on a good, rich, loamy, fairly dry soil. It is used as an ornamental tree, and is not valuable enough to be grown in woods, its timber being soft and not durable; it might, however, become valuable for the manufacture of wood-pulp. It 


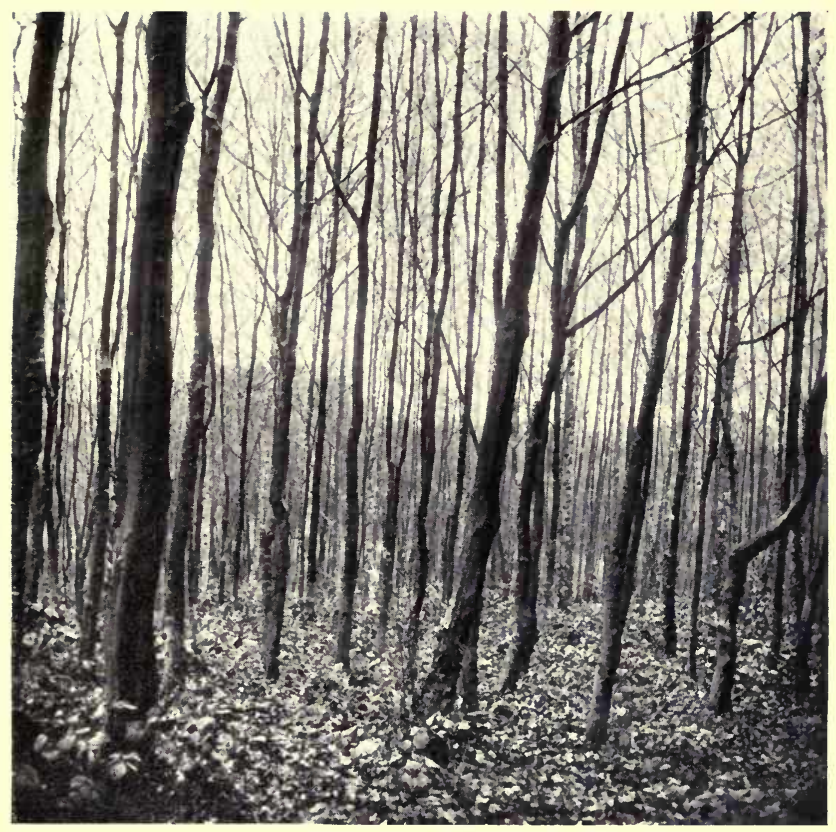

Hornbeam planted I89I at 4 feet by 4 feet. Height 35 feet, girth up to 16 inches. In the background is pure birch. Coopers Hill. January, I9I0. 

is a rapid grower. Its chief enemy is a fungus (Nectria cinnabarina), which may be recognized by the bright red fructifications which break out on the branches.

\section{Laburnum (Cytisus laburnum).}

A native of Central and South Europe, and has long been cultivated in Great Britain. It is chiefly of use as an ornament in parks and gardens and on the edges of plantations. It will grow on most soils, but to reach a large size it requires a deep, loamy, and fairly dry soil and a sheltered situation. The timber is valuable for cabinet-making, and fetches a good price if large.

\section{Lime-tree or Linden (Tilia europaea).}

There are three varieties of the lime-tree: the large-leaved lime (Tilia grandifolia), the small-leaved lime (Tilia parvifolia), and the intermediate form (Tilia intermedia). The lime-tree is a native of Central and South Europe and has long been grown in England. It is a tree of the plains, and does not do well at high elevations. It is frost-hardy; it stands half-way between the light-demanders and the shade-bearers; that is to say, it will bear a light shade in favourable situations. It does best on a fresh, fertile soil, the large-leaved variety being more exacting than the small-leaved tree in this respect. The latter should therefore be preferred on poorer soils. It can be grown from seed, or from layers; it coppices well, and produces good straight shoots. The timber is not good enough to warrant the growth of this tree in woods, and it is chiefly used as an ornamental tree in parks, and for avenues. It is, however, useful in coppice woods when there are many rabbits, as it is not touched by them owing to its stringy bark.

\section{Monntain Ash (Pyrus Aucuparia).}

A native of Great Britain, and the hardiest of all our trees ; it will grow at high elevations on all aspects and on most soils. It bears some shade. Its timber is good for cartmaking and for agricultural implements owing to its toughness, 
but it can hardly be regarded as a forest tree. It is useful as an ornamental tree along roads and rides, and sylviculturally it may be useful as a nurse to tender trees in small plantations, where larch and birch would grow too quickly and would suppress the others.

The English or Pedunculate Oak (Quercus pedunculata).

A native of Great Britain and Europe, it is found to an elevation of $I, 500$ feet in England. It requires warmth, and does better on southern than northern aspects. It suffers from late frost, but it comes into leaf so late that it usually escapes damage. It is highly light-demanding and should have its head free throughout life. It is very storm-firm. It requires a deep, fresh, fertile soil to do really well, but it will grow on stiff clays and also on moist, sandy soils, and limestones. It produces seed heavily every three or four years, and also throws up good coppice shoots, the stools living for many rotations. Oak is not suitable for pure woods, but it may be grown pure up to the fortieth year, when it should be underplanted with beech. It can also be planted in groups surrounded by other species, of which beech is the best; in fact first-class oak timber can hardly be produced without an admixture of beech. Oak of a very fair quality can be grown as standards-over-coppice, though in this case the timber is short, unless the standards are left in groups. It used to be largely grown as coppice when bark was of more value than it is now. It is a moderately fast grower and has a deep root-system. It has a decided tendency to throw out large branches, so the thinnings should be light in character till the fiftieth or sixtieth year, and then they should gradually be made more heavy so as to isolate the crowns. Oak matures at about 150 years. A large number of insects live on this tree, but on the whole damage is not serious. The oak-leaf-roller moth defoliates whole woods, but the trees recover with the second flush of leaves. Canker is caused by the fungus Nectria ditissima. 


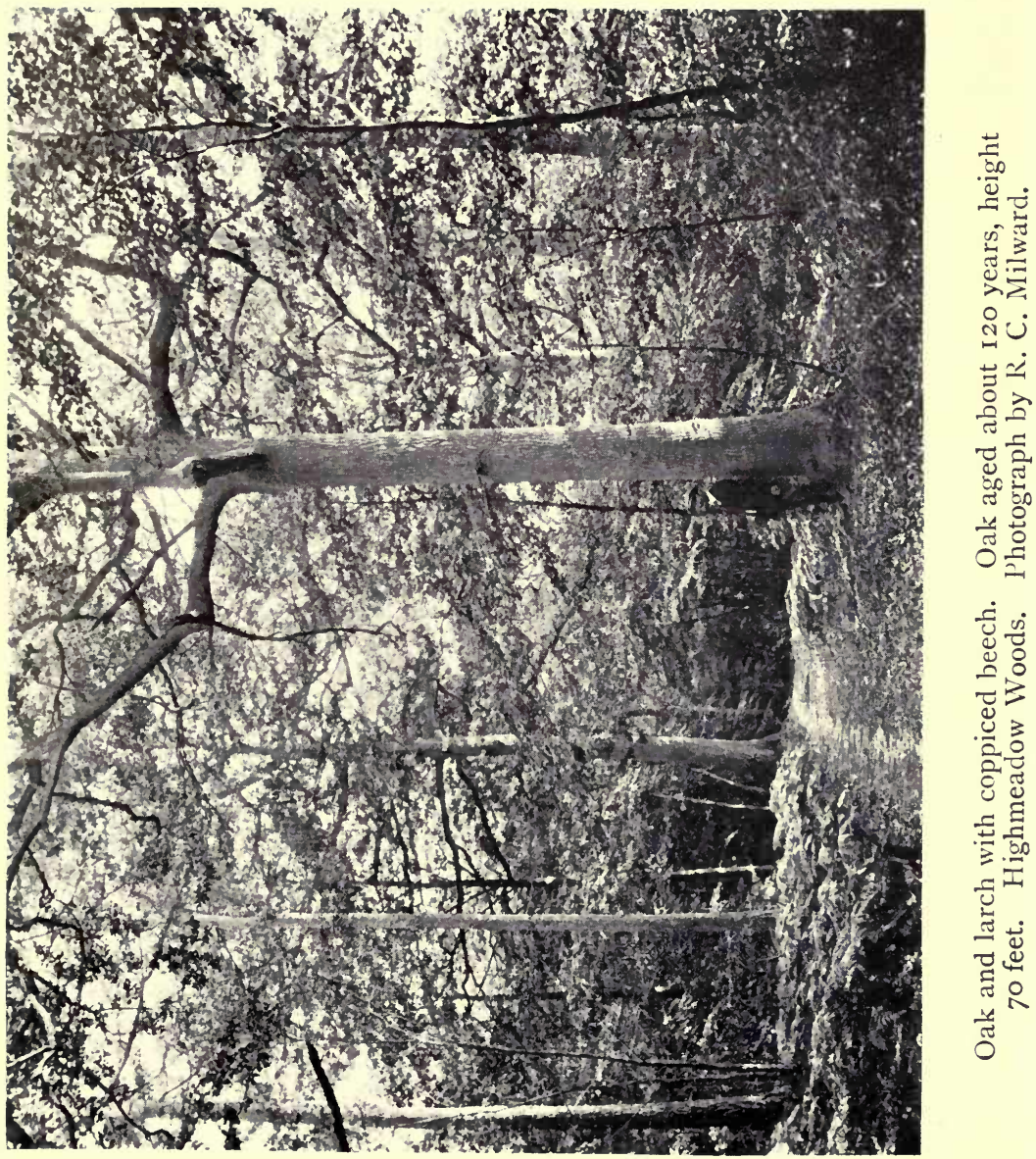



The Sessile or Durmast Oak (Quercus sessiliflora) has much the same characteristics as the English oak; it is the more common species in Wales. It is on the whole a hardier tree. and is content with poorer soil than is the English oak; it should be preferred at high elevations and on the poorer and drier soils. It does not tend to produce horizontal branches, and it is therefore easier to obtain straight clean timber from woods of sessile oak.

Occasionally when an oak has been felled the timber is found to be brown in colour. This is 'Brown Oak', which is worth from six to ten shillings per cubic foot.

\section{The Turkey Oak (Quercus Cerris).}

A native of South Europe, it was introduced into Great Britain in 1735 . It does best on southern aspects and sheltered positions, and prefers dry loamy soils; limy loams or clayey limes suit it well. It grows quicker than the English oak, but it will never be a valuable forest-tree as its timber is not so durable as that of the English or sessile oak, and is very heavy. It is used for furniture and cabinetmaking. It forms a fine ornamental tree in a park, but it gets injured if much exposed to wind.

\section{Plane.}

There are three species often planted in avenues and parks in large towns: the Oriental plane (Platanus orientalis); the Western plane (Platanus occidentalis); and the London plane (Platanus acerifolia), a variety of the Oriental plane. None of these are forest-trees, but they are very ornamental and flourish in towns where other trees are killed by the smoke and dirt, and they are chiefly used for town planting. They do best on deep, light, moist soil and in sheltered positions. They can be grown from seed, but they are best propagated from layers or cuttings. The timber is of good quality, and is used for the framework for veneering. 


\section{Poplar.}

The following species are often grown or are found in British woods :-

The Black poplar (Populus nigra).

The Black Italian poplar (Populus canadensis).

The Lombardy poplar (Populus pyramidalis).

The White poplar (Populus alba).

The Grey poplar (Populus canescens).

The Aspen (Populus tremula).

Of these the Black and the Black Italian poplars are the most profitable timber trees. They grow rapidly, and will give large-sized timber at from forty to fifty years of age. They should be planted on a good, deep, moist soil in sheltered positions, but large trees will also be obtained on poor soils if situated on a sloping bank where there is plenty of moisture. The Black Italian is the more accommodating of the two as to soil.

The Lombardy poplar is not a forest-tree, and is chiefly used for providing shelter, as when planted closely in a line it soon forms a tall hedge.

The White and Grey poplars provide timber very suitable for match-making or any other industry requiring a light and soft wood. They thrive best in moist sandy loams and in sheltered situations, but the grey poplar is very accommodating and will grow to a large size on many different soils, while the white poplar does well on clays. Both these trees are best raised from suckers.

The Aspen is very hardy, and will grow in most soils and situations; it comes up naturally in many woods, and often becomes a troublesome weed in plantations of more valuable species owing to the great number of suckers it produces.

As a whole the poplars are hardy trees and light-demanders; they prefer moist soils and situations sheltered from wind, and are useful for planting up damp hollows and along the 
sides of streams. They are usually propagated from cuttings or from suckers, and are rapid growers. 'The leaves of poplars are much eaten by the larvae of many species of moths, but no great amount of damage is done. The timber is bored by the goat-moth caterpillar. The small poplar longicorn beetle (Saperda populnea) does a considerable amount of damage to young plants. Fungi do no serious damage.

\section{Sweet or Spanish Chestmut (Castanea vesca).}

A native of Southern Europe, it was probably introduced into Great Britain by the Romans. It is a tree which should be restricted to warm situations and low elevations, southern or western aspects being best, though it does well on northern aspects in the south of England. It is tender against frost, and cannot withstand severe winter cold. It is a lightdemanding tree after early youth, but not so much so as the oak. It stands a fair amount of shade till about twenty years of age, and also when grown as coppice. It is storm-firm. It does best on a deep, porous, fresh, and fertile soil, but can grow on rather dry soils if deep; it does not like wet or limy soils, but will produce fair timber of small size on clays.

It seldom produces good seed except in the south of England, but it sends up very good stool shoots even from old stools, and it is therefore a very good tree for coppices and underwoods. It also produces suckers. It can be grown as high forest, standards-over-coppice, and especially as coppice. It should not be grown as a pure wood as high forest except on short rotations and on good soil, but pure coppices are allowable as, with a short rotation, it keeps up the fertility of the soil. As high forest it is best grown in groups mixed with beech and oak, while a mixture of larch and chestnut is also good on a fertile soil. It is a rapid grower and attains a large size, but large timber is usually much shaken, and it is therefore best to cut it at an age of forty to fifty years. As coppice it pays well on a rotation of 
fifteen to twenty years where there is a demand for hop-poles, or for split chestnut fencing material. It deserves more attention as an underwood tree than it has yet received in England. With regard to thinnings, these should be made in the same manner as for oak. Insects and fungi do but little damage.

Sycamore or Great Maple (Acer pseudo-platanus).

A native of Central Europe and Western Asia, it was introduced into Great Britain during the fifteenth century. It is a tree of the hills and withstands strong winds well. It is rather tender to late frosts. It stands half-way between lightdemanders and shade-bearers, and to do well as high forest requires a full amount of light. As coppice it will stand a fair amount of shade, and it can be used for underplanting the more open spaces in oak, ash, and larch woods. It requires a deep, fertile, fresh soil to do well, but it will grow on most kinds of soil provided there is a good depth. Some lime in the soil is advantageous. It grows well from seed, and its natural regeneration is easy. It coppices well when cut for the first time, but the stools do not last long. It can be grown as high forest, standards-over-coppice, or as coppice, and is best grown in high forest in groups mixed with other species, especially beech. It should be given plenty of space when its height growth begins to fall off. It is a rapid grower, and produces a tall clean stem if grown in crowded woods. It reaches maturity at from eighty to one hundred years. Large timber usually sells well, but small trees are of small value. Insects and fungi do but little damage. The fungus Rhytisma acerina causes the black spots found on the leaves.

The Norway Maple (Acer platanoides).

Has much the same sylvicultural characteristics as the sycamore, but thrives further north. It is more a tree of the plains than of the hills, and is specially suitable for planting near the sea. It suffers less from late frosts, and is not so 
exacting as to soil. Its timber is not quite so valuable as that of the sycamore.

\section{Tulip tree (Liriodendron tulipifera).}

A native of Canada and the United States, it was introduced into Europe in 1663 . It is an ornamental tree for park planting, and has not been planted in woods. It suffers from late frosts and should therefore be grown in sheltered situations; it does best in the south of England, and thrives in London parks. It is a light-demander. It does best on a deep loamy soil. It is a difficult tree to transplant, and therefore is not likely to be grown on a large scale as a forest tree in England, though its timber is used for furniture and other purposes under the names of 'White Wood', 'Canary Wood', and 'Yellow Poplar'.

\section{Walnut (Fuglans regia).}

A native of Greece, but has been cultivated in Great Britain for many centuries. Although here grown chiefly as a fruit tree, its timber is of considerable value for gun-stocks and for furniture, and it would pay well if grown as a timber tree. It could be introduced in groups here and there in woods of other species on deep, dry, rather light loamy soils. It is a light-demander, and requires plenty of space. It should be grown in sheltered positions as it suffers from late frosts. It is grown from nuts which should be sown in rows two inches deep, and the seedlings should be transplanted at one year old.

The Black walnut (Fuglans nigra) and the Grey walnut (Fuglans cinerea) would also perhaps prove to be good forest trees in the warmer parts of England. Walnuts should be grown on a rotation of over a Ico years, as the valuable heartwood is not produced till the tree is fifty to sixty years old. 


\section{WILLOWS}

The Sallowe, Saugh, or Goat Willow (Salix caprea).

A native of Great Britain and Europe. It is found up to an elevation of 2,000 feet in Scotland. It will succeed on any aspect and on almost any soil, and is very hardy. It is lightdemanding and a rapid grower. It is not of much value and is usually considered as a weed, and is cut out in the cleanings and thinnings. It seeds well, but is ordinarily propagated from cuttings. It could be used to provide temporary shelter to more valuable trees in unfavourable situations.

\section{The White Willow (Salix alba).}

A native of Europe and Asia, and probably of Great Britain. It is very accommodating as to soil and situation so long as there is plenty of moisture, and is very useful along the banks of rivers and streams. It is light-demanding and hardy. It coppices and pollards well, and is the best willow for providing small material for cask hoops and basket-work. It is propagated from cuttings about 5 feet long. If grown closely it will produce a good length of clean timber.

A variety of this willow (Salix alba caerulea) is the best for cricket-bats, and Salix alba is the next best willow for this purpose. The female trees are said to be better than the male, and therefore cuttings of female trees should be obtained from Essex, Suffolk, and Herts., where the best willow for cricketbats is now obtained. Well-grown timber fit for bats fetches a very good price. Trees are usually ready for cutting at about thirty-five years of age. Timber with large rings and no heartwood is the most valuable.

\section{Crack Willow (Salix fragilis).}

This willow will grow in most soils and situations provided there is sufficient moisture. It is a very hardy and quickgrowing tree. It is treated and propagated like the white 


\section{THE BROAD-LEAVED TREES}

willow. It is not so good for basket-making, and only makes inferior cricket-bats.

The Osier (Salix viminalis).

The osier is not a tree-willow, and is solely planted for coppicing in osier beds to provide material for basketmaking. It requires a fertile soil, and succeeds best along river beds in low-lying land which is occasionally flooded. It is light-demanding and a rapid grower. It is fairly hardy, but sometimes suffers from frost. The coppice is usually cut annually, and the stools last for twelve or fifteen years.

Willows, generally, are attacked by a large number of insects, but the damage done is not usually serious, nor do fungi do much harm. 


\section{CHAPTER XII}

\section{SYLVICULTURAL NOTES ON THE CONIFERS}

\section{THe CyPRESSES}

\section{The large-coned Cypress (Cupressus macrocarpa).}

A NATIVE of California, it was introduced into Great Britain in 1838 as an ornamental tree, but it will probably prove of use to foresters for planting as a windbreak, and also for underplanting as it is a good shade-bearer. It is fairly hardy and does well in open situations, but is apt to be injured by frost in low-lying damp places. It is storm-firm and withstands sea breezes and gales. It does best on deep, fresh, sandy loams. It is a quick grower. When grown in an open manner it branches down to the ground, and a belt of this species, planted on exposed sides of woods, would form an excellent shelter belt for young plantations against cold winds. The timber is of the same quality as that of the spruce, but as it has not yet been proved to be of use to timber-merchants it should only be grown on an experimental scale.

Lawson's Cypress (Cupressus Lawsoniana).

A native of California, it was introduced into Great Britain in 1854. It is an ornamental tree, and as its timber is of good quality, it may prove valuable for planting in woods, as it is a quick grower and hardy. It is a moderate shade-bearer, and does well on most soils provided they are not too wet, and on most situations except exposed places. It may be treated sylviculturally like spruce. It is good for underplanting.

The Red Cedar (Thuya gigantea).

A native of California, it was introduced into Great Britain in 1854 . It is very hardy against frost and will succeed on 


\section{SYLVICULTURAL NOTES ON CONIFERS ${ }_{1} 6_{5}$}

exposed situations, being storm-firm, though it does best in sheltered places, especially on northern aspects. It will stand a good deal of shade. It is accommodating as to soil, but prefers a deep fresh one, and likes some lime. It is a rapid grower, but not so fast as Douglas fir or larch. This tree may prove useful for underplanting on moist soils in the place of spruce as it bears more shade than the latter. It could also be grown in pure woods or as a mixture in groups with larch, but as its timber has not yet been proved to be valuable when grown in Great Britain, it should only be planted on an experimental scale at present. Its timber will probably prove to be excellent for gate-posts and for fencing purposes.

It suffers but little from insects and fungi.

\section{THe FIRS}

Douglas fir (Pseudotsuga Donglasii).

There are two distinct varieties of this important species: the Pacific or Green Douglas fir and the Colorado or Blue Douglas fir.

The Colorado variety has shorter and bluer needles, which are stiffer than those of the Pacific Douglas fir. If the needles of the two species are rubbed they have a distinctive scent, and it will be found that the Colorado has a much coarser smell than the Pacific. It is of the greatest importance in sylviculture to distinguish between these two varieties, as the Colorado is not nearly so useful a tree as the Pacific.

The Pacific Douglas fir is a native of the Rocky Mountains and Vancouver Island; it was introduced into Great Britain in I 828. It is a fairly hardy tree, but requires sheltered situations as its long leading shoot gets easily broken off, or bent, by wind. It also requires a damp atmosphere. It suffers from autumn frost in low-lying situations, but does not get much injured by spring frosts. Northern aspects are best. It bears a fair amount of shade. It is a very rapid grower, and in favourable situations will outgrow larch. It is fairly 
accommodating as to soil, but does best on a deep, fresh, sandy loam; it also does fairly well on stiff soils on the slopes of hills where there is a good natural drainage. It does not thrive on chalks or limy soils, or on dry soils. It can be grown in high forest as a pure wood, as it is soil improving; or it can be mixed with larch, preferably in groups; when mixed with other species it will probably outgrow and suppress them. It may be used for underplanting larch or other light-foliaged trees. When grown pure it should be planted at not more than 4 feet apart as, unless grown closely, the branches will not fall off early. At present, Douglas fir plants bought from nurserymen are very expensive, and it is far better to grow them from seed in the home nursery where they can be raised quite cheaply, with no difficulty.

The timber is of much the same character as that of larch, but ranks between it and Scotch pine in value. It is largely imported under the name of 'Oregon pine'. Although of less value than larch per cubic foot, it will possibly pay better, as a very much larger quantity can be grown on an acre.

It has not suffered in Britain to any great extent from insects and fungi, but a fungus, Botrytis cinerea, attacks the foliage of young plants in the nursery, while Phoma pithya causes cankerous disease on the twigs and branches. These fungi may increase and do serious damage. The pine weevil (Hylobius abietis) and the cockchafer seriously injure young Douglas fir, and other insects attacking conifers may spread to this species.

The Colorado variety is a much slower growing tree and is not worth planting on a large scale, at any rate in the south of England. It suffers considerably from spring frosts, and appears to grow best when under an existing crop of larch, oak, or other lightly foliaged tree. It may therefore prove of use for underplanting. Care should be taken when purchasing Douglas fir to see that this variety is not supplied in place of the green one. 


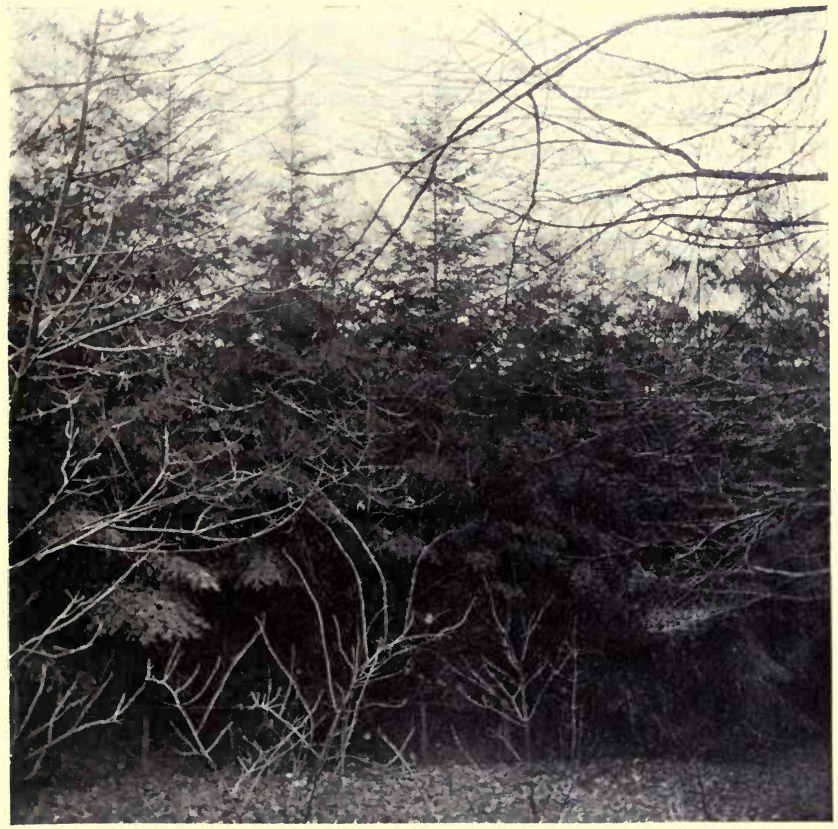

Douglas fir planted 1893 at 4 feet by 4 feet. Height 35 feet, girth up to 77 inches. Coopers Hill. January, I9IO. 


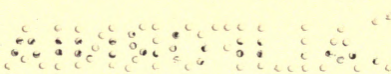


The Silver fir (Abies pectinata).

A native of Central Europe, it was introduced into Great Britain in 1603 . It requires warmth and is more suitable for the south of England than for Scotland. It does best on northern and eastern aspects in situations sheltered from wind, but does not thrive in low-lying frosty valleys. It is extremely sensitive to late spring frosts, and this is the chief danger to be guarded against. It is a great shade-bearer. It does best on a deep, fresh, stiffish loam, and prefers soils inclined to be stiff rather than sandy ones. The roots are deep going, and shallow soils are unsuitable. It can be grown in pure woods, but is better mixed with spruce. In England its chief use would be for underplanting larch or pine woods, which are to be grown to long rotations, as when growing under shelter it escapes damage by frost and greatly improves the fertility of the soil. If grown on blank areas it must be protected by larch or birch nurses planted beforehand. It grows extremely slowly for the first ten or fifteen years, but it then pushes ahead rapidly, and finally reaches a greater height than any other British tree with the exception of spruce and Douglas fir. To get clean timber it must be kept very dense, as the branches bear much shade and do not easily get killed off. It reaches maturity in Great Britain at about seventy years, its timber being used for the same purposes as that of spruce. On the whole it is not a profitable tree to plant, as it requires a good soil where more valuable species could be grown. Insects do not injure it much, but the fungus, Melampsorella Caryophyllacearum, causes witches'-broom and canker, doing serious harm.

Silver fir is a difficult tree to transplant and succeeds best where five-year-old plants are used, the planting being done in the late spring.

\section{Nordmann's Silver fir (Abies Nordmanniana).}

This tree is a native of the Crimea, and was introduced into 
Great Britain in 1845 . It is a far hardier tree than the common Silver fir, and it does not get injured by frost. It will therefore probably prove useful as a substitute for the common species. When once established it grows rapidly. It is accommodating as to soil, and resembles the spruce in this respect, doing fairly well on all soils which are neither very wet nor very dry. In other respects it resembles the Silver fir. It may be used for underplanting larch or pines.

\section{THE LARCHES.}

Common larch (Larix europaea).

A native of the hilly parts of Central Europe, especially of the Alps, it was introduced into England in 1629 and into the Lowlands of Scotland in 1725 . It does best in a situation resembling as far; as possible that of its natural home; that is, on high elevations and on cool north and east aspects. It is found in the Highlands up to an elevation of 2,000 feet, though it hardly pays to plant it at this height. Larch suffers from drought, but is fairly hardy against frost, though its foliage gets cut back by late frosts in low-lying damp situations, as it sprouts early in spring. It is storm-firm and a quick grower. It is a great light-demander and must not be grown where it gets in the least shaded by other trees.

A deep, porous, and fresh soil suits the larch best, and it does well on stony, well-drained soils along ravines. It will not thrive to a large size on land which is not well drained, but it will produce small timber on clayey soils. It does well on limy soils, but on gravels it is very liable to red-rot. Dry sands are also unsuitable.

Larch should not be grown in large pure woods as it gets much diseased, and after the thicket stage is passed the soil deteriorates under it. It should be grown as standards-overcoppice, or in small groups here and there in woods of other species, especially where there is plenty of beech or chestnut. It is essential to give it plenty of space, and thinnings in pure 


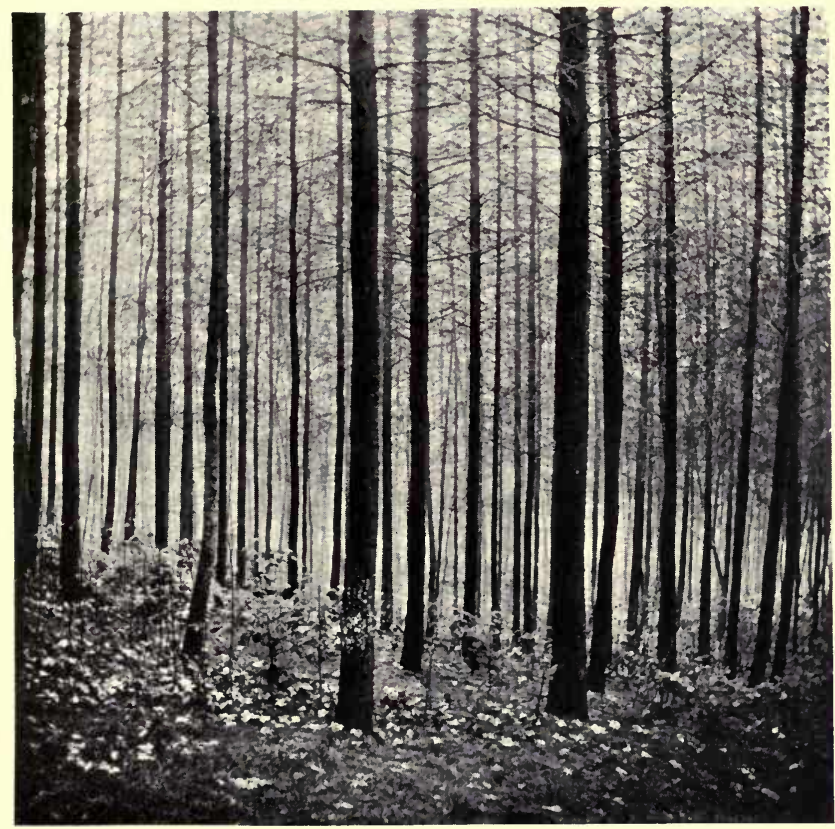

Larch planted I89I at 4 feet by 4 feet. Thinned in 1903 and underplanted with silver fir. Height 45 feet, girth up to 26 inches. Coopers Hill. January, 1910. 

woods should be fairly heavy throughout, underplanting being resorted to, to keep up the fertility of the soil. The timber is usually ripe for the axe at from sixty to eighty years of age, though in favourable situations it can be grown on to much larger size. It is, perhaps, the most valuable timber grown in Great Britain, being used for a great variety of purposes. It suffers considerably from insects and fungi. ${ }^{-}$Of the insects, the worst are the larch aphis (Chermes laricis), the larch miner moth (Coleophora laricella), and the larch shoot moth (Argyresthia laevigatella), while the sawfly (Nematus Erichsoni) has recently done very serious clamage. Of fungi, the worst is the well-known larch canker, Dasyscypha calycina; this is now found in almost every larch wood in England and may make the cultivation of larch impossible except in the most favourable situations.

The Fapanese larch (Larix leptolepis).

A native of Japan, this tree was introduced into Great Britain in $186 \mathrm{I}$. It is of more rapid growth during youth, but when about twenty years old it is overtaken by the common larch. It is a more hardy tree and suffers less from insects and fungi, and it has been said that it is not attacked by the larch canker: this is, however, not the case. It may be treated sylviculturally like the larch. Where larch is grown extensively this species may be substituted for the common larch here and there, but it is doubtful whether it will prove such a valuable tree.

Of other larches, the Western larch (Larix occidentalis) may prove to be a useful tree, but neither the Kurile larch (Larix curilensis) nor the Siberian larch (Larix siberica) are likely to be of much value for forest growth.

\section{THE Pines}

The Scotch pine (Pinus sylvestris).

A native of Scotland and of the countries round the Baltic. It is found up to an elevation of 2,200 feet in Scotland, but 
does best on low lands. At high elevations southern aspects are best for it, as it succeeds best in a warm climate, but at low elevations it will do well on all aspects. It is hardy against frost and drought. It is very light-demanding and should not be grown in the shade of other trees. It is stormfirm, being deep rooted, but heavy snow breaks off many branches. It is a rapid grower. It is very accommodating as to soil, and can be grown on almost any class of land except very shallow soils. It succeeds best, however, on gravelly loams and sandy soils, and it is a useful tree for peats. Depth and plenty of moisture are necessary for its finest development, but useful timber can also be obtained on dry and moderately shallow soils. It is one of the best trees for a first crop on land not previously wooded.

Scotch pine may be grown in pure woods up to an age of forty or fifty years as it preserves the fertility of the soil till then. After this age the woods open out, and if they are to be grown on to a long rotation they should be underplanted. It is, however, better to mix Scotch pine in fair-sized groups with beech, spruce, or Douglas fir, while groups of larch may be planted here and there in pine woods to improve the revenue. High forest with clear cutting is the most suitable sylvicultural system with a rotation of about sixty to eighty years. On sandy lands covered with a short growth of heather natural regeneration will usually be successful. The timber of Scotch pine is largely imported under the names of 'Red deal', 'Red fir', 'Red pine', and 'Yellow pine'. British-grown timber only fetches a small price as it is almost invariably knotty and soft, having been grown in too open a manner, but if grown properly in crowded woods there is no reason why home-grown timber should not be quite as good as the foreign. Insects do serious damage, the chief pests being the pine weevil (Hylobius abietis), the pine beetle (Myelophilus piniperda), the cockchafer (Melolontha vulgaris), and the pineshoot moth (Retinia buoliana). Fungi, especially the Honey 
fungus (Armillarea mellea), the red-rot root fungus (Fomes annosus), and the pine blister (Peridermium pini), do much harm. With so many insects and fungi attacking Scotch (and other) pines, it is especially necessary to keep the woods clean by having light thinnings made every five years to remove dead wood and unhealthy trees. In pure woods the thinnings should be light in character throughout the rotation so as to keep a complete cover over the ground, but if the woods are to be underplanted, with the intention of growing them to a long rotation, they should be made heavier about the forticth year so as to admit sufficient light for the undercrop, and to encourage the pines to increase rapidly in girth.

The Austrian pine (Pinus austriaca).

A native of Austria, it was introduced into Great Britain in 1835. It is a very hardy tree and can be grown at high elevations, and also near the sea, as it withstands wind. It will do well on any aspect. It is a light-demander, but will stand side-shade rather better than the Scotch pine. It is very accommodating as to soil, but does not do well on stiff wet ground; it thrives on limy soil. It is not as valuable as the Scotch or Corsican pines and should not be grown on a large scale. Its chief use will be as a shelter belt; for this purpose it is excellent, as it forms a thick hedge when allowed to branch low down, and grows rapidly when young. It is also useful for planting on poor limy soil and on dry chalks which have deteriorated; it would soon improve such a soil and could be cut at an early age, when a more valuable species could be substituted for it. The timber is coarser than that of Scotch pine. Austrian pine is attacked by the same insects and fungi which damage the Scotch pine.

The Corsican pine (Pinus Laricio).

This tree is a very close relative of the Austrian pine, but it is a native of Corsica and southern Europe. It was introduced into Great Britain in I759. It is a hardy tree, but does 
not do so well as the Austrian pine on high elevations or in windy places. It does well near the sea. It is a light-demander. It is of much more rapid growth than the Austrian pine and is a more valuable tree altogether, as it grows with a taller, cleaner, and straighter stem. It is deep rooted and does best on deep, light, dry, sandy loams, and thrives on limy soils. It does not grow well on wet clays. It can be treated sylviculturally like the Scotch pine, with the exception that greater care must be taken in transplanting it, as it forms very weak roots in the nursery and is therefore a bad transplanter. It succeeds best when planted as two-year-old seedlings, and these should be planted into the woods in the last half of October or in late April. Where larger plants are used, often fifty per cent. die if there happens to be a warm, dry summer after planting. It is attacked by the same insects and fungi as the Scotch pine, but is said to be less eaten by rabbits.

The timber is of about the same value as that of the Scotch pine.

\section{The Cluster or Maritime pine (Pinus Pinaster).}

A native of the south of Europe, it was introduced into Great Britain in I596. It is a fairly hardy tree when grown on the sea coast, but is not suitable for high inland exposed places. It is one of the best trees to grow along the coast as it withstands the salt winds excellently, and is of great use in forming shelter belts behind which other species may be grown. It is a light-demander and must be given plenty of space. It does best on a deep dry sand or a light loam. It does not succeed on limy soils. The timber is used in France for boards, packing-cases, \&c., and large quantities of pitwood are exported to England, but home-grown timber is inferior and of much less value than that of Scotch pine.

The Weymouth pine (Pimus Strobus).

A native of Canada and the United States, it was introduced 
into Great Britain in 1705 . It is very hardy, but to do well it requires a sheltered situation. It stands about half-way between light-demanders and shade-bearers. It has a deep growing root system and is storm-firm. It will produce good timber on any aspect. It prefers a deep, fresh, loamy sand, but is very accommodating and can be grown on almost any soil provided it is not very dry. It is a quick grower and will produce a much larger volume of timber per acre than the Scotch pine. It can be grown in pure woods, but does very well when mixed with other conifers or beech. It thrives best when fully exposed to light, but it can be used for underplanting larch or Scotch pine, as it improves the soil ; it is useful for filling in blanks in existing woods. It can be cut on a rotation of sixty to eighty years. The timber is largely imported under the name of 'Yellow pine', though it is called 'White pine' in America, and is used for house-building. Home-grown timber is, however, not very durable and is more suitable for paper manufacture and for packing-cases and other purposes where a light soft wood is wanted. It is a very ornamental tree, but it is not valuable enough to plant as a forest tree except on a small scale.

Weymouth pine suffers from much the same kinds of insects and fungi as the Scotch pine, but to a less extent. Periderminm strobi, the Weymouth pine bark blister, causes much damage to young trees, and Chermes corticalis, an insect forming a woolly covering on the stem, does serious harm in many localities.

Many other pines are grown as ornamental trees, but none of them are of much sylvicultural interest. Possibly Banks' Pine (Pinus Banksiana) and the Remarkable pine (Pinus insignis) may be of use in certain localities to fix shifting sands on the sea coast, while the dwarf Mountain pine (Pinus montana) is useful for providing cover for game at high elevations above the limit of ordinary forest tree growth and for the outer rows of a shelter belt. The Cembran pine (Pinus 
Cembra) is very hardy in exposed situations and may be used as a shelter belt, but it is of slow growth.

None of these species will produce paying timber, except possibly Pinus insignis.

\section{The SPRUCES}

The Common or Norway spruce (Picea excelsa).

A native of Europe, it was introduced into Great Britain about ${ }_{1548}$. In Europe it is a tree of the mountains requiring but little warmth, but in England it seems to succeed best in low-lying sheltered places; north and east aspects being the best. It grows far better in Scotland than in England. It is fairly frost-hardy, but is very sensitive to drought, and does best where both the air and soil are moist. It is easily blown over by gales, and is the least storm-firm of all British forest trees when grown in woods, but trees grown in the open have roots which spread to a great distance and are fairly stormfirm. It bears a light shade, but to do well it must be grown fully exposed to light; it does not appear to bear as much shade in Great Britain as it does on the Continent. It is fairly accommodating as to soil provided that there is sufficient moisture, and it will succeed on shallow soils as it has not got deep-going roots. It does best on fresh or moist loams, and on such a soil produces the best class of timber, but it will succeed fairly well on moist sands and on clayey soils.

It is a slow grower for the first few years, but when once it starts growing, at about the tenth year, it continues to grow at a very rapid rate.

It is suitable for pure woods as it is a soil-improving species, but it is better to grow it in mixture as a subordinate species with more valuable trees such as larch or Scotch pine in groups. It is not very suitable for underplanting, though it can be used in the more open spaces for this purpose. It should be planted closely, at a not greater distance than 


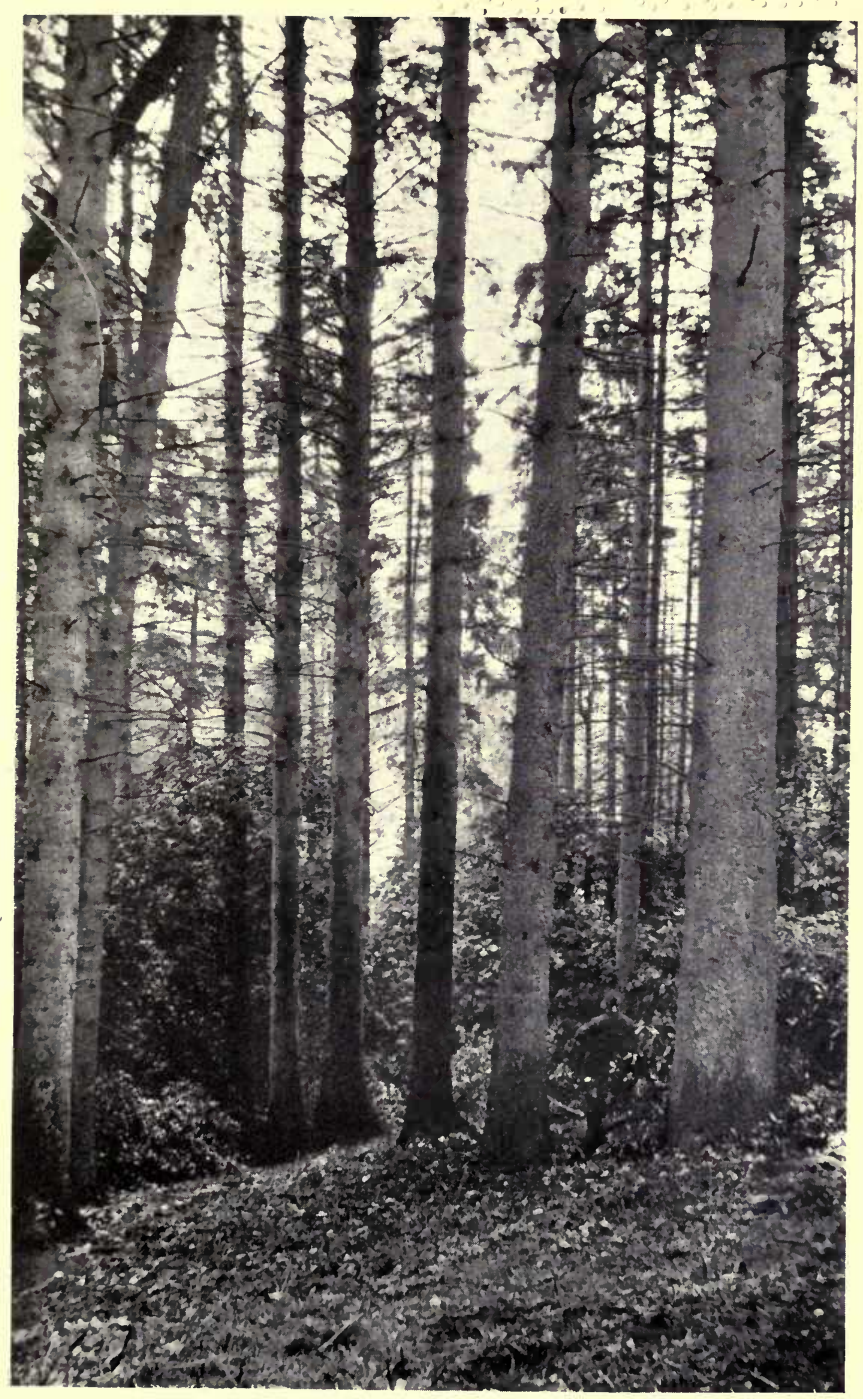

Mature spruce at Walcot. Photograph by M. C. Duchesne. From the Quarterly Journal of Forestry. 


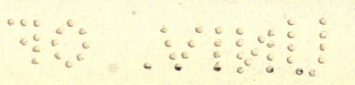


4 feet by 4 feet, and thinnings should be very lightly conducted, because clean timber will never be obtained if the trees are grown in anything approaching an open state. It is mature at from sixty to eighty years of age. The timber is largely imported from the Baltic under the names of 'White deal' or 'White fir'. Home-grown timber is usually very full of knots, but this is due to the fact that it has mostly been grown in woods of too open a character.

Spruce does not usually pay well in Britain when grown on small areas, but large woods of this tree would probably be very profitable for the manufacture of pulp for paper.

Spruce suffers greatly from insect attack and from fungi. The pine weevil and several bark beetles do much damage, and the Spruce gall aphis (Chermes abietis) injures young plants. Of fungi, the Honey fungus (Armillarea mellea) and Fomes annosus do much harm, while Pestalozzia Hartigii causes young plants to turn yellow and die.

\section{The Sitka spruce (Picea sitchensis).}

A native of America, it was introduced into Great Britain in $183 \mathrm{I}$. It is a very ornamental tree, of rapid growth and is hardy. It is a moderate shade-bearer and can be used for underplanting. The timber is of a better class than that of the Common spruce, and the tree will probably prove to be worth planting on a large scale in place of the latter. It will succeed on all fairly deep soils except dry sandy ones, and it is a useful tree for stiff clays. It can be treated sylviculturally like the Common spruce. The needles being very prickly it escapes damage from animals to a great extent.

Unfortunately, the Honey fungus attacks it very badly and may prevent large-scale planting.

\section{The Yere (Taxus baccata).}

A native of Great Britain. This is a common tree in our woods and is widely distributed, but it is in no sense a tree 


\section{I76 SYLVICULTURAL NOTES ON CONIFERS}

which is grown for profit. It usually only attains a height of 30 to 40 feet, and is a very slow grower, but lives to a great age. It is ornamental, and a few specimens in the woods are not out of place. It is hardy and will grow on most situations, and is a great shade-bearer. It will grow on all soils except dry sandy ones, but it does best where there is plenty of lime. The timber is hard and very durable, takes a fine polish, and makes excellent furniture. Any yew that may happen to be cut can be used for fencing-posts, as it is extremely durable and will outlast iron. In olden days it was used for making bows. 


\section{CHAPTER XIII}

\section{FENCING AND DRAINING}

IT is usually necessary to enclose all woods and plantations with an efficient fence of some kind to keep out cattle. For this purpose a hedge, wire fence, or stone wall is required.

\section{HEDGES.}

A hedge forms a very effective fence so long as it is kept in good condition, and in addition to keeping out cattle, it also gives some shelter to young plantations. It has the disadvantage of not forming a fence for some years after it has been planted, and during these years it has to be itself protected by a temporary fence of some kind. Hedges are therefore expensive to form, but once made they will, if well cared for, last a century and more. In the great majority of cases the best plant to use is whitethorn, or quick, as it flourishes in a great variety of soils and situations. It is, however, an unsatisfactory hedge at very high elevations, and the young plants in such places are difficult to establish. Whitethorn lives for a long period, and if kept well trimmed, animals will seldom be able to force their way through it. It is a light-demanding species, and therefore plantations should be formed at such a distance away from the hedge that it is not likely to be overshadowed when the woods grow up. This is a disadvantage, as it necessitates the loss of a good deal of area. The branches of trees which overhang a hedge should be pruned off, and around woods no trees should be grown in the hedge.

Formation of a new hedge. Hedges may be formed on 
a flat surface or on a bank. The advantage of using a bank is that an effective fence is obtained within a few years, but for all other reasons planting on the flat is best, as a hedge thus formed lasts longer. The bed should be prepared with care; it should be dug to a width of $4 \frac{1}{2}$ feet, of which the middle $\mathbf{I} \frac{1}{2}$ feet should be 2 feet deep, and the rest $\mathbf{I}$ foot. This work should be finished at least a month before planting begins, at any time in open weather, from November to March. Three-year-old plants may be used, and these can be placed in single or double rows. The Midland Railway Company plant two rows of quick, 4 inches apart, with the plants 8 inches apart in the rows, the plants in one row being opposite the spaces in the other row. There are thus about I 90 plants to the chain. On the Thorney estates, recently owned by the Duke of Bedford, the plants are placed in single rows with the quicks 4 inches apart, the number of plants to the chain being the same as above. Others prefer to place the plants 8 inches apart in two rows with 8 inches between the rows, as it is easier to weed the bed with a hoe. As all the above systems give excellent hedges, if afterwards managed properly, it is a matter of small importance which method is used. When planted, the quicks are cut off to a uniform height, about 2 or 3 inches above the ground, and this may be done at once or in the first April after planting. They are then left to grow on.

When a new hedge is to be formed on the site of an old one it is essential to renew the soil. This may be done by making a wide deep trench which is then filled up with soil from the adjoining field or wood. The soil may be obtained by digging another trench within the wood at a spade's throw away from the hedge, the soil from the first trench being thrown back into the second one to fill it up.

As soon as the hedge is planted it must be protected from cattle by a temporary post-and-rail fence.

After management. The bed must be kept clean of weeds, 
and during the first few years a hoe or Dutch hoe may be used between the plants. Later on the weeds must be persistently cut back with a hook.

There are two ways of obtaining a good hedge, and either may be adopted. The first method is to trim the hedge into the shape desired by annual trimmings, the first of which is made in the third year after planting. In the course of a few years a good dense hedge is thus obtained. This annual trimming may be done at any time in autumn or winter, while a second trimming in summer between hay time and harvest is of great advantage. Another system, carried out by the Midland Railway Company, is to allow the young quicks to grow up to a height of 6 or 8 feet without any trimmings; they are then layered or laid, an efficient fence being obtained as soon as this is done. Live stakes are left 2 feet apart; the rest of the rods are partially cut through at the base and are bent down and wattled between the stakes at an angle of about forty degrees with the ground. Young shoots arise from the cut surface and fill up the bottom of the hedge. In future years the hedge is trimmed annually to the desired shape.

Ditch and Bank. Where it is desirable to have a ditch along the fence to prevent cattle breasting the hedge the bank may be formed as is done in Leicestershire.

A ditch is cut 3 feet wide and 2 feet deep, the soil taken out being formed into a bank about I foot high with a flat surface. The quicks are planted in the centre of the bank, the future management being the same as on flat ground. The ditch should be sufficiently near the bank to prevent cattle from placing their feet on it, as they are then unable to apply their weight to the temporary post-and-rail fence which is made on the top edge of the bank. The quicks should be placed well away from the ditch, as otherwise soil falling off the bank may expose the roots.

Preservation and restoration of old hedges. A hedge once 
formed should be trimmed annually, and if this is done it can be kept in good condition for thirty or forty years and more. When this has not been done it will usually become gappy and useless, and must be restored. Often such a hedge is cut down to the ground to coppice, but this is a bad method as there is then no effective fence for some years. When it is short and gappy it must be allowed to grow for some years till it is tall enough to be laid; this can be done immediately with high rough hedges. First, all decaying stumps should be cut off level with the ground, and rods for wattling should be chosen from the most vigorous stools, the straightest being preserved and all others not wanted being cut out. Honeysuckle, clematis, brambles, rose, and elder should be got rid of as they do great harm. The bank, if there is one, should be repaired. Stakes, cut if possible from material in the hedge, are placed at 2 feet apart, and the rods are then half cut through a few inches from the ground with, whenever possible, an upward cut; these are bent downwards and are wattled between the stakes. The brush should be trimmed off nearest the hedger, so as to leave a straight side, as this facilitates his work. Care must be taken not to put in too much material as otherwise there is insufficient room for young growth. The hedge may be laid, where there is no bank, to a height of 4 feet, but on a bank it may be less than this. After the rods are laid the brush is trimmed and a header or binder, which consists of a number of thin hazel rods, is interwoven about the tops of the stakes. This keeps the brush down and increases the strength of the hedge. In future years the hedges should be kept in good condition by annual trimmings.

Cost of hedging operations. The cost of the various operations described is approximately as follows :-

Preparation of flat bed, about $2 s$. per chain.

Cost of three-year-old plants, about I 5 s. per I,000.

Cost of planting ditto, about is. per chain. 
Cleaning during first few years, about Is. per chain. Laying young hedges, about $3 s .4 d$. per chain.

Laying old hedges, about $4 s$. per chain.

Annual trimming, $6 d$. per chain.

Post-and-rail protective fences, about $25 \mathrm{~s}$. per chain.

Post-and-wire, with top rail, about 20 s. per chain.

Post-and-wire, about $\mathrm{I}_{5}$ s. per chain.

Other plants used for hedges.

Blackthorn. A good hedge plant on strong loams, but it often spreads into the neighbouring fields by suckers. It should only be substituted for whitethorn on strong wet soils.

Myrobella or Cherry Plum. A good plant on soils suitable for pluns. It produces stout thorns and forms an efficient fence very rapidly. It will stand sea breezes.

Beech makes a good hedge in exposed situations, and is useful when shelter is wanted. It does not, however, make a strong fence against cattle. The plants should not be closer than 18 inches and should not be cut back when planting. It may be trimmed after the second year.

Hornbeam is a shade-bearer, and makes a good hedge under the shade of other trees. Its dead leaves remain on in winter and it therefore gives good shelter.

Holly makes a strong fence and gives good shelter. It grows slowly, but lasts a long time. It does well in thin sandy soils, and will grow under hedgerow trees, as it is a shade-bearer.

Gorse makes a gond fence if grown on a bank, and can be used on barren sand and in exposed places where other plants will not grow. Yere, Box, and Privet do not make strong enough fences for forest purposes.

\section{Wire Fences.}

A wire fence has the advantage over a hedge in that it keeps out cattle immediately it is made, and is usually cheaper 
to erect; on the other hand it will only last some twenty years, and it gives no shelter. Nevertheless, wherever hedges do not exist already it will usually be best for the present owner to put up a wire fence round his plantations in order to obtain immediate effect, and because a wire fence requires very little repairs in future years.

There is a great variety of fences which can be erected, but it is not necessary to enumerate or describe them in this book. For the purpose of forestry it is usually best to form a fence with wooden posts, if possible of oak or larch cut from the woods on the estate. Their durability may be increased by charring and tarring the parts which go below ground, and for a few inches above the ground level. To protect plantations against cattle and sheep an efficient fence is as follows :Strong posts of oak or larch, roughly squared with the axe to 7 inches square on the part above the ground, and left rough on the part to go below ground, are cut 7 or $7 \frac{1}{2}$ feet in length. These are used as straining posts, and are placed at all corners of the fence and at intervals of about 200 yards in all straight parts. They are let into the ground to a depth of 3 feet, leaving 4 or $4 \frac{1}{2}$ feet above ground. They are supported with stays about $7 \frac{1}{2}$ feet long placed in the line of the fence to prevent the straining posts being pulled out of position. At intervals of 50 or 60 yards intermediate posts about 5 inches square may be placed.

At every 6 feet piles or standards are driven into the ground. These may be made of split oak or of sawn larch, and are 6 feet long, and about $3 \frac{1}{2}$ inches by 3 inches, and are pointed. If round stakes are used they should be $3 \frac{1}{2}$ inches diameter at the small end. These are driven in after the lowest wire has been stretched to give the line, and are best erected with a slight lean outwards.

To make a good fence on the flat it is usually necessary to use 8 wires, the lowest being .5 inches from the ground and the others $5,5 \frac{1}{2}, 5 \frac{1}{2}, 6,7,8$, and 9 inches from the one below ; 
the top wire being 3 inches below the top of the posts. This gives a fence 4 feet 3 inches high. On banks 5 wires will be usually sufficient to form a fence 2 feet 6 inches high. Wires should be of the best galvanized drawn wire, and the two top ones should be No. 6 gauge, of which about 390 yards go to the cwt. ; while the others can be No. 8, giving about 570 yards to a cwt. They should be fixed to the posts with $I \frac{1}{2}$ inch galvanized staples, which should not be driven tightly on to the wire except at the straining posts. Any form of straining machine can be used to tighten the wires; screwed eye bolts are good, as when these are used the wires can be tightened or loosened when necessary without trouble. Winder brackets are also good. The top of the posts should be sawn off at an angle to prevent water lodging on them.

The cost of the 8-wire fence described above will be from $1 s$. $6 d$. to $2 s$. per yard; it varies according to the price of wire. The large straining posts can be made from homegrown material for about $2 s$. each, intermediate posts for about $5 d$., and the pointed piles for about $2 \frac{1}{4} d$. The cost of the fence should be kept as low as possible by putting in as few wires as will serve the purpose.

Where rabbits alone are to be kept out the following makes an efficient fence :-

Use posts cut from the woods, of larch, oak, ash, or chestnut, 4 feet 9 inches long, about as thick as a man's arm ; set these I 2 feet apart driving them I foot 6 inches into the ground, and have stronger posts at the corners. Put up one top wire, No. Io gauge, at 3 feet from the ground. To this tie galvanized wire netting 42 inches wide, $I \frac{1}{4}$ inch mesh, and No. 17 gauge. Turn 6 inches of this under the turf towards the outside of the plantation, or if the soil is very sandy, drop 6 inches vertically into the ground, to prevent rabbits burrowing under. The author erected a fence as above some five years ago at a cost of $4 \frac{1}{2} d$. per yard, excluding the cost of stakes, which were cut on the ground, and up to date no rabbits have got into the enclosure. 
Where a wire fence already exists it can be made rabbitproof by attaching wire netting to it, care being taken to take the above-mentioned measures to prevent the rabbits burrowing. Netting must also be put on all gates and across drains running under the fence.

In order to reduce the cost per acre it is important to enclose as large an area as possible at one time, as small enclosures cost more per acre than large ones. Thus, in square plantations, an area of one acre requires 280 yards of fence, and four acres requires 560 yards. If the fencing costs $I s$. per yard the one-acre plot costs 280 s., while the four-acre plot costs I4Os. per acre.

\section{WALLS.}

These give good shelter, but nowadays they are seldom made, as it is usually considerably cheaper to use wire fences. Even if wooden posts cannot be obtained in the neighbourhood iron ones can be erected, and the fence will not usually cost as much as a stone wall. Where stone is very plentiful a wall may possibly be desirable, and if so it should be built to a height of about 3 feet 9 inches without lime or mortar, except that the top stones should be bedded in lime to keep the wall from falling.

\section{Drainage.}

Swampy ground is unsuitable for the growth of trees because the roots cannot get a good hold of the soil, and the trees may afterwards be blown down by gales; moreover, as the soil contains no air, growth is stunted and the roots decay. Wherever possible, however, it is better to plant some species such as poplar, willow, alder, or spruce, which will grow to a certain size on swampy land, than to go to the expense of draining in order to grow a more valuable species. In many cases one or two shallow drains, dug to remove the surface water, will enable the area to be planted up with these species. 
Before draining a large area the consequences must be carefully considered, as otherwise unlooked-for results may be obtained. For instance, the drainage of an extensive swamp at a high elevation may reduce the water level of a large tract of lower lying country, and may thus do damage to agricultural land, and brooks and streams may dry up. For these reasons the woodman should only drain small local swamps unless expert advice is first obtained. Drainage should be done while land is bare of trees, as if it is carried out in existing woods, the water level being reduced, the standing trees may die. The best time to drain land used for forest purposes is about three years before planting, as the ground then settles, and the new water level finds its place, before the trees are planted.

In forestry, open ditches are used, because pipes would soon be choked up by the roots, and because ditches are cheaper. Where drainage has been decided on, ditches are dug at from 16 to 22 yards apart according to the soil; the stiffer this is the nearer must be the drains. The depth may vary from 4 feet on very stiff soil down to about 2 feet on lighter land. The width depends on depth, the general rule on the lighter soils being to make the width of the top of the drain one-third wider than the depth; thus a drain 3 feet deep should be 4 feet wide at the top, the sides being given a suitable slope to prevent the soil falling in. On stiff soil the width may be about equal to the depth, and the sides can be almost vertical. The bottom of the smallest drain made should be a little wider than a spade, so as to enable it to be easily cleaned out.

In laying out a drainage system a main drain should be made along the line of lowest level, and this should terminate in a stream or existing large ditch. From this, other large drains, called leaders, are made along the lowest depressions to all parts of the area, and from these the feeder drains are laid out. All ditches should fall into the larger drains in such a way that the water will not scour away the sides. The 
feeders need not be so large as the main drain or leaders, and are usually about 2 feet deep, and $2 \frac{1}{2}$ feet wide at the top; these run to all parts of the area. A fall of about I foot in every 100 feet should be given to all drains, with rather more on very stiff soils.

The ditches should be dug in the driest part of the year, and the earth taken out should be thrown over the surrounding land, as if left on the side of the drain it may fall in again. Wherever the drain has to pass under a ride or road a culvert must be made, or a pipe can be used.

Care must be taken to periodically clean out all ditches or they will get filled up with dead leaves, \&c., and will be useless.

Webster in Practical Forestry gives the following as being approximately the average cost of draining:-

Ditches $3^{\prime}$ wide at top, $2^{\prime} 6^{\prime \prime}$ deep, and $9^{\prime \prime}$ wide at $\begin{array}{rrrrrrr}\text { bottom... } & \ldots & \ldots & \ldots & \ldots & \ldots & 3 /- \text { to } 4 /- \text { per chain. } \\ \text { Scouring out ditto } & \ldots & \ldots & \ldots & \ldots & \ldots & 9\end{array}$ Small ditches $15^{\prime \prime}$ to ${ }^{\prime} 8^{\prime \prime}$ wide at top, $12^{\prime \prime}$ to $13^{\prime \prime} 9 d$. to $1 /-$ per chain. deep, and $9^{\prime \prime}$ wide at bottom $\quad \ldots \quad \ldots . \quad$ I/6 to $2 / 6$ per chain. $\begin{array}{lllllll}\text { Scouring out ditto } & \ldots & \ldots & \ldots & \ldots & \ldots & 6 d \text {. to } 9 d \text {. per chain. }\end{array}$ 


\section{CHAPTER XIV}

\section{FELLING AND MEASUREMENT OF TIMBER}

ON a large estate it is best to have a staff of woodcutters who are given permanent employment, as temporary men may not take the same interest in their work, and are then not likely to do it so well as the home staff. On small estates, where permanent work cannot be given, only experienced woodcutters should be employed. Whether the timber is sold standing or felled it should be cut by men employed by the owner, except perhaps where the area is to be clear cut, in which case the purchaser may be allowed to employ his own men, as they do not have much chance of doing harm.

Woodcutters should be paid by piecework for all ordinary work, but when they are cutting standards over natural regeneration or are thinning young woods, where special care is required, payment should be made by the day, as otherwise sufficient care will not be taken to prevent damage to standing trees.

Fellings in uncven aged woods, such as those managed under the selection method, where the trees are of different height, are always more difficult to carry out without damage than in woods of even age.

Fellings should take place in winter, as timber felled at this period is more durable than that felled in summer. The work is usually done with axe and saw combined, there being far less wastage than when the axe alone is used.

No amount of reading will enable the young woodman to cut a tree, and no description will therefore be attempted here as to the method of felling. Practical experience must be 
gained by working with an expert woodcutter, and it is satisfactory to know that a good British woodcutter is as good as any in the world. There are, however, a few general rules to which the woodcutter should pay attention. These are as follows :-

I. An endeavour should be made to throw every tree in such a way as to do the least amount of damage to surrounding standing trees, and young growth. If the tree to be felled has a large crown, and is surrounded by natural regeneration, it may be necessary to lop off all large branches before felling it, though if the young growth is close under the tree this is not necessary, as the crown would fall beyond it. Lopping is dangerous work, and should be avoided if possible.

2. Each tree should be thrown in the direction where the least damage will be done to itself. On steep slopes trees should be thrown along the contour line, as the crown has then only a small distance to fall, and the tree is less apt to be broken than when it is thrown downhill. A tree thrown directly uphill may shoot backwards, and is therefore dangerous to the woodcutters. Trees should not be thrown across rocks or felled logs, as they may break, and for the same reason they should not be felled across depressions in the ground. Trees felled in frosty weather are more likely to break than those cut on damp days, as they are less flexible.

3. In felling trees, attention should be paid to easy removal of the logs. They should not therefore be thrown into ravines or ditches. On slight slopes they should be felled uphill, as they are more easily dragged out when the butts lie downwards.

4. During heavy wind felling should be stopped. This is specially important when felling amongst young growth. It is dangerous to the woodcutter to fell in a strong wind if there are other gangs near him, as the noise of the wind prevents him hearing what is going on. The safest place, as the tree falls, is near the stump at right angles to the direction in 
which the tree is falling. When felling uphill the most dangerous place is behind the stump.

5. Trees must be felled in such a way as to reduce wastage to the minimum. They must therefore be cut as close to the ground as possible, and the saw should be used in preference to the axe, the latter only being used to trim the butt in readiness for the saw, and to cut a notch in the side on which the tree is to fall.

6. Where coppice is cut with the intention of obtaining a further crop of coppice shoots the surface of the cut should be left as smooth as possible. The value of coppice in most parts of England is now, however, so low, that too much time should not be spent on trimming the stools.

Each tree, when felled, must be converted into the most valuable material obtainable. Thus, if logs and pitwood are saleable no tree should be cut up into pitwood if it is possible to sell it as a log, as the price per cubic foot is much less when it is sold as pitwood. Logs of broad-leaved trees should ordinarily be cut off at the point where they are 6 inches in diameter, while conifers are usually run out to 3 inches, but the sizes vary in different localities. The woodcutter should be given instructions as to what are the proper sizes of the various classes of produce.

When the cutting is completed all produce should be ranked up according to its quality and size, and should be sold as early as possible, so as to get the ground clear for replanting without more delay than is necessary.

\section{Measurement of felled timber. ${ }^{1}$}

The true volume of a $\log$ is found by taking its girth, or diameter, in the middle; calculating the sectional area of this place; and then multiplying the sectional area by the length. The sectional area means the number of square feet or inches

${ }_{1}^{1}$ The calculations in this chapter are made as simple as possible, but it is assumed that the woodman has a knowledge of decimals. 
on a section cut in the middle of the log. This may be found from the girth by the formula :-

$$
\text { Sectional area }=(\text { girth })^{2} \times 0.0796
$$

the expression (girth) ${ }^{2}$ being read as 'girth squared', and meaning girth multiplied by girth.

The volume is therefore :-

$$
\text { (girth) }{ }^{2} \times 0.0796 \times \text { length. }
$$

Thus if a $\log$ has a girth in the middle of 6 feet, and is 20 feet long, the volume is

$$
6 \times 6 \times 0.0796 \times 20=57 \cdot 3^{1} \text { cubic feet. }
$$

To make the working-out of the sum shorter one can use the figure 0.08 instead of 0.0796 , in which case the cubic contents of the above log would come to

$$
6 \times 6 \times 0.08 \times 20=57.6 \text { cubic feet. }
$$

If the diameter in the middle of the $\log$ is measured with callipers, the sectional area is found by the formula :-

Sectional area $=(\text { diameter })^{2} \times 0.785$, and the volume is therefore :-(diameter $)^{2} \times 0.785 \times$ length.

Thus if a $\log$ has a diameter in the middle of 2 feet and length 20 feet, its volume will be:-

$$
2 \times 2 \times 0.785 \times 20=62.8 \text { cubic feet. }
$$

The above methods give the true cubic contents of the log, but the woodman will hardly ever be called upon to make these calculations in England, as timber is measured here by a system called the square-of-quarter-girth measurement, which makes an allowance of $21 \frac{1}{2}$ per cent. for wastage in conversion. By this system the volume is found by the formula :-

$$
\text { Volume }=\left(\frac{\text { girth }}{4}\right)^{2} \times \text { length }
$$

Thus if a $\log$ has a girth of 8 feet and length 20 feet, its volume is :-

$$
\frac{8}{4} \times \frac{8}{4} \times 20=2 \times 2 \times 20=80 \text { cubic feet, }
$$




\section{MEASUREMENT OF TIMBER}

whereas its true volume would be :-

$$
8 \times 8 \times 0.0796 \times 20=\mathrm{IOI} \cdot 8 \text { cubic feet. }
$$

If the quarter-girth is taken in inches and the length in feet, then the result must be divided by $\mathrm{I} 44$.

Thus if a $\log$ has a girth of 3 feet 4 inches and length 20 feet, its quarter-girth will be 10 inches and its volume:-

$$
\frac{10 \times 10 \times 20}{144}=\mathrm{J} 3 \text { feet } 10 \text { inches, }
$$

an inch being $\frac{1}{12}$ th part of a cubic foot, and not a cubic inch, which is $\frac{1}{172}$ th part of a cubic foot. An inch in timber measurement is therefore a block of timber equal to 144 cubic inches.

The true cubic contents can also be obtained approximately by this method, dividing by II 3 instead of by 144 , thus the true contents of this log will be :-

$$
\frac{10 \times 10 \times 20}{\text { II } 3}=17.7 \text { cubic feet. }
$$

A woodman who does not happen to be well acquainted with arithmetic will find this method to be the easiest one with which to work out the true volume of any log. It is sometimes used in England by railway companies to calculate the volume of logs upon which carriage charges are paid. True measure should be used in all measurements taken for scientific purposes.

It is sometimes useful to be able to turn true measure into quarter-girth measure rapidly. To do this deduct $2 \mathrm{I} \frac{1}{2}$ per cent. from the true volume. Thus a log which is 200 cubic feet by true measure will be $200-\left(2 \mathrm{I} \frac{1}{2}\right.$ per cent. of $\left.2 \mathrm{co}\right)=200-43=$ I 57 cubic feet by quarter-girth measure over bark. To make a bark allowance deduct 16 per cent. of this, thus volume by quarter-girth measure under bark is $157-(16$ per cent. of 157$)$ $=157-25=132$ cubic feet. In the same way the true volume of a log over bark is obtained from the volume by quartergirth under bark, by adding 53 per cent.; thus a log whose 
volume by quarter-girth under bark is 100 cubic feet has a true volume over bark of I 53 cubic feet.

For ordinary work by the square-of-quarter-girth method it is not necessary to work out the figures, because prepared tables, such as those compiled by Hoppus, are used.

No tables are given in this book because useful cards, in convenient form for the pocket, are obtainable for a few pence.

If the tree is measured over bark it is usual to make an allowance for this, but the amount varies in different parts of the country. The most usual is half an inch for any quartergirth up to 12 inches, with an extra half-inch for every additional six inches of quarter-girth for oak and other roughbarked trees. Thus if a $\log$ has a quarter-girth of ro inches over bark, its quarter-girth under bark will be taken as $9 \frac{1}{2}$ inches, while if it is 16 inches over bark it will be taken as $I_{5}$ inches under bark, and then the calculation of volume will be made as before. This allowance is equal to a reduction of 16 per cent. on the total volume of wood and bark, and in many cases is too much. In measuring beech in Buckinghamshire no allowance is made.

In actual practical work the measurement of felled timber proceeds as follows :-

First the length of the log is taken, odd inches being neglected, a five foot stick being the most convenient measuring instrument. The length is noted in the woodman's notebook, and the half-length is calculated and marked on the log. The girth is taken at this point with a piece of whip-cord attached to a bent wire by the aid of which it can be easily pushed under the tree. The string is withdrawn and is twice folded so that its length is then equal to $\frac{1}{4}$ of the girth. It is held up against a foot rule and its length is read off to the nearest $\frac{1}{4}$ inch below the actual length. Bark allowance is deducted from this, and the quarter-girth under bark thus obtained is entered in the notebook. Prepared tables are now used to obtain the volume, the cubic contents being looked out under 
the heading for the given quarter-girth and opposite the given length of the log.

If the log is not symmetrical but is irregular, each part of it is measured separately as if it was a different $\log$, and the volumes of the different parts are added together to get the volume of the whole tree.

Care must be taken in taking the girth to pull the string tight, though not stretching it, and to see that it goes straight round the log, as a half-inch more or less on the quarter-girth makes a considerable difference to the measurement of a long log. A tape with quarter-girth marked on the back can be used, but the string is more convenient and is even more accurate ; moreover, tapes soon get worn out if large numbers of logs are measured. Whatever method is used, all timber on the estate should be measured on the same system, as timber merchants can then rely on the figures and can fix their prices accordingly.

Branch wood and small stuff is usually measured by the cord of 128 stacked cubic feet. The converted wood is ranked up, and the number of stacked cubic feet is ascertained by multiplying together the length, width, and height of the stack. Thus in some parts of the country firewood is cut into lengths of 2 feet 2 inches and is ranked up into stacks 2 feet 2 inches wide, 2 feet 2 inches high, and 27 feet 4 inches long. Such a stack contains :-

$2 \frac{1}{6} \times 2 \frac{1}{6} \times 27 \frac{1}{3}=128$ cubic feet stacked, that is, including air.

Such a stack would contain between 60 and 75 cubic feet of solid wood, according to the size of the sticks and closeness of stacking.

When selling felled timber it is more satisfactory to measure it with the purchaser's measurer, as any difference can then be settled on the spot. Where the logs are irregular two men will seldom get the cubic contents exactly the same, and it saves future disputes if a representative of both seller and buyer measure it together. 
With regard to whether it is best to sell timber felled or standing, the chief advantage of selling it felled is that there is no difficulty in deciding the correct number of cubic feet; but the seller is rather in the hands of the timber merchants, as they know that the timber must be sold. Where the trees are sold standing the seller can postpone the sale for a year or two if the price offered is not suitable, though this should not be done more often than is absolutely necessary as the regularity of the yield is interfered with.

On the whole the method of selling the trees standing at so much per load or per cubic foot, the trees being measured when they are felled, is satisfactory. If standing trees are sold for a lump sum it is very essential that the woodman should estimate their cubic contents very carefully beforehand, so that he may know that the price offered is not outrageously low. Timber merchants have been known to offer a good price per cubic foot having previously underestimated the number of cubic feet by a very large amount.

\section{Measurement of single standing trees.}

The volume of a standing tree can only be accurately measured by taking the height to timber point with an instrument, and by climbing the tree to take the quartergirth at half this height. This, of course, can only be done for special reasons.

Under ordinary circumstances the best procedure is as follows :-

The tree is viewed from all sides, and the height of the spot up to which it is measurable is determined with a height measurer. There are several excellent instruments for taking heights now obtainable, and every head forester or woodman should be in possession of one. The author prefers Weise's hypsometer, obtainable from William Spoerhase, Giessen, Hessen, Germany, for about thirteen shillings. 
The instrument consists of a tube, $T$, with cross wires at $O$, and an eye-piece, $E$. A toothed scale, $H$, is fixed to the tube. $D$ is a movable scale with a plumb-line, $P$, attached to it. To take the height, stand at any point where the top and bottom of the tree can be seen. Then measure the horizontal distance to the tree. Fix the scale $D$ in such a way that it indicates, at the level of the scale $H$, the same number of units as there are in the distance between the observer and the tree. Thus, if the distance is 40 feet, set the scale at 40 . Look at the top of the tree through the tube, allowing the

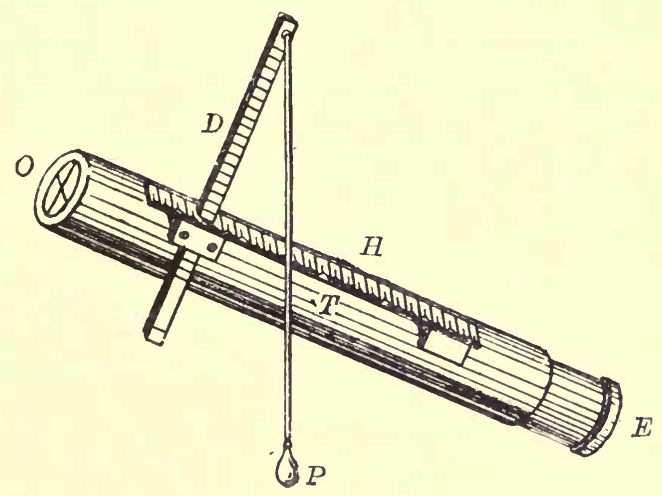

Fig. 14. Weise's Hypsometer.

plumb-line to swing clear; on getting the cross wires to coincide with the top of the tree, turn the tube gently to the right so that the plumb-line is caught in the tceth. Read off the number at this point on the scale $H$. This gives the height above the level of the observer's cye. Repeat the operation looking at the bottom of the tree. If the plumbline is now caught on the $O$ side of the scale $D$, add the result to the previous one ; if it is caught on the $E$ side of the scale, subtract the second reading from the first. The total given is the height of the tree in feet, if the unit is one foot. Where 
the tree is very high, or the distance large, the unit may be taken as two feet or a yard. Thus, if the observer is standing 90 feet away this may be taken as 30 yards, and the scale is set at 30 . The height is then obtained in yards, but as the scale is marked to show half units, the result is correct to within 18 inches.

The instrument is simple and easy to use.

The height having been obtained, the place where the half height wculd be on the tree is noted. An assistant takes the quarter-girth with a tape as high as he can reach, and the woodman estimates the fall-off in quarter-girth from this place up to half height. This is difficult to do accurately, especially on irregular trees. If the woodman has the opportunity of measuring this fall-off on large numbers of felled trees he will, however, soon be able to estimate correctly to within half an inch of quarter-girth. As a general rule, on normally shaped trees, the fall-off is about $I$ inch in quartergirth for every to feet in height for conifers, and about $I \frac{1}{2}$ inches in 10 feet with broad-leaved trees. Taking these figures as a basis the woodman must add or deduct from them according to the shape of the tree.

Having thus measured the length and estimated the quartergirth at half height, the cubic contents are worked out as for felled trees, using tables, and making the usual bark allowance if the volume under bark is required.

When large numbers of trees are to be measured singly it would be tedious to take the height of each tree with an instrument; the work can be hastened without losing much accuracy by using a pole, say 20 feet long, with feet marked on it. This should be propped against the tree, and the woodman can then estimate the length of timber above the top of the pole. Such a pole will be quite sufficient for short trees, but with tall ones the estimate should be checked periodically with the height measurer. After a little practice the length will be obtained with a very fair degree of accuracy. 
Beginners, when using a pole, usually underestimate the height.

Having found the volume of each tree, the volume of the wood is obtained by adding all the volumes together.

The calculation of the volume of woods by estimating each tree singly is a very difficult piece of work, and any great degree of accuracy can only be obtained by constant practice, and by comparing the estimates continually with the actual measurement when felled. This method should only be adopted where the method to be now described is impossible; that is, in woods where the trees are of all sizes, and are branched and irregular, as we find the standards over coppice or trees in very open woods of any kind.

Branch wood is seldom estimated, but if there are very large branches, an estimate may be made of those on one side of the tree. All should not be included, as some are likely to be broken in the fall of the tree.

For small branches the most satisfactory procedure is to cut a small area and to ascertain the outturn per acre, or this may be obtained from the results of previous fellings. Thus, if an acre of oak wood is cut and gives an outturn of 600 feet of timber, 12 cords of pit-wood, and 9 cords of fuel, it may be assumed that in similar woods the same outturn of pit-wood and fuel will be obtained per acre.

\section{Measurement of standing woods.}

Wherever woods which have grown up fairly densely, so that all the trees are more or less of the same height and shape, are to be measured, the work can be done far more quickly than by estimating the volume of each tree separately. Nearly all middle-aged plantations, especially of conifers, can be measured as follows.

The method is based on the proved fact that all trees, in a well-grown fairly dense wood, which have the same diameter 
at breast height, and the same height, will have about the same volume.

The diameters at breast height, 4 feet 3 inches from the ground, are found by using callipers made of wood, which are marked with inches and decimals of an inch. These can be easily prepared by any estate carpenter at a small cost. The

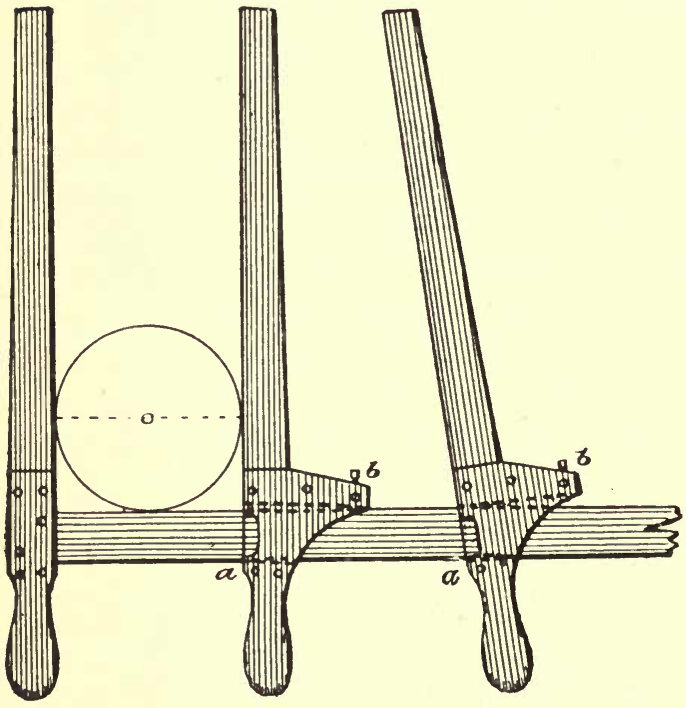

Fig. 15. Friedrich's Calliper.

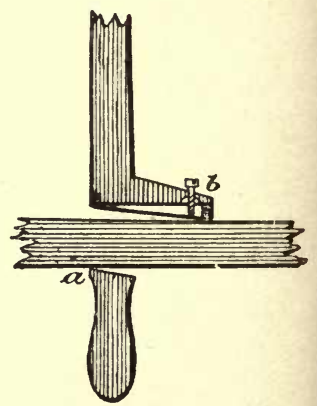

Vertical Section of Movable Arm.

instrument consists of a rule with two arms at right angles to it, one placed at the end being fixed, while the other is movable. The movable arm is pushed towards the end of the rule till the tree to be measured can be clasped between it and the fixed arm. The diameter can then be read off to a tenth of an inch. Where large numbers of trees are to be measured the work can be done far quicker by taking the diameter with callipers than by taking the girth with a tape. 
Where a single tree is measured two diameters at right angles should be taken, and the average between the two is the diameter of the tree. This is necessary, as trees may be, and often are, larger in diameter in one direction than they are in another. Where large numbers of trees are measured the average is obtained by measuring each tree in a different direction, the first being taken say north and south, the next east and west, and so on. By doing this, about half the trees will be taken on the long diameter and the other half on the short diameter, and no great inaccuracy will be obtained in the total volume of the wood.

When measuring whole woods it is not necessary to take the diameter accurately to the tenth part of an inch. All trees between $7 \frac{1}{2}$ and $8 \frac{1}{2}$ inches diameter are taken as 8 inches; all between $8 \frac{1}{2}$ and $9 \frac{1}{2}$ as 9 inches, and so on; this reduces the work, and it is found in practice that doing this makes no perceptible difference to the volume of the wood, as there will be about as many trees from $8 \frac{1}{2}$ to 9 inches as there are from 9 to $9 \frac{1}{2}$, and the average diameter of all the trees from $8 \frac{1}{2}$ to $9 \frac{1}{2}$ will in fact be practically 9 inches. There are several slightly different ways of measuring a wood when using callipers, but the most convenient for the woodman for all ordinary purposes is as follows.

A party of three or more men work up and down the wood, taking narrow strips at a time. One man books the measurement, the others take the diameters of all the trees, with callipers, calling out the result to the booker. The calliper men should place a chalk mark on each tree as it is measured to prevent its being taken again, all chalk marks being made on the side of the tree which will be visible when they return on the next strip. The booker enters the trees in his notebook, as they are called out, as follows :- 


\begin{tabular}{|c|l|l|c|c|}
\hline $\begin{array}{c}\text { Diameter at } \\
4^{\prime} 3^{\prime \prime} \text { in inches }\end{array}$ & Larch & Oak & $\begin{array}{c}\text { Total } \\
\text { Larch }\end{array}$ & $\begin{array}{c}\text { Total } \\
\text { Oak }\end{array}$ \\
\hline 6 & HH HH II & III & 12 & 3 \\
7 & HH HH HH II & IIII & 17 & 4 \\
8 & HH HH HH III & HH I & 18 & 6 \\
9 & HH HH II & HH III & 12 & 8 \\
10 & HH II & HH & 7 & 5 \\
II & III & II & 3 & 2 \\
\hline
\end{tabular}

A separate column is provided for each species which is to be measured. The totals are filled in when the whole wood is finished.

The calliper men must take care to keep their callipers up to breast height and should read off the diameter while the calliper is on the tree. The booker should repeat the figure as he enters it, to prevent mistakes. The work can be done with only one calliper man, but the booker can keep up with two men and sometimes with three or four. If an extra man is available he can keep a general look-out to see that no trees are omitted.

Each diameter class is called an inch-class. When the totals for each inch-class have been made out, a sample tree of exactly the right diameter is found for each inch-class. This should be a tree of average height, and of good shape. It is sometimes difficult to find a tree of exactly the size of the inch-class if this is left to the end, and the author has found it preferable to choose these sample trees while the callipering 
is going on. When the calliper man finds a tree whose diameter is exactly $6,7,8$, or 9 inches, or whatever the diameter of the inch-class may be, he calls out to the booker, who examines the tree, and if it seems a good average one it can be marked at once, so that it will be easily found again. A good way to mark it is to pin a large piece of white paper to it. When a sample tree has thus been found, the booker places a cross in his note-book against that inch-class to indicate that no further sample tree is required for that class. By doing this carefully, sample trees will have been found for each inch-class by the time that all the trees have been measured. If this method is carried out it is necessary to ascertain the average height of the inch-classes beforehand with an instrument. Then as each sample tree is found its height is taken and compared with the average. If very different in height the tree is not chosen.

The sample trees are cut down and each is carefully measured by the ordinary square-of-quarter-girth method as already described. Bark allowance can be made at the same time. The volume of each inch-class is now worked out by multiplying the volume of the sample tree by the number of trees in the inch-class, and the volume of the whole wood is ascertained by adding together the volume of all the inch-classes.

The following example illustrates the method. The figures are those obtained on one acre of larch wood aged sixty-five years in the Tintern woods and were measured by the School of Forestry, Forest of Dean. The wood was afterwards cut and the measured felled timber came to practically the same amount.

The following are the details of the sample trees felled, and measured by square-of-quarter-girth with the usual bark allowance. The trees were measured down to 3 inches diameter at the thin end.

It will be noticed that the trees were somewhat thin, but were of great length. 

Diameter
at $4^{\prime} 3^{\prime \prime}$
in inches.

\begin{abstract}
Length of timber.
\end{abstract} measurable
Quarter-girth under bark in middle, in inches.

Volume of tree in cuhic feet and inches. Ft. In.

$\begin{array}{rrlrr}6 & 40 & 3 \frac{1}{4} & 2 & 11 \\ 7 & 54 & 3 \frac{3}{4} & 5 & 3 \\ 8 & 60 & 4 \frac{1}{4} & 6 & 8 \\ 9 & 55 & 4 \frac{3}{1} & 8 & 7 \\ 10 & 60 & 5 \frac{1}{2} & 12 & 7 \\ 11 & 62 & 6 & 15 & 6 \\ 12 & 68 & 6 \frac{1}{2} & 19 & 11 \\ 13 & 70 & 7 & 23 & 9\end{array}$

* This tree was evidently not a good sample tree, as its length of useful timber is less than it should be.

The following figures show how the volume of the wood was ascertained.

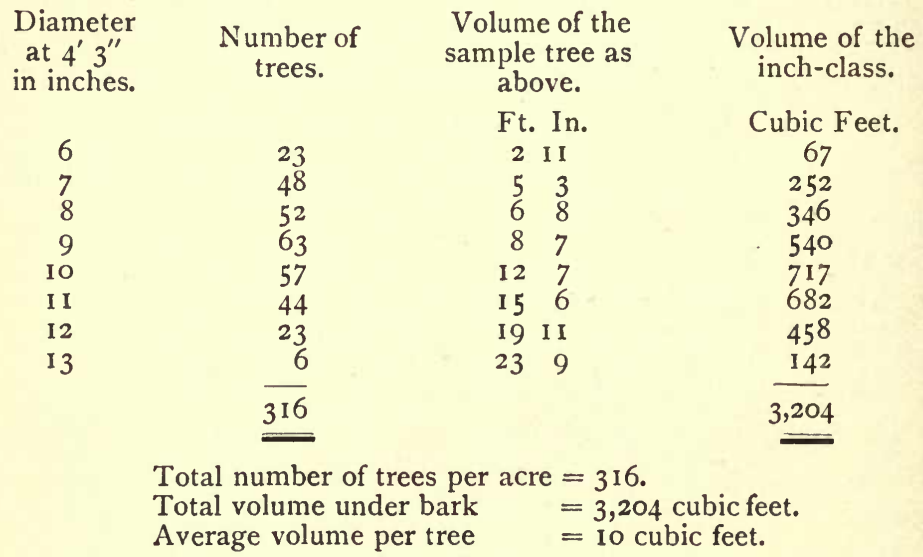

If it is impossible to find a sample tree of exactly the size of the inch-class, one as near as possible must be chosen and cut. In this case a slight allowance must be made in the volume of the sample tree. Thus, if a 9-inch tree cannot be found, but one 9.2 or 9.3 inch is found and cut, its volume may be reduced by I cubic foot before the calculation of the volume of the inch-class is made. In the same way, if a tree 8.8 or 8.7 is found, its measured volume may be increased by from 
a half to one cubic foot. The inaccuracy thus introduced will not be great.

Should the true measure be required, then it is only necessary to measure the sample tree by true measure instead of by the square-of-quarter-girth. Again, if the timber is only saleable down to 6 inches diameter at the thin end, the sample tree should be measured down to this point.

The accuracy of the method depends on finding sample trees of average height and of exactly the same diameter at breast height as the inch-class, and in careful measurement of their volume. There are other methods of measuring whole woods in which it is not so necessary to find sample trees of exact size, but as these methods involve a good deal of mathematics usually beyond the knowledge of the ordinary woodman, they are not described here. They will be found fully explained in Schlich's Manual of Forestry, Volume III. 


\section{CHAPTER XV \\ WORKING PLANS}

IN order to do away with all haphazard working, and to arrange for a regular outturn so that an approximately equal revenue will be obtained year after year, the general lines of treatment must be decided for a long period, usually one rotation of the crop. The compiler of the working plan decides the method of treatment which will be most suitable, and lays this down in a working plan report in such a way as to enable the forester in charge to know exactly what work is to be done each year; the report is accompanied by maps which show the present state of the crop, the division of the forest, and the proposed arrangement of the fellings.

Although the general lines of treatment are determined for a rotation, the actual details are laid down only for a short period, generally ten years. At the end of this period the plan is revised and the details for the next ten years are then decided.

A very small area cannot be managed so as to give an equal annual revenue, and hence no working plan is necessary for such a wood. It is managed solely according to sylvicultural rules, the woodman carrying out each year, or at regular intervals, the work which should be done to improve the crop.

All large woods should be worked according to the prescriptions of a plan; otherwise there will be no continuity in working and no system; there will be no assurance that the woods are not being either over or under felled, and the outturn, and coincidently the revenue, will rise and fall irregularly. It is obvious that the main axiom of forestry-not to remove annually from a wood more than that wood can annually produce-cannot with certainty be adhered to unless it is 
ascertained what this figure of production is. Moreover, since most woods are not normal or in their best possible condition of production, the working plan must arrange to bring about a condition of normality and this will almost certainly lead to an increased outturn and to a revenue higher than that obtained at the present time. A normal forest is one fully stocked and consisting of a complete series of growths of all ages from the seedling to the mature tree, each age class occupying equal areas, and in which the growth is proportionate to the fertility of the soil.

The annual production of a normal forest depends on a large variety of circumstances and it can only be approximately ascertained, but at any rate a working plan can guarantee that the outturn shall rather rise than fall by preventing excessive or greatly deficient felling.

As the whole future of the forest depends on the compiler of the plan, an expert must prepare it. A woodman will not be called upon to do this work, but he ought to know what a working plan means, and he may at times be called upon to collect the data, and to assist the expert.

A working plan is divided into two parts, the first being an account of past and present conditions, the second containing the prescriptions for future working. These parts are divided into a number of heads such as are given below, but all of them will not be required in every case, while exceptionally other additional heads may be necessary.

\section{Part I. Past and Present Conditions}

I. Description of the Area.

Configuration and situation.

Underlying rock and soil.

Climate.

2. Composition and Condition of the Woods.

Distribution and area.

Boundaries. 
General description of the forest growth.

Injuries to which the crops are liable.

3. Management and Utilization.

Past and present system of management.

Past revenues and expenditure.

Markets and lines of export.

Prices obtainable for produce.

Cost of extraction and supply of labour.

The staff employed.

4. Miscellaneous.

The legal position; rights and privileges.

Data as to growth and outturn.

Part II. Future Management

1. Objects of management.

2. Considerations upon which the plan is based.

3. The method of treatment.

Choice of species.

Rotation and felling cycles.

Sylvicultural system.

4. Allocation of working circles, felling serics, and annual felling areas.

5. The Felling Prescriptions.

Main fellings.

Thinnings.

Cleanings.

6. Sowing and Planting.

7. The Yield.

8. Supplementary Prescriptions.

Roads and rides.

Buildings and wells.

Saw Mills and mechanical means of transport.

Alterations in the forest staff.

Provisions for collection of statistics.

9. Financial Forecast. 


\section{APPENDICES}

I. Maps: small scale to show working circles or stock or both; large scale to show annual felling areas or stock or both.

2. Detailed description of the woods.

Part I can be mostly prepared from records in the estate office or elsewhere, and from a careful inspection of the woods. The results of this inspection are placed in an appendix where they will constitute a useful record of the state of the woods as they were at the time the working plan was prepared. This field work may very likely be allotted to the woodman. The woods are taken in detail and are divided up for the purpose of description into moderate-sized areas, each such area being called a compartment. These compartments, it should be understood, have nothing directly to do with the working circles or with the felling areas eventually prescribed; they are purely for purposes of description. There is no necessity to mark the boundaries of compartments on the ground, provided they can be picked up from the map, but it is often useful to eventually so mark them by erecting small squared wooden pillars at all corners, the number of the compartment facing each side of the pillar being painted on it. When this is done it enables anyone having work in the woods to find any particular spot. Compartments should usually be of moderate size, from 10 to 40 acres, but this depends on the local conditions.

The boundaries are, if possible, fixed on natural features, separate woods, ridges, roads, rides and so forth, the main point being convenience of description. In some parts of the forest the condition of the crop, the soil, the aspect, or other factor may vary within quite restricted areas and this will necessitate small compartments. In another part there may be a large area of 100 or 200 acres covered with exactly the same type of forest, and the whole can then be placed within one compartment. Thus the compartments need not be equal in size. They are numbered from I upwards, one 
series running through the whole forest, and proceeding in succession across the ground, compartment 20 being next to compartment $2 \mathrm{I}$ and so on.

The description itself, besides being a record, is also referred to by the compiler of the plan when allocating the felling areas, as to do this he must know exactly what the stock and conditions are like at all points of the area dealt with. The description must, in fact, present a complete picture of the area, and notes should be made on the following points.

r. Climate. Elevation above the sea, aspect, slope, exposure to strong or dry winds, the degree of exposure to frost.

2. Soil. The underlying rock, mineral composition, depth, degree of porosity, degree of moisture, surface covering.

3. Growing stock. Method of treatment in the past, species, density, age, height, volume estimated or measured, quality.

DESCRIPTION OF

\begin{tabular}{l|c|c|c}
\hline Name of block. & $\begin{array}{c}\text { No. of } \\
\text { compartment. }\end{array}$ & Area. & Situation and climate. \\
\hline Copes & & $\begin{array}{l}\text { On a slope with westerly } \\
\text { aspect. Elevation } 300 \text { to } \\
500 \text { feet. Rather exposed } \\
\text { to westerly gales. }\end{array}$ \\
\hline Beechenhurst & I3 & $\begin{array}{l}\text { On a slope with north-west } \\
\text { aspect. Elevation 400 to } \\
\text { foo feet. Sheltered from } \\
\text { gales and not frosty, except } \\
\text { in the lower part. }\end{array}$ \\
\hline
\end{tabular}


In addition notes regarding future treatment may be useful, the following points being taken into consideration. Whether the wood requires underplanting; any cleaning, pruning, or thinning required; whether the wood should be finally felled, and if so, what species should be grown and whether it should be sown, planted, or naturally regenerated. Any special measures necessary for protection against fire or other dangers ; any roads or draining necessary; any improvement of the boundaries possible.

These notes are usually made by the compiler as a guide, though the future treatment can only be decided after the full description of the area has been completed.

For the field work the note-book should be divided up as follows, and by way of explanation sample descriptions are given :-

Compartments

Soil and surface covering.

Deep good sandy loam over Millstone grit. Surface clean in most parts with brambles and fern in the more open places.
Fairly good sandy loam over Coal measures. Surface covered with fern and brambles.

\section{Description of crop.}

Fine growth of oak standards $100-140$ years old, 70 to 80 feet high, about 40 trees to the acre with good clean stems. Estimated volume 3,000 cubic feet per acre.

Pure beech coppice about 25 feet high, dense. Young oak and ash here and there in the coppice.

Poor growth of oak about I 00 years old, 50 trees to the acre, height 50 feet ; estimated volume 800 cubic feet per acre. Here and there in the more open spaces are groups of larch 12 years old, 15 feet high.
Notes regarding future treatment and remarks.

Cut away beech where endangering the young oaks or ash. "Otherwise leave the wood alone to grow on.

Right of way from $\mathrm{X}$ to $\mathrm{Y}$ as marked on the map.

Clear cut all the oaks leaving the larch. Plant up with groups of larch, Douglas fir, and Scotch pine, in order to obtain a crop which can be cut for pit-wood in 50 years. 
Under Part I is a head for data of growth and outturn. In most woods such figures will not be available when a plan is first prepared, but the plan may provide for the collection of such statistics, which would be of great value when it is revised in the future; the woodman may be entrusted with the work. The rate of growth in cubic contents per acre is roughly ascertained from the results of a number of measurements made, in the way already described in Chapter XIV, at intervals of five years, throughout specially marked off areas known as 'growth measurement' or ' sample' plots. If such measurements are made at regular intervals in woods of different ages, the compiler will be able to judge approximately what amount of timber will be added to a wood in any given number of years, and he will also get some idea of the 'possibility' of the forest. The possibility is the maximum quantity of material which may, for the time being, be annually removed from a forest consistently with such treatment as shall tend to bring the forest as near as possible to the normal state, and with maintaining a constant yield.

In some plans the compiler fixes the outturn by volume only, laying down that so many cubic feet are to be cut every year, and in this case he must ascertain the possibility in cubic feet. The first estimate can be constantly corrected as time passes, and experience is gained from results. In other plans the above detail is not entered into, and the possibility is merely one by area governed by sylvicultural conditions. This will usually be the case at present in British working plans, the area to be cut each year being laid down; the possibility in this case is the annual yield, or the volume which can be obtained from the area cut annually. This is ascertained by measuring the standing crop in the compartments to be felled, or from the results of previous cuttings in similar woods.

The woodman will find no difficulty in understanding all that is written in a plan under the remaining heads in Part I. 
Part II is the plan proper. It may be extremely complex, but it will be prepared by the compiler, and only a few points need be considered here in order to enable the woodman to understand the reasons of the prescriptions laid down.

In the first place it has to be considered what the object aimed at is. For example, it might be that the woods were required to supply pit-props, or to meet some special industry - such as that of the wheelwright, the chair-maker, or the clogmaker-or large timber may be aimed at, or a part may be required for shooting coverts, and so forth.

Next the special circumstances of the property have to be considered, for example, the presence or absence of a saw-mill, a line of rail, a wharf, a canal, these affecting the disposal of the produce. Again, the woods may be unusually exposed, or at a very high altitude. In short, a hundred different circumstances may have to be taken into consideration when deciding the form the plan shall take and the method of treatment to be prescribed.

The aim and circumstances being known, the species to maintain or to introduce can be settled, and the sylvicultural method of treatment decided. With this are naturally connected the rotation and felling cycles. This is usually the most important part of the plan.

Then the compiler considers where the markets lie, and decides how many working circles are required. Each working circle is divided into the number of felling areas, sometimes called 'coupes', corresponding to the years of the felling cycle, and the compiler decides upon the arrangement of these felling areas, possibly forming several felling series. When settled, the working circles and felling areas have to be plotted on the large-scale map and the acreage worked out.

Some further explanation appears desirable regarding this division of the forest into working circles and felling series. 
Working circles.

A working circle is a wood, or part of a wood, which, at the end of the rotation, will contain a complete series of age classes. Thus, in a wood with a total area of 500 acres, and a rotation of 50 years, if an equal area is cut each year there will be, at the end of the rotation, 50 ten-acre blocks covered with woods varying in age from 50 down to I year old, as shown in the following diagram.

\begin{tabular}{|c|c|c|c|c|c|c|c|c|c|c|}
\hline & 46 & $4 \mathrm{I}$ & 36 & $3^{I}$ & 26 & $2 I$ & 16 & I I & 6 & I \\
\hline & 47 & 42 & 37 & 32 & 27 & 22 & 17 & 12 & 7 & 2 \\
\hline \multirow{3}{*}{$\begin{array}{l}\text { Wind } \\
\text { direction. }\end{array}$} & 48 & 43 & 38 & 33 & 28 & 23 & I8 & I3 & 8 & 3 \\
\hline & 49 & 44 & 39 & 34 & 29 & 24 & 19 & 14 & 9 & 4 \\
\hline & 50 & 45 & 40 & 35 & 30 & 25 & 20 & I5 & 10 & 5 \\
\hline
\end{tabular}

The area marked I is the first area cut, and at the end of the rotation it will have 50-year-old trees upon it. Such a wood forms one working circle. The total area of $5 \mathrm{co}$ acres need not form a compact block; blocks say of 100, 200, and 200 acres respectively can be included in one working circle.

One circle is usually sufficient where the area is not large, and where the crop is of such a character that the whole forest can be managed on one system.

In the following cases, especially in large woods, it will be necessary to divide the forest into two or more circles.

I. If the woods contain two species with different rotations, growing in pure woods; for instance, if part contains conifers on a 50-year rotation, and the rest broad-leaved trees on a rotation of 120 years.

2. If two or more parts of a wood are to be managed on different systems; for instance, if part is coppice-withstandards and the rest is high forest with clear cutting.

3. If it is necessary to have cuttings in two or more parts of the forest at the same time. This will usually be the case 
in extensive woods; for instance, there may be a regular demand for timber at two ends of an estate, and two cutting areas will be necessary each year, so as to supply the purchasers without forcing them to go long distances.

4. Even if the whole forest can be managed on one system and rotation, it may be necessary to have two or more circles, so as to reduce the cutting area in one spot to a workable size. Thus, if 50 acres are to be cut each year, it may be better to cut 25 acres in one place and 25 in another than to have the whole 50 acres cut in one large block. This arrangement also facilitates supervision, as the whole work will not be in the charge of one woodman. The workmen also may not have to go so far to their work.

5. In conifer woods it is desirable to have small felling areas in order to reduce danger from insects. This is ensured by having several working circles.

Where there are two circles, both worked on a 50-year rotation, the arrangement of the cutting is somewhat as follows :-

Working Circle $B$.

Working Circle $A$.

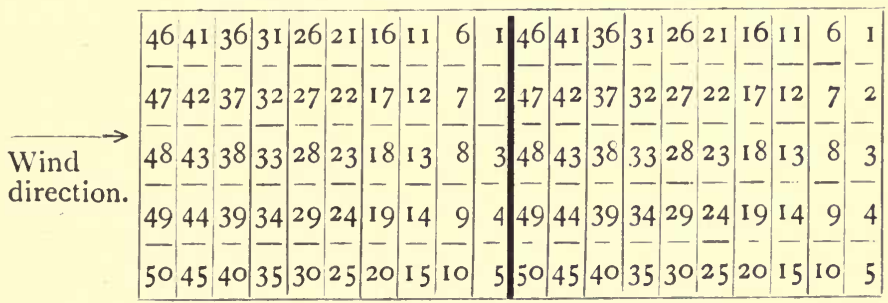

In each year both the areas with the same number will be cut. At the end of the rotation each circle will have a complete series of age classes.

Each circle need not form a compact block as in the diagram; for instance, all the existing conifer woods on an estate, wherever they are situated, may be placed together into one circle, and all the broad-leaved woods into another. 
Very few high forests in England have anything approaching a proper series of age classes, and it is often the main object of the compiler to obtain it as soon as possible.

\section{Felling Series.}

Where the woods consist wholly of broad-leaved trees, or of a mixture of conifers and broad-leaved trees, the working circle need not be divided. But in extensive pure conifer woods there is danger of serious damage by insects if a felling is made adjoining an area cut within the last three or four years, which is stocked with a young plantation. To avoid this the working circle is divided into several felling series, and a felling is made in a different one each year, so that the crops in a series vary by a fixed number of years. Thus, if it is decided that three full years should elapse before a cutting is made next to a previous one, the working circle is divided into four series $A B C D$, and the fellings proceed as indicated in the following diagram.

Felling Series $C$. Felling Series $A$.

\begin{tabular}{|c|c|c|c|c|c|c|c|c|}
\hline & 15 & I I & 7 & 3 & \multirow{2}{*}{$\frac{13}{29}$} & \multirow{2}{*}{$\frac{9}{25}$} & \multirow{2}{*}{$\frac{5}{2 I}$} & \multirow{2}{*}{$\frac{1}{17}$} \\
\hline & 31 & 27 & 23 & 19 & & & & \\
\hline & 47 & 43 & 39 & 35 & 45 & $4 \mathrm{I}$ & 37 & 33 \\
\hline \multirow{3}{*}{$\begin{array}{l}\text { Wind } \\
\text { direction. }\end{array}$} & 16 & 12 & 8 & 4 & 14 & IO & 6 & 2 \\
\hline & 32 & 28 & 24 & 20 & 30 & 26 & 22 & I 8 \\
\hline & 48 & 44 & 40 & 36 & 50 & 42 & 38 & 34 \\
\hline
\end{tabular}

Felling Series $D$. Felling Series $B$.

It will be seen that the working circle will contain, at the end of the rotation, a complete series of age classes as before, but these will not follow each other regularly over the area. The felling series need not be marked on the ground, but, in 
order that there may be no danger of windfall, each series should be separated from the next by a broad ride, as the ride-side trees then become storm-firm and are not so easily blown down when the wood lying to the windward is cut. If the woods happen to be in several isolated blocks, each may form a separate series, or two or more small blocks may be included in one series.

After deciding upon the working circles and felling series the compiler lays down the felling prescriptions, which will follow the sylvicultural method of treatment adopted. There may also be special prescriptions not directly following the lines of a well-known method of treatment, and such would be given in full detail. In locating the annual felling areas the compiler takes into consideration the direction in which the felling should proceed. This is usually from the north-east or east of each block towards the south-west or west, as this is in the opposite direction to the prevailing winds. By proceeding thus, danger from windfall is reduced and young plantations are formed behind the shelter of standing woods. Directly following the felling prescriptions come the instructions for sowing and planting. The yield will be estimated from such data as are available, and into this matter will come questions of possibility by area, possibility by volume, possibility by number of stems, and so on, which are connected with the method of treatment adopted. Without going into this subject it will be sufficient to say that the compiler of the plan must arrange that the yield is so checked that excessive felling is impossible, while insufficient cutting is avoided, for this too would be an error.

The supplementary provisions are instructions concerning roads, buildings, staff, or any such matter. Finally, it is desirable to form an estimate of the future revenue and expenditure. 


\section{CHAPTER XVI}

\section{THE USES OF BRITISH TIMBER}

\section{BROAD-LEAVED TREES}

Alder. Cigar-boxes, clog-soles, barrel-staves, broom-heads, toys; the charcoal is used for making gunpowder. It is well suited for use underground and in water.

Ash. Coach-building, furniture, stamping hammers, wheelwright's work, joinery implements, tool and whip handles, billiard cues, racquets, hurdles, barrel-hoops, gymnastic apparatus, lance-shafts, rudders and oars, thatchwood for stacks, and for any purpose where toughness and elasticity are required.

Beech. Chair-making, bent-wood furniture, for floors and staircases, stamping hammers, railway-sleepers, street pavingblocks, pianofortes, carpenters' benches, wheelwright's work, agricultural implements, calico-mill rollers, packing-cases, sieve-frames, wooden shoes, gun-stocks, broom-heads, brushbacks, handles of planes, chisels and other tools, boot-trees.

Birch. Joinery, cabinet-making, furniture, wheelwright's work, barrel-staves, crates, turnery, wagon-making, carving, brush-backs, clogs, brooms, spools and bobbins.

Elm. Furniture, coffins, coach and wagon building, turnery, wheelwright's work, butchers' blocks, inner lining of ships, keels of boats, tin-plate boxes.

Common elm timber is more valuable than that of wychelm.

False Acacia. Wheelwright's work, especially spokes, and for motor-car wheels, rungs, treenails, tool-handles, gate and fence posts, turnery. 
Hazel. Hoops, sieve-frames, walking-sticks.

Hornbeam. Wheelwright's work, cogged wheels and other woodwork in machinery, turnery, shoemakers' pegs and lasts, plane-boxes, carpenters' benches, tool-handles, agricultural implements, pulley-blocks, and all small articles where great toughness is required.

Horse-chestnut. Sides and bottoms of carts, cabinet-making, turnery, reels and bobbins.

Lime. Carving, founders' models, used under veneer, wooden basket-work, pianofortes and organs, wooden shoes.

Mountain Ash. Spoke and shaft wood.

Oak. Superstructures, hydraulic works, bridges, ship and boat building, house-building and interior decorations, gateposts, mill wheels, railway-sleepers, mining timber, joiner's work, cabinet-making, carriage-building, wheelwright's work, blocks, staves, bungs, sieve-frames, shingles, treenails, woodcarving, pianoforte making, turnery, window-frames, park palings, hurdles, rungs for ladders, cask-staves.

The timber of sessile oak is softer and more easily worked than that of pedunculate oak, and is preferred where great strength is not essential. Pedunculate oak is the best for all work of construction.

Poplar. Framework for veneered furniture, wheelwright's work, packing-cases, bottoms and sides of carts, brake-blocks for railway carriages, cigar-boxes, matches, pulp for paper. Aspen is preferred for matches and pulp for paper.

Sweet Chestmut. Interior work in house-building, furniture, gate-posts, park palings, fences and hurdles, staves, hop-poles, hoops.

Sycamore and Maple. Furniture, turnery, carving, reels and bobbins, churns and other dairy utensils, box-making, musical instruments, gun-stocks, whip handles, bread platters, wooden spoons, clog-soles, blocks of pulleys, calico-mill rollers.

Walnut. Cabinet-making, gun-stocks, veneer, wood-carving, turnery. 
Willow. Framework for veneered furniture, packing-cases, hurdles, bottoms and sides of carts, bread platters, knife-boards, cricket-bats, basket-work, clothes-pegs, withies.

Service Tree, Apple, Pear, and Cherry. Cabinet-making, turnery, carving, printers' tools, veneers.

\section{CONIFERS}

Austrian and Corsican Pine. Used for the same purposes as Scotch pine, but the wood of both is coarser and less durable.

Douglas Fir. Used for the same purposes as larch, but the timber is not of the same quality.

Larch. Telegraph and telephone posts, railway-sleepers, bridges, boats, cart-making, masts, fencing, pit-wood. Larch of all sizes is useful, and is one of the most durable of British timbers. It is much used for all estate work.

Scotch Pine or 'Red Deal'. Used for similar purposes as larch, but it is not so durable: it is also used for scaffolding, and house-building.

Spruce or 'White Deal'. House-building, for rafters and boarding, furniture, masts, telegraph posts, scaffolding and ladders, packing-cases, boxes, toys, cask-staves, musical instruments, pit-wood, wood pulp, fencing.

Silver Fir or 'White Pine'. Used for similar purposes as spruce.

Weymouth Pine or 'Yellow Pine'. House-building, especially in roofs, packing-cases, cabinet-making. It is very light in weight.

Yew. Bows, cabinet-making, wood-carving, turnery. 


\section{INDEX}

Accommodating spec:es, 33 .

Alder, notes on, I 48.

Animals, protection against, 108.

Annual rings, 13 .

Anther, 14 .

Aphis on beech, 124 .

on larch, 123.

on spruce, 122.

Arboriculture, definition of, 7 .

Armillarea mellea, 129.

Ash, notes on, 149.

Aspect, influence of, 22.

Austrian pine, notes on, 171 .

Banks' pine, 173.

Bark, structure of, 12 .

Bast, 12.

Beech, notes on, 150.

seedling mildew, 137 .

woolly aphis, 124 .

Beetles, 115 .

Birch, notes on, 151 .

Birds, classification of, II I. protection against, $\mathbf{I} \mathbf{I}$.

Bole, 7 .

Bordeaux mixture, I 37.

Broad-leaved tree, definition of, 16. trees, notes on, 148 .

Callipers, description of, 198 .

Calyx, I4.

Cambium, II.

Carpels, 15.

Cembran pine, notes on, 173 .

Chermes abiet is, 122.

laricis, 123.

Cherry, notes on, 152.

Chestnut, sweet, notes on, 159. horse, notes on, I 54.

Chlorophyll, 8.

Choice of species, points to consider, 19.
Cleaning, 73 .

Clear cutting method of treatment, 85.

Climate, effect of, 18.

Cluster pine, notes on, 172 .

Coccus fagi, 124 .

Cockchafer, II 5.

Coleophora laricella, 120.

Compartment method of treatment, 88.

Compartments, description of, 207. Conifer, definition of, 17.

Conversion of coppice-with-standards, 105.

Coppice, definition of, 84 . shoots, 16. system, 98 .

Coppice-with-standards, definition of, 84 .

system, 100.

Cork cambium, 12.

Cork, formation of, 12.

Corolla, I4.

Corsican pine, notes on, 171 .

Crack willow, notes on, 162 .

Cypress, large-coned, notes on, 164.

Lawson's, notes on, 164 .

Dasyscypha calycina, 133 .

Depth of soil, 30.

Dicotyledons, 13.

Dioecious species, 16.

Dominated trees, definition of, 75 .

Dominating trees, definition of, 75 .

Douglas fir, notes on, 165 .

Drainage, 184 .

Drought, 139 .

Elevation, effect of, 2 I.

Elm, notes on, 152.

Exacting species, 33. 
False acacia, notes on, 148.

Felling of timber, 187 .

Felling series, 214.

Fences, wire, $18 \mathrm{I}$.

Fencing, 177 .

Fertilization, 15 .

Final cutting in natural regeneration, 92.

Fire, protection against, 143 .

Flowers, I4.

Fomes annosus, 131.

Food of a tree, 8.

Formation of mixed woods, 38 .

Frost crack, 138 .

effect of, 23.

lifting, 139 .

protection against, 25 .

Fruit, 15.

Fungi, 127.

Game coverts, 103.

Girdling, effect of, 9 .

Group method of treatment, 95 .

Growth in height, 38 . in thickness, II.

Gymnosperms, 13 .

Hares, 108.

Hazel, notes on, 153 .

Heartwood, 12.

Hedges, 177.

Height growth, 38 .

High forest, 83 . two-storied, 87.

Holly, notes on, 154 .

Honey fungus, 129.

Hornbeam, notes on, 154 .

Horse-chestnut, notes on, 154 .

Humus, definition of, 29. effect of, 33.

Hylobius abietis, 116.

Hyphae, 128.

Hypsometer, description of, 195.

Imago, I 12.

Insects, life-history of, I I I.

pievention of attack by, II 3 .

remedial measures against,

I 14 .

Japanese larch, notes on, I69.
Laburnum, notes on, 155 .

Larch aphis, 123.

canker, 133.

Japanese, notes on, 169.

miner-moth, 120.

notes on, 168.

sawfly, 122 .

Larva, I I I.

Latitude, effect of, $2 \mathrm{I}$.

Lawson's cypress, I64.

Leaf-canopy, 8.

Lenticels, 10.

Light, 26.

demanding spccies, 27.

Lime-tree, notes on, I 55.

Locust-tree, notes on, ${ }_{4} 8$.

Lophyrus pini, I 21.

Maple, Norway, notes on, 160.

Maritime pine, notes on, 172.

Measurement of felled timber, I 89.

of standing trees, 194.

of whole woods, 197 .

Medullary rays, 14.

Melampsorella Caryophyllacearum,

132.

Melolontha vulgaris, 115.

Methods of treatment, 83 .

Mice, I09.

Mineral composition of soil, 29.

Mixed woods, 36 .

advantages of, 36 .

disadvantages of, 38 .

formation of, 38 .

Moisture in the soil, 31 .

Monocotyledons, 13 .

Monoecious species, 16 .

Moths, IIg.

Mountain ash, notes on, I 55.

Mountain pine, notes on, 173 .

Mycelium, 128.

Myelophilus piniperảa, II 8.

Natural regeneration, 89 .

Nectary, I 4.

Nectria ditissima, 136 .

Nematus Erichsoni, 122.

Nordmann's fir, notes on, 167.

Normal forest, 205.

Notch planting, 68. 
Number of plants per acre, 65 . of trees per acre, 78 .

Nurseries, 48.

area of, 50.

choice of site for, 49 .

formation of, 50.

laying out of, 52 .

manuring of, $5 \mathrm{I}$.

pricking out, 57 .

quality of seed, 56 .

sowing seed-beds, 52 .

tending of, 59 .

Nursery management, 47.

Nurses in plantations, 45 .

Oak leaf-roller moth, I I9. pedunculate, notes on, 156 . sessile, notes on, 157 . Turkey, notes on, I 57 .

Objects of the owner, 19 .

Osier, notes on, 163 .

Ovary, 15.

Ovules, 15.

Paraffin emulsion, II4.

Parasites, 128.

Partial clearance, 79 .

Peridermium pini, I 32.

Petals, I 4.

Peziza Wilkommii, 133.

Photosynthesis, 8.

Phytophthora omnivora, 137.

Pine beetle, I 8 .

blister, 132.

sawfly, I 2 I.

weevil, 116.

Pistil, 15.

Plane, notes on, 157.

Planting, $6 \mathrm{I}$.

cost of, 70 .

density of, 64 .

methods of, 67 .

season for, 62 .

Plants, age and size of, 61 .

distribution of, in planting, 63 .

lifting of, 62.

number of, per acre, 65 .

pruning of, 58 .

purchase of, 48 .

raising of, in nurseries, 49 .

Pollen grains, 14 .
Polyporus sulphureus, I 36.

Poplars, notes on, 158 .

Porosity of the soil, $3 \mathrm{I}$.

Possibility, definition of, 210.

Preparatory cutting in natural regeneration, 91.

Protection against-

animals, I08.

birds, I I O.

frost, 25,138 .

fungi, I27.

insects, III.

storms, 140.

weeds, 125 .

Protoplasm, II.

Pruning of young plants, 58. of trees, 80.

Pupa, I I 2.

Purchase of plants, 48.

Pure woods, $36,46$.

Rabbit fencing, 183 .

Rabbits, 108.

Red Cedar, notes on, 164 .

Red-rot root fungus, I 31 .

Remarkable pine, 173.

Reproduction, I4.

Respiration, Io.

Rotation, 83 .

Sallow, notes on, 162 .

Saprophytes, 128.

Sapwood, 12.

Sawflies, 121.

Scale insects, I 22.

Scientific names of species, 19.

Scotch pine, 169.

Seed, age at which produced, 95.

beds, 52 .

dispersal of, 16.

sowing, 52.

testing of, 56 . quality of, 56 .

Seeding cutting in natural regeneration, $9 \mathbf{I}$.

Selection method of treatment, 97.

Sepals, I4.

Shade-bearing species, 28.

Silver fir canker, 132.

notes on, 167 . 
Soil, depth of, 30 . effect of, on tree growth, 29. examination of, 35 . improving species, 34 . porosity of, $3 \mathrm{I}$. moisture in, 31 .

Soils, classification of, 29.

Sowing in the forest, 60 . season for, 57 .

Species, list of, 19.

Spruce gall aphis, I 22.

Norway, notes on, 174 .

Sitka, notes on, 175 .

Squirrels, Iog.

Stagheadedness, 42.

Stamens, I4.

Starch, formation of, 8 .

Stigma, I 5.

Stomata, Io.

Storms, 140.

Struggle for existence, 74.

Style, 15.

Sugar, formation of, 8.

Suppressed trees, 75 .

Sycamore, notes on, I6o.

Sylviculture, definition of, 7 .

Sylvicultural systems, 83 .

Tending of woods, 73 .

Thinning, 73 .

advantages of, 74 .

of mixed woods, 76 .
Tortrix viridana, II 9.

Trametes radiciperda, 131 .

Transpiration, Io.

Tulip-tree, notes on, I6I.

Turkey oak, notes on, I 57.

Two-storied high forest, 87 .

Underplanting, 43.

Uses of British timber, 216.

Voles, 109.

Walls, 184 .

Walnut, notes on, I6I.

Weeding, 69.

Weeds, 125 .

Weymouth pine, notes on, 172 .

White alder, notes on, 149. ash, notes on, 150.

Willows, notes on, 162 .

Wind, protection against, 26, I 40.

Winged seeds and fruits, 16.

Wire fences, $\mathrm{I} 8 \mathrm{I}$.

Witches' broom, 133.

Wood, structure of, 12 .

Woods, tending of, 73 .

Working circle, 212.

Working plans, 204 .

Wych-elm, notes on, 153 .

Yew, notes on, 175 . 





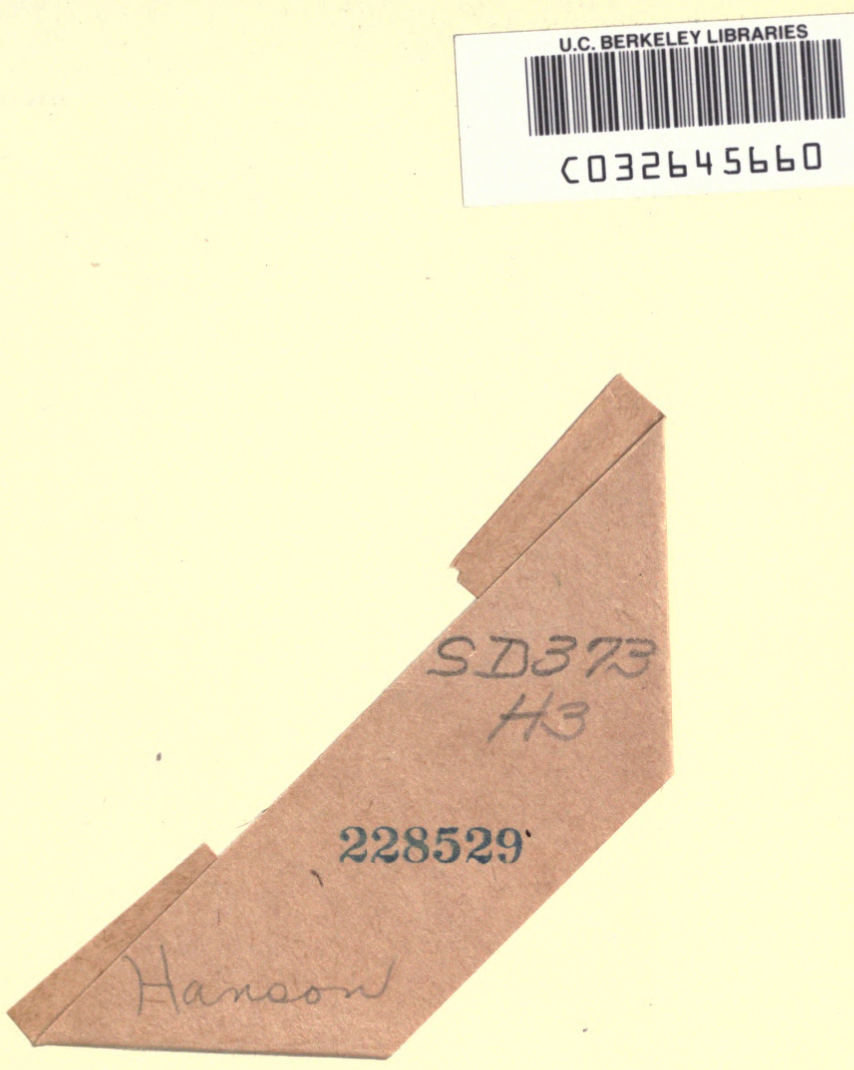
